\title{
LA PALABRA FINGIDA Y LA DEMOCRACIA DELIBERATIVA
}

Régimen de verdad y discursos parlamentario y periodistico en un contexto de Reforma Constitucional.

Estudio sobre los discursos parlamentario y periodístico, acerca de los Derechos Indígenas, como régimen de verdad, en el contexto de Convención Constituyente de 1994, en la Provincia del Chaco

Autora: Gabriela María Nery Sosa Director: Dr. Jorge Próspero Rozé 


\section{Índice}

Presentación de la investigación y palabras claves...................................ág.1

Capítulo I: Estado del Arte.........................................................Pág.2

Prensa gráfica y análisis del discurso............................................Pág.3

Marcos cognitivos y contexto.....................................................ág.5

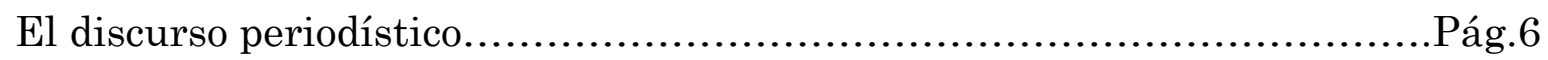

La producción periodística......................................................ég.8

La técnica periodística: la jerarquización de la noticia........................Pág.9

Contextos: trayectos históricos y sociales del periodismo....................Pág.11

El discurso parlamentario/ constitucional: Creador de principios y de

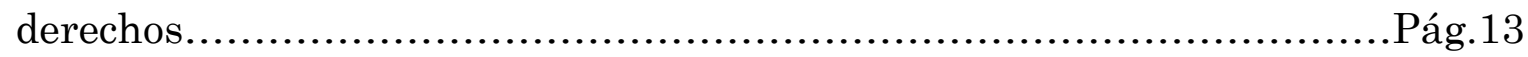

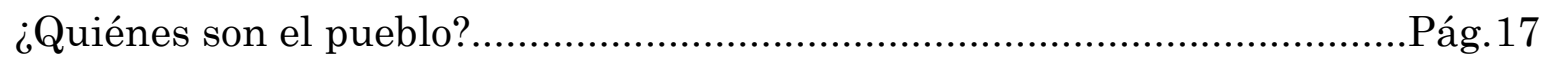

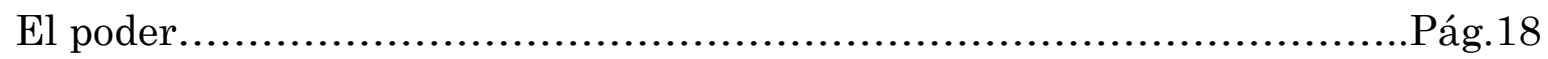

Capítulo II: Objeto de estudio, objetivo general y objetivos específicos.....Pág.20

Capítulo III: Fundamentación..................................................Pág.21

Capítulo IV: Propuesta teórico metodológica..................................Pág. 26

Capítulo V: Desarrollo analítico...............................................Pág.27

Matriz comunicativa y la asignación o el orden del nombrar................Pág.27

Régimen de verdad y régimen discursivo: Las Constituciones como género

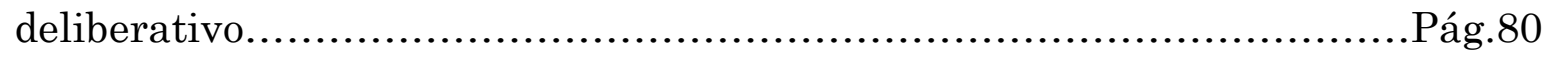

Derechos indígenas como modelización discursiva en el discurso parlamentario

Pág.92

Prensa gráfica chaqueña....................................................ág.142

Capítulo VI: Reflexiones analíticas originales

La palabra fingida: Discursos parlamentario, periodístico, régimen de verdad y poder. .Pág.156

Bibliografía..... Pág.165 


\section{a-Título: La palabra fingida y la democracia deliberativa. Régimen de verdad y discursos parlamentario y periodístico en un contexto de Reforma Constitucional.}

b- Tema: Estudio sobre los discursos parlamentario y periodístico, acerca de los Derechos Indígenas, como régimen de verdad, en el contexto de Convención Constituyente de 1994, en la Provincia del Chaco

\section{Palabras claves: Discurso y régimen de verdad}

Discurso y régimen de verdad, en el marco del proyecto presentado, son solapas de un mismo proceso, en términos de Foucault. Discurso debe ser entendido como un texto que se agota en su aspecto lingüístico y que debe ser interpretado como “en cierto modo, como juegos (games), juegos estratégicos de acción y reacción, de pregunta y respuesta, de dominación y retracción, y también de lucha. El discurso es ese conjunto regular de hechos lingüísticos en determinado nivel, y polémicos y estratégicos en otro" (Focault:1980). Esta noción discute la definición de símbolo, característica de la escritura, de la lingüística de Saussure, que remite una "cosa", del orden del mundo natural, al signo convencional que la nombra, denominado símbolo, en este caso, palabra. Este orden convencional, entre el signo de orden natural y el signo/símbolo que nombra, entre denotación y connotación, interpretado desde la semiótica estructuralista, como una relación de sentido, es discutido por Focault como una relación de poder, a la que añade "los mensajes, los mensajeros que envía y que deben regresar, justificarán su vinculación con el poder porque cada uno de ellos posee un fragmento de la pieza que se combina perfectamente con los demás. Los griegos llaman a esta técnica jurídica, política y religiosa fumbolon: el símbolo”. Por verdad, debe entenderse "un conjunto de procedimientos reglamentados por la producción, la ley, la repartición, la puesta en circulación, y el funcionamiento de los enunciados. La «verdad» está ligada circularmente a los sistemas de poder que la producen y la mantienen, y a los efectos de poder que induce y que la acompañan. «Régimen» de la verdad. (Foucaut: 1980). 


\section{c- Estado del Arte}

La presente investigación integró los estudios sobre el análisis crítico del Discurso, en términos de Van Dijk:

“Uno de los desarrollos nuevos del estudio discursivo está representado por el creciente interés en el análisis del contexto. Este desarrollo debe verse en oposición al trasfondo representado en la concepción crecientemente multidisciplinar del análisis del texto y del habla en la mayoría de las ciencias humanas y sociales. Hoy ya no es adecuado examinar solamente las estructuras 'lingüísticas' del discurso 'en sí mismo', ni siquiera limitarse uno mismo a las estructuras autónomas de interacción de la conversación, sino que es necesario buscar más allá del discurso y examinar sus ambientes cognitivo, social, político, cultural e histórico",

En el artículo "LA CONTEXTUALIZACIÓN DEL DISCURSO PARLAMENTARIO: AZNAR, IRAQ Y LA PRAGMÁTICA DEL MENTIR”, Van Dijk postula la necesidad de atender a los contextos societales. Por ello, a los fines de este trabajo, se encontró que esos contextos congnitivos, sociales, políticos, etc., significativos para los actores participantes de la Convención Constituyente de 1994, se vinculaba no solo a ese acto comunicativo, sino a todos los actos comunicativos anteriores que seguían concatenando cadenas significativas y eran re-actualizadas en el discurso parlamentario. Por ello, se analizaron las Convenciones de 1853, 1951(Chaco); 1957 (Chaco) para interpretar las matrices comunicativas en el acto de nombrar la provincia del "Chaco", "pueblos indígenas/derechos indígenas" y sus implicancias comunicativas y performativas respecto del debate constitucional que dio origen al artículo 34Derechos indígenas, y sus relaciones con la Tierra Pública, en términos de derecho positivo.

El Régimen de la Tierra Pública en la Argentina es un tema de debate en constante tensión. Desde la constitución del Estado Nación hasta el gobierno neoliberal de 2016.

La vigencia del tema en debate se evidenció en el decreto y la noticia sobre la intervención del gobierno del Presidente Mauricio Macri- en julio de 2016- para 
"flexibilizar controles", que permitían conocer los nombres de los propietarios de las tierras argentinas ${ }^{\mathrm{ii}}$.

Ese ejemplo justifica de la inclusión del análisis del contexto (R-C, nomenclatura de Van Dijk) para poder hacerlo comprensible, en términos de análisis crítico de discurso: sus implicancias y consecuencias sociales.

El contexto "se concibe como el 'ambiente explicativo" del discurso. De esta manera, en un debate parlamentario, el contexto puede limitarse al marco general de las Cortes españolas, cuando los diputados están presentes, y algunos otros factores obvios que nos dan categorías textuales, pero, ¿qué pasa con 'contextos' tales como la situación del país en ese momento, o la situación internacional, o la política exterior española, etc.? La mayor parte de tales ambientes pueden muy bien ser relevantes al estudio de tal discurso, pero la pregunta es también sobre si dichos ambientes son en realidad relevantes para los propios hablantes del parlamento. De aquí que los contextos generalmente estén limitados a los aspectos relevantes del ambiente,"iii.

El ambiente explicativo se encontró en el análisis de la noticia, en el análisis del decreto y en el análisis de sus implicancias políticas- sociales- económicas.

Así también las Constituciones tienen sus normas de escritura, en el texto constitucional, y sus argumentaciones, en Convención. Se comprenden con el análisis del debate, de la norma establecida, de la prensa gráfica (en el presente estudio) y con la genealogía de las matrices comunicativas que operan como marcos cognitivos y sociales.

\section{Prensa gráfica y análisis del discurso}

Se reconocieron diferentes líneas teóricas, perspectivas y abordajes para el estudio de la prensa gráfica: el análisis textual de las noticias, por ejemplo, en su superficie redaccional, las relaciones entre enunciados y, por otro, el estudio del las noticias y el contexto social- político-económico, sus propósitos pragmáticos. Sobre el estudio de las noticias como parte del proceso de producción de sentido social, dieron cuenta los trabajos publicados por la Universidad Nacional de La Plata $^{\text {iv. }}$ 
En la compilación, editada por Sanucci (2004) se trazaron itinerarios sobre las relaciones entre la prensa gráfica, las identidades y la comunicación política, su "pertenecer y estar situado", como comprensión de la matriz de pensamiento que impera en una sociedad, en un momento histórico determinado y así también con relación a la/s forma/s del Estado, como una configuración de relaciones de poder, entre clases o fracciones sociales, a través del análisis del diario Clarín ${ }^{\vee}$

Otro aporte acerca del rol social de los medios, en la producción de sentido, es la definición de los periódicos como sistemas de interacción, como lo expresan Mar de Fontcuberta y Héctor Borrat ${ }^{\mathrm{vi}}$.

La Universidad Nacional del Comahue, en julio de 2004, presentó una investigación que analizaba el desarrollo histórico del diario Río Negro, medio de referencia dominante de la Patagonia, con su rol en la historia de la provincia.

El trabajo "Estrategias de delimitación de espacios discursivos específicos en la prensa argentina de circulación diaria- radicado en la Secretaría de Ciencia y Tecnología de la UNR, de docentes-investigadores de distintas cátedras del Departamento de Ciencias de la Comunicación y por un grupo de adscriptos y pasantes, analizó "las diferentes estrategias discursivas de constitución de las diversas secciones temáticas de la prensa escrita de circulación diaria en espacios discursivos tensionales dotados, por una parte, de características propias y de funcionamiento relativamente autónomo y sostenidos, por otra, en regularidades inherentes tanto al periódico que las acoge como al texto de prensa en general. A partir de este análisis, se busca evaluar si la constitución de estos espacios, según modalidades específicas, participa o no -en alguna medida- en la tarea de construcción de imaginarios y representaciones sociales propia de la prensa escrita en sociedades mediatizadas"vii

El estudio de las estructuras y estrategias argumentativas, concebidas como el resultado de la elección previa de un punto de vista, que los medios de comunicación españoles emplearon en la caracterización de los actores sociales implicados en los sucesos de El Ejido viii, también buscó entender en un contexto particular las relaciones entre discurso y sociedad.

El lenguaje configura un modelo de mundo y da cuenta de las condiciones de producción y de recepción de los textos, las relaciones sociales: las luchas entre fracciones sociales, las relaciones con el Estado, las luchas por el poder. 
Siguiendo a Van Dijk, estos trabajos comparten una perspectiva crítica: "El análisis crítico del discurso es un tipo de investigación analítica sobre el discurso que estudia primariamente el modo en que el abuso del poder social, el dominio y la desigualdad son practicados, reproducidos, y ocasionalmente combatidos, por los textos y el habla en el contexto social y político. El análisis crítico del discurso, con tan peculiar investigación, toma explícitamente partido, y espera contribuir de manera efectiva a la resistencia contra la desigualdad social" (Van Dijk: 1999).

\section{Marcos cognitivos y contextos}

Ahora bien, una verdad no es verdad sin que la proposición que postula sea aceptada como tal. Los periódicos son actores relevantes (Borrat: 2006) en el complejo sistema de construcción de creencias.

"Más allá de su tarea de mediadores entre una imagen de la realidad ofrecida como un período consistente, el presente social y su público (Gomis, 1991) los medios se han convertido en las agencias centrales de producción simbólica de las sociedades contemporáneas (Pinto 2003). No solo ofrecen información sino pautas y modelos de comportamiento. Permeabilizan nuestras vidas lo queramos o no, seamos conscientes o no"ix

Su interacción con las élites es otra de las tantas tramas de relaciones, estrategias y tácticas, "games" en los que circula el poder.

En términos de presentación en géneros y formatos, "la estrategia de la escritura periodística establece, un pacto de lectura: aunque parezca increíble lo que se cuenta, es un acontecimiento totalmente real, lo opuesto de lo que se supone literario"

Estas proposiciones consideradas verdaderas, en el discurso periodístico, son las crónicas. Vinculadas entre sí por relaciones de coherencia, hacen creíbles los modos de presentación de los temas, van representando y construyendo un modo de "leer" e interpretar la realidad.

Otra relación relevante es la de las crónicas y sus contextos, en este caso, el contexto de la reforma constitucional. "Hoy ya no es adecuado examinar solamente las estructuras "lingüísticas" del discurso "en sí mismo", ni siquiera limitarse uno mismo a las estructuras autónomas de interacción de la 
conversación, sino que es necesario buscar más allá del discurso y examinar sus ambientes cognitivo, social, político, cultural e histórico"xi , expone Van Dijk. Es decir que el "estudio discursivo no debería estar limitado a un análisis "autónomo" del texto y del habla, sino que debería también desarrollar una teoría del contexto “. Estas consideraciones surgen del estudio sobre "La contextualización del discurso parlamentario: Aznar, Iraq y la pragmática del mentir", a partir del cual Van Dijk explica que "contexto no debería estar formulado en términos de situaciones objetivas sociales o incluso de sus propiedades relevantes, sino más bien en términos de las modelaciones mentales: las modelaciones contextuales. Tales modelaciones representan las definiciones subjetivas de la situación comunicativa y controlan la contribución de cada participante a la interacción. Además, las categorías normales de las situaciones sociales, tales como el Marco y los Participantes (y sus identidades, roles, relaciones, etc.), modelaciones contextuales, también deberían caracterizar los aspectos cognitivos de la situación, tales como los propósitos y el conocimiento de los participantes. Especialmente el conocimiento de los participantes es crucial en el manejo de la información que queda implícita y de lo que está siendo hecho explícito, recordado o supuesto en el discurso. El Recurso-C de las modelaciones contextuales hace justamente eso: controlar tácticamente el conocimiento en la interacción. Tales tácticas son también cruciales para el manejo de las mentiras". Este modo de interpretación, supone también que el debate parlamentario no solamente puede ser analizado en términos generales del contexto, sino que debe analizarse más específicamente como una forma de interacción política (Van Dijk: 2004)

\section{El discurso periodístico}

El discurso periodístico es una práctica social de producción de información en un sistema social, político y económico. "La producción de información es 1) una actividad compleja que se realiza, 2) de forma industrial, 3) en el seno de una institución reconocida socialmente "xii.

A continuación, el análisis de cada aspecto significativo del concepto:

1) una actividad compleja 
Es una actividad compleja porque la búsqueda de información implica seleccionar ciertos temas, según ciertos criterios. Es decir, la información requiere de alguien que la detecte, la presente y la cuente. Y ese relato no está exento de intereses, juicios previos, ideas y propósitos pragmáticos.

\section{2) de forma industrial}

Es industrial porque involucra un proceso de producción, basado en ciertas rutinas periodísticas. Hay formas de producción periodística que se esperan de los periodistas y que se aprenden en la socialización del trabajo cotidiano.

\section{3) en el seno de una institución reconocida socialmente}

La institución reconocida socialmente es el sistema mediático, con sus distintos medios: diarios, TV, radio, multimedia. Es reconocida socialmente, porque solo a los medios, la sociedad asigna el papel de construir el acontecer, la actualidad, la información, la noticia.

Tradicionalmente en el estudio de la noticia se consideró al periodista como un mensajero y a los medios como transmisores de información. Justamente, esa hipótesis está en serio entredicho, por los argumentos expuestos.

La objetividad periodística opera como mito, donde se asocian significados como “independencia", o que "no está influido por algo o alguien externo a los hechos" sobre los cuales el periodismo da cuenta.

Se discutió la objetividad entendida como constitutiva del objeto, es decir del acontecimiento. Esa noción parte del supuesto que hay una realidad dada, "natural", sobre la cual hay que informar y que existe per se, autónoma de la producción social de sentido de los sujetos. Cuando la idea de objetividad se asocia a este significado, decimos que estamos ante el mito de la objetividad periodística.

El término mito suele ser empleado de "manera amplia y variada para referirse a la forma que tiene una cultura de comprenderse, expresarse y comunicarse conceptos importantes respecto de su autoidentidad como cultura". Se define también, desde ciertas concepciones antropológicas, como "una narrativa compuesta de manera anónima que ofrece explicaciones por qué el mundo es como aparenta ser y por qué las personas obran como lo hacen. (...) Presenta sus explicaciones como si estas fueran universales o naturales". Desde algunas corrientes semióticas, "denota una cadena desarticulada de conceptos asociados, en virtud de los cuales los miembros de una determinada cultura entienden ciertos 
temas. (...)El mito opera de manera no conciente e intersubjetivamente. Es asociativo y no narrativo (...) Su función primaria es hacer natural lo cultural"xiii Entonces, (aunque los enfoques mencionados son diferentes entre sí) hay coincidencias respecto de que el mito intenta presentar como natural la cultura de una sociedad. Ofrecer una explicación simple sobre fenómenos complejos.

\section{La producción periodística}

"Para que existan relaciones de producción que caracterizan a las sociedades capitalistas, es preciso que existan, además de ciertas determinaciones económicas, estas relaciones de poder y estas formas de funcionamiento del saber. Poder y saber están sólidamente enraizados, no se superponen a las relaciones de producción pero están mucho más arraigados que aquellos que los constituyen" (Focault: 1978).

En tal sentido, la producción periodística forma parte de las relaciones de producción, de las más relevantes: las simbólicas y preserva también todo un conjunto de técnicas orientadas a producir un tipo de discurso social: el de la prensa.

Se inicia con un acontecimiento. "Pero no hay que entender el acontecimiento como algo ajeno a la construcción social de la realidad (...) Es decir que los acontecimientos estarían formados por aquellos elementos exteriores al sujeto, a partir de los cuales este mismo va a reconocer, a construir el acontecimiento. Así pues, podemos dejar sentadas las siguientes premisas:

1. Los acontecimientos se generan mediante fenómenos externos al sujeto.

2. Pero los acontecimientos no tiene sentido al margen de los sujetos, ya que son éstos los que le dan el sentido.

3. Se da una relación de inclusión, por la que los fenómenos externos percibidos por el sujeto se convierten en acontecimientos por la acción de éste sobre aquellos. Los acontecimientos están compuestos por los caracteres de los elementos externos a los que el sujeto aplica su conocimiento". En síntesis este punto refiere a la objetivación y a la interiorización. 
El primer punto afirma que los acontecimientos son fenómenos externos al sujeto. Es decir, existen, no son inventados por ellos aunque sí son expresados en géneros $\mathrm{y}$ formatos al ser publicados.

Para diferenciar el acontecimiento de la noticia, hay que considerar que: "El acontecimiento es un mensaje recibido, mientras que la noticia es un mensaje emitido. Es decir, el acontecimiento es un fenómeno de percepción del sistema, mientras que la noticia es un fenómeno de generación del sistema. Sin embargo, lo que para un sistema son noticias, para otro sistema son acontecimientos"xiv El acontecimiento se transforma en noticia al pasar por un embudo conformado por los criterios de selección del medio y de los periodistas, según sus valores explícitos y/o implícitos-, a través de una operación de selección, que implica una relación de inclusión/exclusión. Es importante aclarar en cuanto a los valores, que los que tienen mayor incidencia en la producción periodística no son los valores del periodista, sino los de la organización informativa.

Las noticias de todos los diarios no son idénticas en su tratamiento, aún cuando se generaron en un mismo acontecimiento o, también podemos distinguir que algunos acontecimientos se transforman en noticia para un medio y otros no. "Los mass media utilizan como materia prima los acontecimientos sociales y, a su vez, son productores de noticias que se van a convertir en acontecimientos sociales" ${ }^{\mathrm{xv}}$ Entonces, el primer paso para que un acontecimiento se convierta en noticia es haber sido seleccionado por alguien (medios/periodistas)

La primera fase del proceso de producción periodística, es por tanto, la selección del acontecimiento. En la elección de los acontecimientos que serán noticia tienen una gran incidencia los criterios de la organización productiva (medio) al que pertenece un periodista e incluso prima sobre sus propios criterios personales.

La relación inclusión/exclusión fue trabajada en la presente investigación al momento de analizar el discurso periodístico.

\section{La técnica periodista: La jerarquización de la noticia}

Jerarquizar es ordenar de mayor a menor grado de importancia la información. Se habla de jerarquía porque no se alude a una lista de temas, sino al orden que pone en relieve lo importante de lo poco relevante o de lo principal y lo secundario. Este orden se aplica sobre datos (principales y secundarios) en una nota. También 
regla la composición gráfica de la página o la tapa. Lo primero va cabeza de página y lo secundario más abajo. Al igual que para designar la información que va en las primeras páginas y dentro de éstas a su vez, en las páginas impares.

Es decir, la primera forma de entender qué es importante para un medio es el orden jerárquico de la información. Empezando por la tapa y siguiendo las demás secciones y también en la estructura de cada nota.

La estructura jerárquica facilita al lector la comprensión de los temas, que infiere a "través de los titulares, las cabeceras y las proposiciones respectivas; en tanto el autor ya conoce al menos los principales temas y debe expresarlos, señalarlos y rellenarlos". (...) Una de las características más llamativas y típicas de la realización o elaboración temática del discurso periodístico es su carácter "troceado". Es decir, cada tema se presenta en partes, no como un todo, como es el caso de otros discursos. Esta característica estructural tiene su origen en el principio global de la organización de la relevancia en la noticia. Este principio sostiene que el discurso periodístico se organiza de manera tal que la información más importante o relevante se pone en la posición más destacada, tanto en el texto tomado como un todo como en las oraciones. Esto significa que para cada tema, la información más importante se presenta primero. Cuando la información importante de otros temas ya se ha presentado, los temas anteriores se reintroducen con detalles de menor nivel. De esta manera, en lugar de una realización izquierda-derecha de los temas a partir de una estructura temática, tiene lugar una realización arriba-abajo, si esta organización arriba- debajo de lo general a lo particular también coincide con la dimensión importante-menos importante (lo cual no es siempre el caso: a veces un detalle semántico puede tener mayor relevancia que la proposición de nivel más alto que quizá la haya subsumido"xvi

En el discurso periodístico hay reglas de especificación, entendida como detalle de ciertas características o cualidades de algún objeto. Se produce en dos ciclos: las especificaciones de alto nivel se dan primero (la información abstracta, descripciones detalladas a la identidad y características de los participantes, la acción, el momento, etc.) y luego siguen los detalles de nivel más bajo.

Estos conceptos permitieron distinguir el uso de la técnica periodística en los diarios estudiados. 


\section{Contexto: Trayectos históricos y sociales del periodismo}

Dijo Foucault "lo que distingue al lenguaje de todos los demás signos y le permite desempeñar un papel decisivo en la representación no es tanto que sea individual o colectivo, natural o arbitrario, sino que analice la representación según un orden necesariamente sucesivo: los sonidos, en efecto, sólo pueden ser articulados uno a uno; un lenguaje no puede representar al pensamiento de golpe, en su totalidad; es necesario que lo disponga parte a parte según un orden lineal. Ahora bien, éste es extraño a la representación. Es verdad que los pensamientos se suceden en el tiempo, pero cada uno forma una unidad, ya sea que se admita, con Codillac, que todos los elementos de una representación son dados en un instante y que sólo la reflexión puede desarrollarlos uno a uno, ya sea que se admita con Desttut de Tracy que se suceden con una rapidez tan grande que no es prácticamente posible observarla y retener su orden.

(El lenguaje) No se opone al pensamiento como el exterior al interior o la expresión a la reflexión; no se opone a los otros signos- gestos, pantominas, versiones, pinturas, emblemas- como lo arbitrario o lo colectivo a lo natural sino como a todo esto como lo sucesivo a lo contemporáneo. Es, con respecto al pensamiento y a los signos, lo que el álgebra respecto a la geometría: sustituye la comparación simultánea de las partes (o de las magnitudes) por un orden cuyos grados han de recorrerse unos a otros. En este sentido el lenguaje es el análisis del pensamiento: no un simple recorte, sino la profunda instauración del orden en el espacio $^{\text {xvii”, }}$

El discurso periodístico, como cualquier discurso, instaura un orden. La naturaleza de ese orden, y su análisis ético, corresponde a otro plano. Más bien esta definición, además de filosófica, intenta relacionar el modo de conocer humano y el modo de representarse en el lenguaje.

Es por ello que, escribir puede ser también una mentira y una simulación. Escribir es también crear personajes. Siguiendo a Van Dijk, la pragmática del mentir no es potestad única de las Cortes españolas o de Aznar.

La libertad de expresión era, en la Grecia antigua, potestad de los hombres libres, que eran los ciudadanos en condiciones de portar armas, que podían participar de la asamblea. Estas asambleas eran territorios de disputa política y de poder. 
Las asambleas limitaban el ejercicio de poder de los gobernantes. El poder de designar implica también el poder de vetar.

Se conjetura que la libertad de expresión tenía como fin limitar el poder del representante. Sólo a partir de la instauración de la idea del monoteísmo, la fuente del poder terrenal pasó a ser una divinidad única, con decisión absoluta sobre los destinos humanos.

De esta fuente se alimentaron las monarquías posteriores que existían por "ungimiento" de Dios.

La preocupación central de los ciudadanos griegos era que el gobernante no se transformase en un tirano, Y un tirano, en ese sentido, era un traidor a su clase social. Rebajar tributos y ganarse el apoyo del pueblo, era ser un tirano, porque con el apoyo de ese pueblo se doblegaba a las castas dirigentes, para instaurar el dominio de un solo dirigente.

Cuando el cristianismo se transforma en religión oficial, da fundamento a los reinados de la Edad Media. Dios en la tierra, tenía sus delegados y eran los príncipes, con derecho absoluto sobre la propiedad y las decisiones.

Varios siglos después, otro de los hitos en la lucha por limitar el poder absoluto, fue la invención de la imprenta, contemporánea al descubrimiento de América. Estos y otros hechos, cuya complejidad se omite por razones prácticas, cuestionaron a la Iglesia, y pregonaron la libre interpretación de la Biblia, que pasó de ser un documento restringido a un documento de circulación pública, entendida como pública a los que tuviesen las competencias de la lectura y la escritura que no eran la mayoría.

La reforma es el primer cisma de esa creencia y la República de Crowmell uno de sus hitos fundacionales.

Pero lo llamativo es que la lucha por la libertad se restringía en cuanto la facción revolucionaria llegaba al poder. Crowmwell no escatimó sangre de adversarios y tribunales de ajusticiamiento a ningún opositor.

Se podría aventurar la idea que la libertad de expresión era una proclama revolucionaria, que, en cuanto tomaba el poder la facción revolucionaria comenzaba a operar algún tipo de control social, que volvía a encorsetar tal libertad.

La libertad de expresión era necesaria para la lucha por el poder, pero una vez conquistado éste, entraba en tensión. 
Los periodistas de las Américas del siglo XIX fueron modernistas, Martí, Rodó, Sarmiento. Creyeron en el periodismo como una herramienta de concientización y de educación. Asimilaban el rol del periodista al de un maestro.

Antes, los filósofos franceses, Montesquieu, Voltaire, Rousseau y los llamados libertarios ingleses Milton, Locke, se ocuparon de este asunto. Proclamaron la necesidad de libertad y racionalidad y defendieron el derecho de la libre expresión, cuando aún el concepto de "noticia" tal cual lo conocemos hoy era inexistente. Así también fueron estrictos con sus enemigos, a los que combatieron como decía Sarmiento "con la pluma y la palabra” y menos idílicamente, con las armas.

Nunca el periodismo fue territorio neutral, porque ¿cómo puede permanecer neutral un testigo de su época?, ¿Cómo puede un hombre, puesto en el deber de dar cuenta de su historia vívida, no tomar partido, por lo que considera justo o bueno?

El discurso periodístico estaba marcado por una ética y un ideal de sociedad posible. Sea La república de Platón, la Utopía de Tomas Moro, la República de Cromwell, el Contrato Social de Rousseau, el sueño de los Estados Unidos de Jefferson y Madison, la Argentina de Roca o la Argentina de Perón.

Y para dar sentido a los hechos, concurren a esa compleja operación, explica David Hume, categorías generales que llama "impresiones" e "ideas". "Las impresiones son más poderosas que las ideas; son, dice Hume, percepciones "fuertes y vívidas". Todas las ideas derivan de impresiones y están enraizadas en

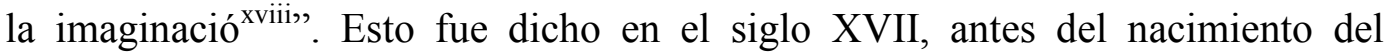
psicoanálisis y sigue mostrándose en la modernidad.

\section{El discurso parlamentario/constitucional: Creador de principios y derechos}

Siguiendo a Foucault, el origen de la verdad y sus formas jurídicas son parte del discurso social.

Se consideraron ciertos trayectos para entender la génesis del discurso parlamentario/constitucional, como tipología discursiva.

En primer lugar como una gran conquista de la democracia griega: "el derecho a dar testimonio, de oponer la verdad al poder" (Focault: 1980) 
La democracia ateniense desarrolló "formas racionales de la prueba y la demostración: cómo producir la verdad, en qué condiciones, qué formas han de observarse y qué reglas han de aplicarse (filosofía, sistemas racionales, sistemas científicos). En segundo lugar (...) desarrolló un arte de persuadir, de convencer a las personas sobre la verdad de lo que se dice, de obtener la victoria para la verdad o, aún más, por la verdad. Nos referimos a la retórica griega” (Focault: 1980)

En tanto, en el Derecho Germánico no se opone "la guerra a la justicia, no identifica justicia y paz, sino, por el contrario, supone que el derecho es una forma singular y reglamentada de conducir la guerra entre los individuos y de encadenar los actos de venganza. El derecho es, pues, una manera reglamentada de hacer la guerra"(Focault: 1980)

Posteriormente "el derecho romano se impuso al derecho germánico". Por lo cual, a partir de la Alta Edad Media, segunda mitad XII, se entendió que:"Una justicia que no es más un pleito entre individuos y libre aceptación por estos individuos de ciertas reglas de liquidación sino que, por el contrario, se impondrá a individuos, oponentes, partidos. Los individuos no tendrán en adelante el derecho de resolver, regular o irregularmente sus litigios; deberán someterse a un poder exterior a ellos, que se les impone como poder judicial y político ${ }^{\text {xix }, . ~(F o c a u l t: ~ 1980) ~}$

Así se presentó la primera noción de sistema jurídico organizado desde un poder exterior para establecer reglas y sanciones a los individuos, por medio de sistemas de representación que se darían posteriormente, a través de diversos sistemas: monarquías parlamentarias, repúblicas, etc.

Hacia finales del siglo XVIII y comienzos de XIX, Focault define la "Sociedad disciplinaria" considerando que "la infracción penal es la ruptura con la ley, ley civil explícitamente establecida en el seno de una sociedad por el lado legislativo del poder político. Para que haya infracción es preciso que haya un poder político, una ley y que esa ley haya sido efectivamente formulada.

Antes de la existencia de la ley no puede haber infracción” (Focault: 1980).

Cuando las sociedades se transformaron en económicas, "grandes sociedades y compañías se organizan como policía privada para defender su patrimonio" (Focault: 1980).

Así se define la relación entre Derecho y propiedad. 
El Derecho, siguiendo a Focault nace como un poder fuera de la subjetividad de los individuos, a los que los individuos en tanto seres sociales, deciden obedecer para resolver los pleitos, sin uso de la violencia o de la guerra.

Un sistema de regulación social y por tanto un dispositivo de control.

Ahora bien: ¿para qué es necesaria la regulación de la violencia? Siguiendo esa genealogía, sobre los territorios tomados por guerras, debía después instaurarse un sistema de reglas, donde el vencedor pactaba un trato con el vencido, a los fines de continuar asegurando el dominio sobre la propiedad y sumar fuerza de trabajo sobre esos territorios.

En principio, con los las formas jurídicas de la Edad Media (reinados, ducados, etc.); siguieron después las colonias, en el caso de América, la relación de dominación con los pueblos indígenas vencidos, a través de una organización en misiones y reservas y el uso de encomienda, conocido ya por los pueblos del Norte Argentino (en nuestros términos actuales) que habían huido del dominio del Imperio Inca. En tanto, se mantenía la guerra con las naciones indígenas que conservaban poder de su territorio y recursos para la guerra.

Las formas de sometimiento civilizatorio, son anteriores a la llegada del hombre blanco en América, con dos imperios conocidos: Azteca e Inca.

La referencia de dominio territorial y político, por cercanía geográfica, para los pueblos indígenas del Gran Chaco, fueron los incas.

Vale la pena reflexionar sobre el asunto, para no simplificar y pensar que no hubo dominio imperial en América, antes de la conquista. Es decir, existieron formas jurídicas de dominación, organizadas por la civilización incaica.

Existía pues en la memoria colectiva, la idea del dominio del territorio, las consecuencias de la guerra y el trato a los vencidos.

Citando a Rousseau "el primero al que, tras haber cercado un terreno, se le ocurrió decir "esto es mío" y encontró personas lo bastante simples para creerle, fue el verdadero fundador de la sociedad civil ${ }^{\mathrm{xx}}$ ", con esa frase del "Discurso sobre el origen de la desigualdad entre los hombres"; y siguiendo su pensamiento en el "Contrato social", los asuntos de dominio, del trato entre vencedores y vencidos, son el origen de la sociedad civil y por tanto del Derecho.

Para situarnos en las sociedades modernas, sobre los tribunales constitucionales, Habermas (1998), analizando facticidad y validez, si bien se refiere al sistema alemán, aporta rasgos a considerar. Cita a R. Alexy sobre Teoría de los derechos 
fundamentales (1993): "El discurso relativo a derechos fundamentales no está ligado a las decisiones que se toman en el procedimiento de producción legislativa, sino que queda pre-ordenado a ese procedimiento y por encima de él. Esto significa que en ese discurso falta el factor de vinculación más importante para la argumentación -profesional en general, a saber, la ley simple, relativamente concreta en la mayoría de los casos. Su lugar vienen a ocuparlo determinaciones o definiciones de los derechos fundamentales, muy abstractas, abiertas y cargadas de ideología".

Habermas, siguiendo a Hesse (1990), comparte "las decisiones del Tribunal Constitucional contienen sin duda un momento de configuración creadora. Pero toda interpretación tiene un carácter creador. Y sigue siendo interpretación aún cuando sirva a responder a cuestiones de derecho constitucional y tenga por objeto normas de la amplitud y apertura de las que son propias del derecho constitucional. La concretización de tales normas puede ofrecer mayores dificultades que la de preceptos elaborados con mucho más detalle; pero esto no cambia nada en el hecho de que en ambos casos se trata de procesos estructuralmente análogos ${ }^{\mathrm{xxi}}$,

Este análisis de Habermas se sitúa en la división de Poderes y en la actuación del Poder Judicial, cuanto en la interpretación de la norma del legislador democrático, interviene el sistema judicial, extralimitando su autoridad de aplicación de la norma. Reafirma que el poder creador es del legislador político, que es quien cuenta con la representación para legislar sobre principios y derechos, no así el sistema judicial.

Con ello advierte sobre la afectación al principio de división de Poderes, en las democracias modernas, del sistema judicial.

Es un principio de legitimidad sobre el orden de la democracia delegativa y sirve para reconocer el carácter especial del legislador político (o convencional constituyente) único designado para la creación en principios y derechos, en la sociedad moderna.

Y más adelante, veremos cómo operó posteriormente en el caso de análisis la apertura y amplitud en la norma constitucional, respecto de la entrega de tierras a comunidades indígenas, vía interpretación legislativa y decretos reglamentarios. 


\section{¿Quiénes son el pueblo?}

Para la instauración de principios y derechos, en el Estado Moderno, se aplicó el principio de democracia delegativa. ¿Quiénes son el pueblo?

Esta provocadora pregunta es formulada Ronald Dworkin, filósofo de Derecho y Catedrático de Derecho Constitucional (2013).

Coincido en que tratamos con conceptos interpretativos y de ahí su conexión con las matrices discursivas.

Inicia este interrogante, con una suposición liminar: "Un día, el Japón otorga iguales derechos de voto a los ciudadanos de Noruega para que, de desearlo, estos puedan elegir una pequeña bancada de compatriotas en la Dieta japonesa. A continuación, esta vota por mayoría la fijación de impuestos al petróleo noruego y encauza lo recaudado hacia las refinerías japonesas. Esta fantasía distaría de proporcionar el autogobierno a los noruegos. Si alguna forma de proceso mayoritario ha de resultar en un genuino autogobierno, deberá ser el gobierno de una mayoría del pueblo que corresponde.

El gobierno del pueblo que corresponde pareció más importante a más gente- a los pueblo de África luego de la Segunda Guerra Mundial, por ejemplo, o a los ciudadanos blancos del sur estadounidense con anterioridad a la Guerra de Secesión- que su papel como individuos en ese gobierno. Las personas quieren ser gobernadas por otras que sean relativamente semejantes a ellas. A menudo no está claro qué significa esto. Se ha considerado que la actitud justifica muchas formas diferentes de tribalismo o nacionalismo: de raza, religión, lengua, parentesco e incluso como en el viejo Sur, de circunstancia o interés económicos. Historiadores, estadistas y políticos no pueden ignorar el vigor de estas diversas fuerzas centrípetas: ellas siguen impulsando a la gente a la violencia más terrible. Pero no tienen una fuerza normativa intrínseca. No hay respuesta no histórica correcta a la pregunta: ¿sobre la base de qué principio debería la gente dividirse en comunidades políticas?"

(...)

"La igualdad política exige que la distribución del poder político implique una confirmación de la igualdad de consideración y respeto que la comunidad política tiene por todos sus miembros. Reservar el poder a alguna persona o grupo en función de nacimiento, el botín de la conquista o una aristocracia del talento, o 
negar los emblemas de la ciudadanía a algún individuo (excepto, tal vez, como consecuencia de un delito u otro acto contra la comunidad), es inaceptable. Pero la igualdad aritmética de influencia no es posible ni deseable, y la igualdad aritmética de impacto solo es esencial en la medida en que la desviación signifique un insulto. Por lo tanto, la igualdad aritmética de la concepción mayoritarianista no tiene en sí misma ningún valor. La regla de la mayoría no es un procedimiento de decisión intrínsecamente equitativo, y no hay nada en la política que lo haga intrínsecamente equitativo en su ámbito. No tiene necesariamente más valor instrumental que otros ordenamientos políticos. Si la legitimidad de un ordenamiento político puede mejorarse por medio de medidas constitucionales que generen cierta desigualdad de impacto pero no acarreen ninguna mancha o peligro de indignidad, sería perverso excluir esas medidas. Esa es la fatal debilidad de la concepción mayoritarianista. Esta acierta al destacar el valor de igual impacto, pero malinterpreta la naturaleza y, por ende, los límites de ese valor; compromete el verdadero valor en juego, que es la libertad positiva, al convertir la igualdad de impacto en un peligroso fetiche ${ }^{\mathrm{xxii}}$ (Dworkin: 2014)

\section{El poder}

El poder es un tipo particular de relaciones entre individuos (...) El rasgo distintivo del poder es que algunos hombres pueden, más o menos, determinar por completo la conducta de otros hombres, pero jamás de manera exhaustiva o coercitiva.

Por ejemplo: en las confesiones bajo tortura, admitidas en la política ateniense y continuada hasta los inicios de la modernidad, y proseguida en esta, pero ya fuera del orden legal, el último resguardo del individuo era la posibilidad de callar, de no delatar, confesión que en los juicios previos a la modernidad eran admitidos en los juicios. Esas confesiones eran obtenidas de forma coercitiva.

El poder al que nos referiremos, está en todas partes; no es que lo englobe todo, sino que está en todas partes. Ya no puede ser pensado sólo represiva o coactivamente, sino también activo y constructivo, en el sentido que insinúa, tienta, alienta, a través de ideales, convicciones, deseos.

El poder más que «sujetar» sujetos, los «fabrica», a través de dispositivos como la familia, la sexualidad, el trabajo, etc. (Murillo: 1997) 
"No es propiedad de algunos, sino atraviesa todo el cuerpo social, aunque con grados diferentes de concentración. El poder atraviesa todos los cuerpos y cualquiera es portador en sus intereses, deseos, actitudes, curiosidades. $\boldsymbol{E} \boldsymbol{l}$ poder

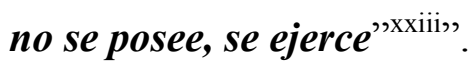

No es un conjunto de aparatos que garantizan la sujeción de los sujetos al Estado, no debe mirarse el poder en un sentido unitario sino en la dirección de micropoderes que se ejercen en el entramado de relaciones sociales y que más que operar la sujeción de un sujeto, construye activamente a esos sujetos, los fabrica.

En el presente estudio Táctica se vinculó a los efectos locales del poder, a veces conscientes y racionales. Permite a los individuos efectuar, por cuenta propia, o con la ayuda de otros, cierto número de operaciones sobre su cuerpo y su alma, pensamiento, conductas. En tanto, la Estrategia: se dibujó a partir de las prácticas como un movimiento, como una determinada relación de fuerzas y que es anónima.

La prohibición es la reducción característica. "La reducción de los procedimientos de poder en la ley de prohibición. Esta reducción a la ley juega tres papeles importantes: permite valorar un esquema de poder que es homogéneo a cualquier nivel en el que uno se sitúe y a cualquier dominio: familia o Estado, relación de educación o de producción.

Permite pensar el poder solamente en términos negativos: rechazo, delimitación, barrera, censura. El poder es aquello que dice no. Y el enfrentamiento con el poder así concebido no aparece más que como transgresión.

Permite pensar la operación fundamental del poder como un acto de palabras: enunciación de la ley, discurso de la prohibición. La manifestación del poder reviste la forma pura del "no debes"xxiv 


\section{d- Objeto de estudio:}

Régimen de verdad en los discursos parlamentario y periodístico sobre los derechos indígenas en el contexto de la Convención Reformadora 1957-1994

\section{Construcción del objeto de estudio}

Este estudio trató de la palabra. La palabra y el Poder. El régimen de verdad que instauran. Dicho orden no es coercitivo. Actúa y recrea matrices discursivas.

El método del Orden es la relación inclusión/exclusión en el discurso.

Opera en todo tipo de discurso de poder.

Teun Van Dik animó la problematización del discurso parlamentario ${ }^{\mathrm{xxv}}$

Se trata de un caso que permitió construir una genealogía en torno de esa relación y dar cuenta de la palabra y el poder y su contexto en la discusión sobre Derechos Indígenas en el debate constitucional de 1994, en la Provincia del Chaco.

\section{Objetivo general}

Hacer explícitas las matrices del discurso de la Convención Constituyente de 1994 y de la prensa chaqueña, en el contexto de las interrelaciones entre actores, fracciones sociales y grupos dominantes, sobre el tema: pueblos originarios y sus derechos, para comprender las relaciones entre discurso, dominio y sociedad, que instauraron un régimen de verdad en el tema y contexto mencionados.

\section{Objetivos específicos}

1. Analizar la matriz discursiva del debate constitucional sobre el tema: pueblos originarios y sus derechos, en el contexto del debate y sanción de la Constitución 1957-1994 y sus interrelaciones actores, fracciones sociales, grupos dominantes.

2. Analizar la matriz discursiva de los medios de prensa gráfica, sobre el tema: pueblos originarios y sus derechos, en el contexto del debate y sanción de la Constitución 1957-1994, y sus interrelaciones actores, fracciones sociales, grupos dominantes. 


\section{e- Fundamentación}

"Estudiaba historia del Chaco y no entendía por qué se iniciaba un capitulo mencionando los indígenas del Chaco y el capitulo siguiente se titulaba "La epopeya colonizadora".

Tenía 16 años.

Tanto insistí en saber qué había pasado con los indígenas chaqueños, hasta que mi profesora en Historia, me concertó una entrevista con el historiador Carlos Primo López Piacentini. Muy renombrado en el Chaco. Ya fallecido.

Con busto frente al Museo de Medios de la Provincia, que fue el antiguo diario “El Territorio”, fundado por Ernesto Zamudio, radical yrigoyenista, habituado a la persecución politica. Uno de sus hijos, Carlos Zamudio, fue fusilado en la Masacre de Margarita Belén, en 1976.

Su diario fue expropiado por el primer gobernador de la Provincia Presidente Perón, Felipe Gallardo y entregado a la CGT.

Va esto a situar dónde está el busto de López Piacentini en la ciudad de Resistencia. Y su capital simbólico.

Relato la visita a López Piacentini: Concurrí a su casa.

Una vez sentados en su living, él en su sillón y yo en una silla cómoda-pero sillame dijo: “¿Qué querés saber, querida?”

- "Quiero saber qué pasó con los pueblos indígenas del Chaco desde la conquista hasta la colonización"

- " "Querida, no pasó nada. Fueron colonizados”.

Después, pasó a mostrarme sus libros y yo sentí que nacía una inquietud.

A veces, uno es testigo de los hechos. No tenía la edad necesaria para entender la seguridad de la afirmación, hasta hoy. Ni el sentido de la metáfora.

Ahora lo escribo como cronista, porque Carlos Primo López Piacentini, además fue Doctor Honoris Causa de la Universidad Nacional del Nordeste; al igual que Edgardo Rossi, abogado y militante de la Revolución Libertadora. También convencional de 1957.

Solo en la lectura del Diario de Sesiones de 1957 encontré una recopilación seria de los estudios históricos y antropológicos realizados a los indígenas del Gran Chaco Gualamba, su organización política y las primeras crónicas de los jesuitas sobre sus características. 
Las incursiones colonizadoras comenzaron alrededor de 1590. A menos de 100 años del desembarco de Colón.

Y yo creía que era una historia de 60 años" Gabriela Sosa More (2016)

El debate de la Convención Reformadora de 1994 permitió la construcción de un caso para estudiar el establecimiento de régimen de verdad.

Mis hallazgos indicaron que se consumó un capítulo más de la gesta colonizadora que marcó, primero al territorio nacional del Chaco- 1860-, continuó con su constitución como Provincia-en 1951-; se sostuvo en la Constitución de 1957 y se consolidó en la reforma Constitucional de 1994.

Estaba, otra vez, ante un capítulo más de la historia monumental (Barthes: 1985) del Chaco, como parte del Estado-Nación argentino.

Primero, la búsqueda se relacionó con la forma jurídica. Esta categoría atravesó la investigación y evidenció el modo de toma institucional/público de decisiones: Las Convenciones Constituyentes y las leyes que correspondiera dictar para su reglamentación; segundo: el tipo de temas de interés público: tierra (la propiedad y tipo de propiedad) y derechos indígenas.

Otra categoría de análisis fue el tipo de oratoria para las Asambleas que toman decisiones sobre los asuntos públicos: la oratoria deliberativa. Propia de la democracia delegativa. O representativa en tanto categoría a ser puesta en discusión.

Respecto de los periódicos que relataron estos acontecimientos (Alsina: 1989), se recurrieron a formas arquetípicas de mediación social (Serrano: 2008) a través de una organización mosaica de la información.

Al referirse a modelos, control social e ideología, Serrano expone: "La mediación introduce el sentido en acontecer social: concepto de sentido estructuralista y neopositivista. Cuando la mediación introduce un modelo de orden entre las cosas para ofrecer una visión estable del mundo se produce un cambio importante. La información del mediador cesa de tener por objeto la realizas original, "lo que ocurre" trata de explicar el orden. El suceso sirve para ilustrar una forma de consenso que ofrece un significado estable para interpretar el mundo xxvi 
Por tanto, lo social se entendió como una relación y no como una substancia y en la construcción histórica de lo social, el investigador debe poner el acento en el «acontecimiento» más que en las grandes «totalizaciones».

El concepto de lucha atravesó este estudio, vinculada al concepto de azar, como contingencia y al concepto de lucha, que a veces reemplaza por el de guerra y a veces por el de enfrentamiento.

El azar aparece como producto de las luchas en las que se enfrentan los hombres; el resultado de la batalla no está preformado, es algo contingente, aunque no casual; y la contingencia está constituida por la relación de fuerzas producida en un momento dado. No es una substancia. Tampoco un misterioso atributo cuyo origen habría que explorar (Murillo: 1997)

Mi carácter de testigo de los hechos en 1994, mi interés constante desde los 16 años sobre los asuntos indígenas, mi posterior trabajo con organizaciones indígenas para visibilizar sus luchas por la tierra, fueron parte de mi historia y de esta tesis. Decidí abstraerme con pasión en la interpretación de las matrices jurídica, discursivas y mediáticas para intentar algunas constataciones y conclusiones.

La propiedad de la tierra ya no es (en 2016) solo un problema de las comunidades indígenas, de hecho, obtuvieron un avance en comparación al estado anterior, escaso, indigno.

Las matrices que intervienen para este tipo de decisiones ameritan preguntar sobre la representación en la democracia, el metalenguaje de la retórica y la mediación social de los medios de comunicación el discurso conforma y construye en diferentes períodos y contextos, regímenes de verdad, que pueden presentarse, según sus propósitos pragmáticos como reproducción del orden, cambios o interacciones estratégicas entre actores, fracciones sociales, instituciones y medios de comunicación.

Para analizar el debate constitucional de 1994 fue necesario reconstruir la genealogía de la definición de los conquistadores y los sometidos; los colonizadores y colonizados.

La evidencia del texto constitucional remite a representaciones previas, preexistentes al momento del debate. 
Esos hallazgos se inscriben en la definición de Focault de genealogía del poder: un saber histórico, que supone dos ejes fundamentales en el análisis de la historia: los cuerpos y las luchas.

Se encontraron relaciones de inclusión /exclusión. La representación simbólica de los pueblos indígenas del Chaco se definió por parte de los representantes políticos en Civilización/ Barbarie.

Las fuentes documentales de este trabajo tienen un valor histórico: las tres versiones taquigráficas de las tres Constituciones del Chaco.

Y las interpretaciones de los autores intelectuales de la Reforma Constitucional Argentina de 1994.

El Estado Nacional fue rediseñado para la Reforma Administrativa- plan de privatizaciones-; para mantener el control político de los jueces (Consejo de la Magistratura); para demagogia e instauración del Estado de Derecho liberal.

De la Constitución de 1853, se mantuvo su corpus de principios, que posibilitaron sostener el Régimen de la Tierra Pública.

El asunto es que ya no existía el Estado- Nación.

La entrega del $30 \%$ de las tierras fiscales del Chaco a los pueblos indígenas, no era posible.

El derecho es la palabra escrita del poder.

Ya tenían otro destino. Es el juego de la palabra fingida, en términos de Barthes o la pragmática del mentir, en Van Dijk.

"El problema político esencial para el intelectual no es criticar los contenidos ideológicos que estarían ligados a la ciencia, o de hacer de tal suerte que su práctica científica esté acompañada de una ideología justa. Es saber si es posible constituir una nueva política de la verdad. El problema no es "cambiar la conciencia" de las gentes o lo que tienen en la cabeza, sino el régimen político, económico, institucional de la producción de la verdad.

No se trata de liberar a la verdad de todo sistema de poder- esto sería una quimera, ya que la verdad es ella misma poder-sino de separar el poder de la verdad de las formas de hegemonía (sociales, económicas, culturales) en el interior de las cuales funciona por el momento. 
La cuestión política, en suma, no es el error, la ilusión, la conciencia alienada o la ideología; es la verdad mismaxxvii”. (Focault: 1992. Microfisica del poder) 


\section{f- Propuesta teórico-metodológica}

Tipo de investigación: Análisis crítico de discurso. Se fundamenta en la propuesta de Teun Van Dijk, que define este tipo de análisis como un tipo específico de investigación y no solo un método.

Metodología: Cualitativa

Corpus de análisis:

- las versiones taquigráficas de 1951,1957 y 1994

- Tapas y crónicas de la prensa gráfica referidas a reuniones entre convencionales y actores, debate y sanción del artículo 34. Derechos indígenas.

\section{Consideraciones}

- Ante un sistema de medios de orden, en términos de mediación social (Serrano: $2008^{\text {xxviii }}$ ) la única posibilidad heurística fueron los registros de los debates parlamentarios.

- El caso estudiado prueba las categorías generales de palabra y orden, como cara y contracara de una misma unidad.

- La evidencia empírica fue puesta en discusión con el derecho positivo. Palabra y orden se mantuvieron como categorías.

- Para reconstruir la genealogía hubo que recurrir, al texto constitucional reformado de 1994 y diario de sesiones. A los textos constitucionales anteriores (1951 y 1957) y sus diarios de sesiones.

- Son los registros escritos de lo dicho.

- El análisis de la prensa escrita se analizó conforme a la relación inclusión/ exclusión, planteado por Teun Van Dijk, en sus análisis sobre la prensa escrita.

- El concepto de mediación social de Manuel Martín Serrano, también fue operativo para el análisis de la prensa escrita.

- Se buscaron relaciones que puede haber entre los acontecimientos pero procurando evitar cualquier totalización a priori y esta reconstrucción de genealogía rescata como la arqueología como método. Entendiendo ésta en su significado etimológico como la búsqueda de las leyendas, la historia antigua, los monumentos, los restos que tienen valor significativo. 


\section{g- Desarrollo Analítico}

1) Matriz comunicativa y la asignación o el orden del nombrar: Las provincias "Presidente Perón", "Chaco", y "Derechos indígenas", sus implicancias performativas

"Para los sofistas, hablar, discutir y procurar conseguir la victoria a cualquier precio, valiéndose de las astucias más groseras, es importante porque para ellos la práctica del discurso no está disociada del ejercicio del poder. Hablar es ejercer un poder, es arriesgar su poder, arriesgar, conseguirlo o perderlo todo. Alli hay algo muy interesante que el socratismo y el platonismo alejaron completamente: el hablar, el logos (...) Me parece igualmente importante que en los sofistas esa idea de que el logos o discurso es algo que tiene existencia material. Esto quiere decir que en los juegos sofísticos una vez que se dijo algo esto que se dijo permanece dicho.(...) Los discursos son efectivamente acontecimientos, tienen una materialidad" (Focault:1980)

En la investigación realizada, se pudo reconocer la matriz comunicativa en el orden de nombrar y asignar significados en el proceso de mediación social. El género oratoria deliberativa, es como todo género, un modo expresivo, modelo que organizan y presentan diversos componentes.

Un género es una estrategia comunicativa que implica ciertas reglas o leyes de producción y que da por resultado mensajes de diferente tipo.

El discurso parlamentario no solo tiene sus propias características y lógicas, sino que su uso fue creando normas y hábitos que forman parte de la experiencia cultural. Por ello, puede decirse que los géneros funcionan como verdaderos códigos comunicativos en tanto posibilitan el intercambio y la comprensión entre emisores y receptores.

De ahí que el uso de uno u otro género no es obra del azar.

En la interpretación de los géneros intervienen distintas competencias comunicativas: La competencia lingüística como el conocimiento del sistema de la lengua; la competencia temática como el conocimiento enciclopédico sobre el tema; la competencia textual como cualidad para producir textos acorde con la intención del autor; la competencia pragmática como el conocimiento acerca de 
los usos, estrategias y normas, para buscar algún tipo de cercanía con el lector/intérprete. Las competencias comunicativas aluden tanto al conocimiento de sí mismo como a la habilidad para realizarlo adecuadamente en un contexto específico.

En el discurso parlamentario, se reconoció también lo que Bourdieu denomina “competencia política, que no es universalmente repartida. La primera condición para responder de manera adecuada a una pregunta política es pues ser capaz de constituirla como política; la segunda es que, una vez que se ha constituido como política, hay que ser capaz de aplicarle categorías propiamente políticas".

En el debate chaqueño, se siguieron las reglas de interacción, entre convencionales, convencionales y grupos, convencionales y partidos políticos, convencionales y gobierno, convencionales y barra/público y periodistas con cada uno de esos actores.

\section{Discursos constitucional y de Junta}

Los textos jurídicos, producidos en el debate preacordado, son los documentos más cercanos al establecimiento del régimen de verdad.

El género “Convención”, "Junta”, es una modelización discursiva.

Es convocada para cambios de estatus jurídico. De orden jurídico. Para legislar hacia el futuro. Oratoria deliberativa, como califica Aristóteles. Para los asuntos públicos: la guerra, la paz, los recursos...

\section{La Constitución Reformada de 1994 es el resultado en forma jurídica del debate político.}

Para entender esa forma, se indagó las expresiones de los convencionales constituyentes nacionales y provinciales.

\section{Emergió también un modo de entender la democracia:}

"La tercera cuestión que preside el texto constitucional y que se encuentra en el artículo 75 es la siguiente: ¿la democracia debe ser entendida en términos meramente de soberanía popular? Consideramos que no, porque la democracia para nosotros y en el marco de todos estos postulados, debe ser entendida como democracia de las libertades de minorías; es decir, de una transferencia de la soberanía popular a los derechos del hombre. No la regla de las mayorías, sino protección de las minorías. Esto, es por tanto, lo que define al nuevo texto 
constitucional: democracia de libertades, juego de libertades, protecciones de minorías y no el sable de la regla de la mayoría popular con discriminación de las minorías $^{\text {xxix", escribió Elisa Carrió }}{ }^{\mathrm{xx}}$

\section{El concepto de justicia social se subsumió al de solidaridad social, "el nuevo nombre de la igualdad":}

"Entre los valores jurídicos incorporados y garantizados expresamente como nuevos derechos por la Constitución renovada, surgen la solidaridad social y la justicia social. La solidaridad es el nuevo nombre de la igualdad, es la seguridad de los débiles, es el predicado del desarrollo y del progreso individual (humano) e institucional (federal). La solidaridad no es un abstracto, es el socorro tangible y oportuno, es la asistencia fraterna personal e institucional del nuevo humanismo, es el camino verdadero de la paz"xxxi

"El progreso y la justicia, adjetivando el primero de económico y la segunda de social, constituyen el núcleo esencial para el desarrollo del futuro en el artículo 75, inciso 19. Guardando armonía con la Constitución histórica, repite la formula liberal del progreso sobre la base de la prosperidad y el adelanto, también con promoción, privilegio y estímulo ${ }^{\text {xxiii, }}$ argumentó Roberto Dromi.

Esto lleva a otra conclusión importante, los textos que llegan al debate constitucional, tuvieron antes autores y acuerdos políticos. Fue el caso de la Convención de 1994, que surgió en la Argentina tras el pacto de Olivos, firmado por el presidente Carlos Saúl Menem- y en representación del Justicialismo y el presidente (1983-1989) Raúl Alfonsín- en representación del Radicalismo.

El propósito pragmático era establecer un cambio que se llamó modernización del Estado, que implicó la privatización de las empresas públicas.

El estudio de los debates constitucionales argentinos realizado en la presente investigación encontró que antes de los debates, se acordaban los textos, previamente, en acuerdo político. Es por tanto una matriz de producción discursiva,

Juan Bautista Alberdi fue el escritor de la Constitución de 1853, con el documento previo: Bases y Principios para la organización nacional. 
La Constitución Nacional de 1994 fue escrita por Roberto Dromi, especialista en Derecho Administrativo y Elisa Carrió, especialista en Derecho Constitucional.

Que a su vez representaban el primero al Partido Justicialista y al Presidente Menem y la segunda a la Unión Cívica Radical y al Presidente Raúl Alfonsín.

Tras la sanción de la Constitución, el equipo de autores de los textos principales realizaron una compilación, que permitió entender el contexto político de los

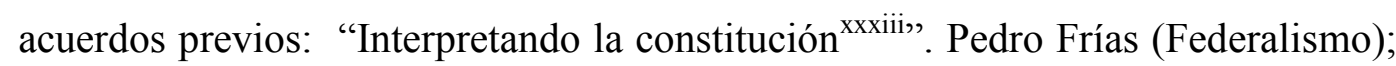
Roberto Gil Lavedra (Consejo de la Magistratura- Designación de jueces); Horacio Quiroga Lavié (Constitucionalismo).

Se evidenció que antes de la puesta en escena del género deliberativo, se realizaban los acuerdos previos. Estos acuerdos son los que organizaron el Estado argentino en 1853 y son pactos tendientes a mantener la "paz interior", que significa la administración de la guerra. Esta es una característica indispensable para reconocer la oratoria deliberativa.

De esos pactos, no participaron todos los legisladores, sino los líderes políticos y después proseguían los acuerdos desde un núcleo central a la periferia, es un espiral discursivo. Vale el ejemplo recordar los pactos entre provincias en $1853 \mathrm{y}$ el Pacto de Olivos de 1994:

“Detrás de los pactos entre las provincias estaba intangible el liderazgo de Rosas, Urquiza, Mitre, Ramírez, López, Paz y tantos otros jefes políticos de sus comunidades, regiones o provincias, tratándose de la organización nacional entre 1820 y 1860. Ahora en 1994, a propósito de la Reforma Constitucional, en el pacto entre el Partido Justicialista y la Unión Cívica Radical, cobra notoriedad el poder, la representatividad y la voluntad política de los presidentes de ambos partidos, Carlos Menem y Raúl Alfonsín, los que suman a su representatividad partidaria el consenso político que obtuvieron para acceder a la Presidencia de la República, con el voto popular mayoritario en 1983 y 1989 respectivamente. Esos datos de la realidad revelan que el liderazgo político también conduce, por voluntad consensuada, por voluntad pactada.

(...) los pactos previos a las constitucionales de 1853-60 y 1994 son la causa eficiente de estas Constituciones. Son pactos ordenadores, garantes, aseguradores, 
prudentes acuerdos para consolidar la continuidad jurídica, histórica y política de la Nación, bajo forma de república federal y municipal ${ }^{\text {xxiv }}$,

Se encontraron analogías en los modelos de producción discursiva tanto en las Convenciones Constituyentes como en los discursos de Juntas, en las culturas indígenas.

La ética y estética posmoderna ${ }^{\mathrm{xxx}}$, siguiendo a Esther Díaz (2005) justifican la omisión de las características de los pueblos indígenas de la Argentina, al presentar la cultura como monumento, artesanía, pluriculturalidad..

La existencia de las Juntas para decidir el uso de la tierra, los recursos, la guerra y la paz, permitió inferir que no es un metalenguaje únicamente occidental.

También hay registros de investigaciones antropológicas, citadas en la versión taquigráfica de la Convención provincial de 1957, de reuniones en el territorio del Gran Chaco Gualamba, donde la palabra Chaco se asocia además a una reunión para asuntos importantes, del que participaban los líderes de los pueblos indígenas.

Prácticas análogas reportan las meticulosas crónicas de Lucio V. Mansilla en "Una excursión a los indios ranqueles ${ }^{\mathrm{xxxvi}, "}$

\section{"Los indios ranqueles tiene tres modos y formas de conversar.}

La conversación familiar

La conversación en parlamento

La conversación en junta

La conversación en parlamento está sujeta a ciertas reglas; es metódica, los interlocutores no pueden ni deben interrumpirse; es en forma de preguntas y respuestas.

Tiene un tono, un compás determinado, su estribillo y actitudes académicas por así decirlo. (...)

El mérito del interlocutor en el parlamento, su habilidad, su talento, consiste en el mayor número de veces que da vuelta cada una de sus frases o razones; ya sea valiéndose de los mismos vocablos o de otros, sin alterar el sentido claro y preciso de aquellas.

De modo que los oradores de las pampas son tan fuertes en retórica como el maestro de Gramática de Moliere (...) 
Terminado el parlamento, vienen los juicios y las discusiones sobre las dotes de los que han sostenido el diálogo.

La conversación en parlamento, siempre tiene un carácter oficial. Se la usa en los casos como el mío (Mansilla) o cuando se reciben visitas de etiqueta (capitanejos indios)

La conversación en Junta: "Es un acto grave y muy solemne. Es una cosa parecida al parlamento de un pueblo libre, a nuestro congreso por ejemplo (...) Reúnase ésta, nómbrase un orador que expone y defiende, contra uno, contra dos o contra más, ciertas y determinadas proposiciones. El que quiere le ayuda.

El miembro informante suele ser el cacique. El discurso se lleva estudiado, el tono y las formas son similares a la conversación en parlamento, con la diferencia que en las juntas se admiten las interrupciones, los silbidos, los gritos, las burlas de todo género. Hay juntas muy ruidosas pero todas excepto algunas memorables que acaban a los capazos, tienen el mismo desenlace. Después de mucho hablar triunfa la mayoría aunque no tenga razón. Y aquí es el caso de hacer notar que el resultado de una junta siempre se sabe de antemano porque el cacique principal tiene buen cuidado de categorizar con tiempo a los indios y capitanejos más influyentes en la tribu.

Todo lo cual prueba que la máquina constitucional llamada por la Libertad Poder Legislativo, no es una invención moderna extraordinaria; que en algo nos parecemos a los indios, o, como diría Fray Gerundio: en todas partes se cuecen habas"

Lucio V. Mansilla fue gobernador del Territorio Nacional del Chaco. $\mathrm{Su}$ mandato abarca desde el 28 de octubre de 1878 hasta el 5 de noviembre de 1880 .

Destaco que esta forma de Junta, llamada también Asamblea, sigue vigente en las comunidades indígenas (2016) y fueron formas adoptadas para llevar la posición de los pueblos wichí, qom y mocoit ante la Convención Reformadora Constituyente de 1994. 


\section{Relación de discurso constituyente con oratoria deliberativa}

El discurso constituyente se distinguió entonces como una tipología específica, por el tipo de asuntos que trata y su modo de representación.

La vinculación con la propiedad, se argumentó siguiendo a Barthes (2009):

"La retórica (como metalenguaje) nació de los litigios sobre la propiedad. Alrededor del año 485 dos tiranos de Sicilia, Gelón y Hierón, llevaron a cabo deportaciones, y ordenaron emigraciones y expropiaciones para poblar Siracusa y distribuir porciones de tierra entre los mercenarios; cuando fueron derrocados por una sublevación democrática y se quiso volver a la situación ante qua, hubo innumerables procesos porque los derechos de propiedad habían caído en la confusión. Estos procesos eran de un tipo nuevo: movilizaban jurados populares con gran número de miembros, ante los cuales, para convencer, había que ser «elocuente». Esta elocuencia participaba a la vez de la democracia y de la demagogia, de lo judicial y de lo político (lo que luego se llamó de deliberativo) y se constituyó rápidamente en objeto de enseñanza. Los primeros profesores de esta nueva disciplina fueron Empédocles de Agrigento, Córax, su alumno, de Siracusa (el primero que se hizo pagar sus lecciones) y Tisias. Esta enseñanza pasó no menos rápidamente al Atica (después de las Guerras Médicas), merced a los pleitos de comerciantes, que litigaban conjuntamente en Siracusa y en Atenas: la retórica es ya, en parte, ateniense desde mediados del siglo V. A.1.2. Una gran sintagmática ¿Qué es esta protorretórica, esta retórica de Córax? Una retórica del sintagma, del discurso, y no del rasgo, de la figura.

Córax posee ya las cinco partes de la oratio que formarán durante siglos el «plan» del discurso oratorio: 1) El exordio; 2) la narración o acción (relato de los hechos); 3) la argumentación o prueba; 4) la digresión; 5) el epílogo. Es fácil comprobar que al pasar del discurso judicial a la disertación escolar este plan mantuvo su organización principal: una introducción; un cuerpo demostrativo; una conclusión. Esta primera retórica es, en suma, una gran sintagmática.

(...) Resulta curioso comprobar que el arte de la palabra está ligada originariamente a una reivindicación de la propiedad, como si el lenguaje, en cuanto objeto de una transformación, condición de una práctica, se hubiera determinado no a partir de una sutil mediación ideológica (como le ha sucedido a 
tantas formas de arte), sino a partir de la socialidad en su máximo grado de desnudez, afirmada en su brutalidad fundamental, la de la posesión de la tierra: se comenzó -entre nosotros- a reflexionar sobre el lenguaje para defender las posesiones. En el nivel del conflicto social es donde nace un primer esbozo teórico de la palabra fingida (diferente de la palabra ficticia, la de los poetas: la poesía era entonces la única literatura; la prosa sólo posteriormente accede a este estatuto) $)^{\text {xxxvii }}$.

\section{Proclamas, Manifiestos y Constituciones}

Las Convenciones tienen una diferencia respecto de otros documentos como las proclamas y manifiestos, aunque se vinculan en el sentido que surgen a partir de la proclamación de ideas políticas.

La diferencia es el acuerdo entre representantes elegidos por el pueblo, por algún tipo de Asamblea.

El desarrollo de las Asambleas Constituyentes tiene un tiempo de debate y consenso. Por ello, la fuerte crítica a la Constitución de 1949 y de 1951 en el Chaco, que por la rapidez con que fue aprobada y su carácter predominantemente político, más que jurídico, fue uno de los argumentos para su derogación. En 1951, se cumplió con el tratamiento de todo el articulado y su sanción en tres días. Se evidenció que existe un cronotopo: un tiempo y un lugar para la forma constitucional y las condiciones que deben reunir sus representantes, como así también la exhibición de argumentos jurídicos para su tratamiento, por encima de la forma política.

Son dos tipos de discurso: el primero, de oratoria deliberativa y el segundo de oratoria epidíctica, orientada a las pasiones. Según la concepción del pensamiento conservador dominante.

La primera Constitución Provincial fue asociada a una proclama de un tirano, en el mismo sentido que se dio a Rosas.

En juego se ponían las visiones contrapuestas de país, la fuerte lucha de intereses y la rapidez para imponer reformas más propias de una revolución que de una República.

El ingreso de la clase trabajadora había cambiado también la concepción de pueblo, y por ello los representantes elegidos para esa Convención representaban, según sus detractores a solo una parte del pueblo. 
La representación de esta concepción de trabajadores organizados, cambiaba la relación del voto, vía doble voto sindical en la Legislatura.

El retorno al modelo constitucional de 1853, con la abolición de la Constitución de 1949 (en la Nación) y la de 1951 (en el Chaco) retomó los principios de la unidad nacional, concebida por los convencionales de Santa Fe en 1853.

También la organización de una Convención que cumpliese con los requisitos de convencionales jurisconsultos por sobre los representantes obreros, considerados como una facción sostenida por la tiranía del gobierno peronista depuesto.

Respecto de los manifiestos, -del latín manifestus, es un documento o escrito a través del cual se hace pública una declaración de propósitos o doctrinas. Los manifiestos suelen aparecer en el ámbito de la política o del arte- se halló la asociación por el cronotopo.

Como ejemplos, se recuerda al Manifiesto Comunista, redactado por Karl Marx y Friedrich Engels, uno de los tratados políticos más difundidos de la historia. Fue publicado por primera vez en 1848 .

También existe otro manifiesto de carácter político que goza de un gran valor histórico y social. Se trata la Declaración de Independencia de los Estados Unidos, cuya asociación con el documento de Alberdi, se analizó en el capítulo referido a forma jurídica.

\section{Los pactos pre-existentes}

Se reconoció en este trabajo, que la relación comunicativa predominante se orientó al establecimiento de pactos. La comunicabilidad atraviesa las actividades humanas y las expresa en símbolos, rituales, y dentro de esos rituales, uno nos ocupa en el caso de estudio: el Pacto.

El Pacto solo puede ser suscripto entre iguales. En posición simétrica.

Su propósito pragmático es asegurar la paz entre iguales.

En términos de fuerza, y generalmente después de varias luchas.

El pacto es asimilable a un contrato, porque es suscripto entre pares y de hecho se expresa la voluntad de las partes en iguales términos y condiciones sobre aquel producto comunicativo que van a respetar hacia el futuro para evitar la guerra, es 
decir, como expresa el preámbulo de la Constitución Nacional "asegurar la paz interior".

Prosiguiendo con el análisis de matriz jurídica como instauración de un régimen de verdad, hay un movimiento discursivo necesario de reconocer.

Y se trata sobre la naturaleza jurídica de las provincias, donde la Constitución Nacional, otorga estatus jurídico a las provincias pre-existentes a la organización nacional, mientras las otras fueron creadas por Ley del congreso y por tanto, también queda bajo su competencia su anexión a otras o su desaparición.

"Por principio general las Provincias Unidas preexisten al Estado Argentino y sus facultades jurisdiccionales abarcan los territorios que España asignó a las ciudades, que luego se convertirían en las provincias argentinas- fundadoras- por ser éstas las sucesoras de la Corona Española en el ejercicio del dominio eminente desde 1810. Aunque la sucesión no será tranquila ni pacífica, deslindes imprecisos y controvertidos se sumarán a los problemas internos, guerras civiles inclusive que al momento del dictado de la Constitución de 1853, muestra títulos imperfectos con relación a sus territorios, es por ello que el Congreso de la Nación será el encargado de fijar los límites, pero a la vez la Constitución garantiza la existencia territorial de la entidad provincial $^{\text {xxxviii }}$

“Linares Quintana asevera que "La garantía del derecho a la existencia integral, indestructibilidad e integridad territorial de las Provincias, inherente a su calidad de Estados, a la que su condiciones de entidades políticas soberanas- las Provincias originarias-existentes a la Constitución Nacional (Preámbulo, arts $3^{\circ}$, $6^{\mathrm{o}}, 13^{\mathrm{o}}$ y concordantes)... Del mismo modo que dentro del esquema del estado Federal el Estado Nacional tiene derecho a su existencia integral, para lo cual la Constitución le provee de los medios jurídicos idóneos, los Estados regionales o Provincias, en cuanto Estados autónomos, han retenido su elemental derecho a la vida en su plenitud, con mayor razón todavía, en el caso de las Provincias argentina en su calidad de Provincias originariamente sobernas e independientes, preexistentes a la creación constitucional del Estado federativo". Se colige que el derecho constitucional argentino reconoce a las provincias originarias, el derecho a existir integralmente, en todo o en sus partes constituyentes, tal poder que fuera retenido al conformar el Estado Federal está por encima de toda delegación que hubieran hechos los estados provinciales a la Nación, que es el derecho primigenio a la existencia de la entidad "Provincia", afirma el autor citado que es 
similar al derecho a la vida de las personas individuales. A partir de la existencia necesaria y obligatoria prevista en la Constitución Nacional de las Provincias, siempre refiriéndome a las constituyentes y su indestructibilidad, se habla de la igualdad de las mismas (Provincias) también referidas a las fundadoras ${ }^{\text {xxix },}$

\section{El concepto de Provincia}

¿Tienen la misma relación de simetría las provincias pre-existentes a las creadas por Ley del Congreso?

¿Son parte, en el mismo estatus, rol que las provincias fundadoras?

"Históricamente las provincias constituyentes han preexistido a la Nación. "La afirmación es axiomática. Si en 1853 ellas concurrieron a Santa Fe a despojarse de aquellos poderes que constituirían el acervo gubernativo de la Nación, es evidente que tenían una personalidad preexistente, que supieron fortalecer en las luchas regionales hasta conseguir su reconocimiento en la Constitución. Sabido es que las provincias argentinas fueron dentro del derecho patrio (1810-1853), Estados con plenos poderes dentro de una Confederación invertebrada e imperfecta, lo demuestra Corrientes por sus largos y solitarios desencuentros con el poder central de Buenos Aires, sus guerras y el ejercicio de su soberanía con expedición de pasaportes, constitución de tribunales de presas, relaciones internacional, papel moneda, guerra y paz, etc. Esta plena soberanía ejercida realmente que concluye con la Constitución de 1953; les permite a los estados constituyentes conservar los derechos no delegados y reservar a los Estados que se incorporen, previendo el caso de Buenos Aires, los derechos que se acuerden como lo hizo esta última por el ejemplo con el Banco de la Provincia de Buenos Aires por el Pacto de San José de Flores y sendas convenciones (provincial y nacional) ${ }^{\mathrm{xl}}$

\section{Las provincias creadas por ley}

Las actuales provincias (2016) del Chaco y La Pampa, fueron creadas por Ley en el gobierno del Presidente Juan Domingo Perón. La primera se denominó Provincia Presidente Perón y la segunda, Provincia Eva Perón. Se provincializaron así los territorios otrora Nacionales. 
Estos extensos espacios, durante el siglo XIX "generaban preocupación de los gobernantes avocados a la construcción del Estado Nacional. La tierra que constituía el desierto era apetecida por los imperios extranjeros o los incipientes Estados vecinos. El desafío consistía en ocupar efectivamente el territorio, único y legítimo título que se podía oponer al posible ocupante. Gobernar es poblar era la consigna como lo afirmaba Alberdi aunque: "Sarmiento ya lo había expresado en la introducción de 1845 al Facundo y un itinerario consecuente unirá aquel texto con los sucesivos sobre el centenar de inmigrantes de Chivilcoy (visto como modelo de colonización agrícola), que debía ser el núcleo de una obra de gobierno. La inmigración tenía que poblar el desierto mediante la colonización agrícola, construir la sociabilidad argentina, que la extensión y el despoblamiento hacían inexistente. En ella los inmigrantes eran los actores de un cambio, pero no principalmente en su condición de portadores de una cultura especial, en sentido amplio, sino en tanto ellos serían los brazos de una agricultura cuyo poder de transformación sería extraordinario ya que eliminaría al desierto y sus productos, sociales y políticos. Para cumplir ese papel Sarmiento no necesitaba de un tipo de inmigrantes particulares (si ellos no eran modernos, sus hijos lo serían a través de ese instrumento transformador que era para el autor del Facundo, la escuela pública). "Gobernar es poblar" es, en realidad, un motivo más sarmientino que alberdiano...". El Estado debía tener presencia, con seguridad, justicia, educación, defensa, un aparato administrativo que responda a las autoridades, con el fin de evitar caer en el juego de Alicia en el país de las maravillas, en que el poder coactivo de la reina no alcanzaba a capturarla, necesariamente había que establecer habitantes que planten la bandera nacional, sus símbolos patrios, el himno, la escarapela, el lenguaje y la aplicación efectiva de la constitución nacional por tribunal que respondan a la soberanía estatal. Formar un Estado (el censo, el mapa y el museo) y delimitar el territorio constituían los pasos necesarios, para ello el Congreso tiene la facultad de fijar los límites provinciales y disponer del uso de la enajenación de las tierras de propiedad nacional $(\ldots)$ Arreglar definitivamente los límites del territorio de la Nación, fijar los de las provincias, crear otras nuevas, y determinar por una legislación especial la organización, administración y gobierno que deben tener los territorios nacionales, que queden fuera de los límites que se asignen a las provincias ${ }^{\mathrm{xli}}$, 
Las provincias precursoras fueron las que debían remitir los datos e informes para que el Congreso Nacional fije los límites provinciales. Un asunto nada menor, que también originó varias disputas entre provincias por la extensión de sus límites.

Por tanto, "el modelo seguido fue el gobierno de las provincias constituyentes, con bases fundamentales de tres poderes. Queda entendido que no tenían el mismo estatus porque carecían de personalidad autonómica por lo tanto quedaban reducidos al papel subalterno de simples divisiones administrativas de la Nación. Este era el paso previo para poder convertirse en provincia, debían alcanzar 60.000 habitantes según el censo general, tampoco podía entenderse que se trataba de un proceso mecánico que implicara que alcanzados el número de habitantes, se convertirían en provincias, era facultad del Congreso de la Nación y lo ejercitará cuando lo creyera conveniente. Estos territorios tenían un poder ejecutivo elegido por el Poder Ejecutivo Nacional con acuerdo del Senado, secundado por otro funcionario que refrendaba sus actos, una legislatura local, gobiernos municipales y justicia propia ${ }^{\text {xlii, }}$

Las campañas militares hacia el monte, en el Norte argentino y al Desierto, hacia el sur, permitieron la constitución de los Territorios Nacionales. Es decir de la ocupación efectiva, que permitiese la constitución de la Nación.

El ocupante original, el indígena fue masacrado en los casos en que opuso resistencia, o incluido como mano de obra barata.

“... No se buscaba su exterminio sino la vigencia de las antiguas instituciones castellanas e indianas más cercanas a la esclavitud que a la dignidad del ciudadano, realidad que se mantiene en las provincias que aún conservan minorías originarias de la tierra. El abuso que soportaron los aborígenes llegó a extremos espeluznantes cercanos a un verdadero genocidio muy poco conocidos en la historia argentina que cuidadosamente fueron omitidos por parte de los historiadores, con raras excepciones ${ }^{\text {xliii, }}$.

En capítulos siguientes, se analizó el debate en 1957 sobre la abolición, en el Chaco, de las instituciones castellanas e indianas: la encomienda y la misión. En términos declarativos, al menos. 


\section{El indígena en los Territorios Nacionales}

La encomienda continuó hasta entrado el siglo XX por necesidad de supervivencia, de parte de las poblaciones indígenas y como incorporación de mano de obra barata.

"El territorio comprendido entre el Bermejo y el Pilcomayo fue ocupado militarmente en 1911, mientras las colonias agrícolas, las fábricas de tanino, los algodonales y los ganaderos reducían en la región central los antiguas territorios de caza y de recolección. Los indígenas acudían frecuentemente a los destacamentos militares o a las misiones, declarando su propósito de reducirse y pidiendo alimentos y ropas, al cabo de un tiempo, retornaban al monte especialmente en la estación de la algarroba. Generalmente se los hacía responsables del cuatrerismo y de los hurtos (aunque los criollos solían estar también implicados) y eran castigados muy duramente, lo que explica el terror que sentían por los uniformados ${ }^{\text {xliv" }}$.

De esa época se remontan las masacres de Napalpí, con el gobernador Centeno a cargo del Territorio Nacional del Chaco, donde se hizo creer a la población criolla que se venía un malón, cuando se trabaja de un reclamo por el precio del algodón que se pagaba a los cosecheros indígenas. También, la de Rincón Bomba, en el territorio Nacional de Formosa, por alimentos en mal estado.

\section{La posesión de la tierra}

"El fruto de las campañas al desierto fue una gran oferta de tierra que generó una extraordinaria expansión agraria. Los territorios nacionales fueron ocupados por los grandes flujos de inmigrantes que gracias a la escuela pública tal como había previsto Sarmiento, sus hijos fueron asimilándose al Estado Nacional, no sin algunas preocupaciones por casos especiales en que el idioma, costumbres, religión y otros hábitos conspiraban contra la integración al nuevo Estado y su asimilación plena como ciudadanos ${ }^{\mathrm{xlv}}$,

La ocupación efectiva de la tierra, conformaría parte del Régimen de Tierra Pública y en las Constituciones del Chaco, seguiría el mismo propósito pragmático. 
Hasta el lema de "la tierra es para quien la trabaja", que argumenta el gobernador Gallardo (1953) en una nota, para renunciar a una parcela de tierra que se le había adjudicado y cuya disposición llegó cuando ya era gobernador, era la representación simbólica del Chaco.

Era el argumento por el cual cualquier colonizador criollo o extranjero que tomase posesión de la tierra con el fin de trabajarla, entendiéndose como agricultor, ganadero o cualquier actividad económica, lo ponía en ventaja legítima y legalvía Régimen de Tierras Públicas- de expulsar a los ocupantes indígenas. O sumarlos a la actividad económica, manteniendo la encomienda como relación contractual asimétrica.

\section{Colonización y exterminio}

"En 1884 las tropas del Ejército y la Marina, encabezados por el general Benjamín Victorica, realizaron una campaña militar que fue la culminación de una serie de entradas al Chaco que llevaba por lo menos trescientos años. Este ingreso definitivo partió desde Salta, Santa Fe y Corrientes. Aunque los indígenas no fueron sometidos totalmente, la campaña significó la derrota militar de los mismos (...) Algunos indígenas se alistaron como peones en los obrajes ribereños. José Garmedia, a cargo del Diario de la Campaña de Victorica, señala como uno de los resultados de la expedición "que obligará a 15 o 20.000 brazos viriles que estaban inútiles (...) a entregarse a los beneficios de la civilización”. Mientras tanto continuaba la entrega de tierras a la industria taninera( Barreto, E: 2009) Fortines afianzados, Paraguay vencido. La "verdad" se hacía régimen, una sola Argentina y se iniciaban los contingentes inmigratorios.

Este "pacto civilizatorio" no incluía como sujetos de derechos a los indígenas, por el contrario marcaba su exterminio y clausura, abolida la soberanía territorial y la organización política, para dar lugar a una sociedad que sentaba las bases del liberalismo, pero desde los términos de una República que nacía también por “acuerdos pre-existentes" con las potencias internacionales.

“A partir de la ley Avellaneda, en 1876, ingresan contingentes inmigratorios y se funda la que después sería ciudad capital Resistencia, formándose colonias agrícolas. El propósito del plan que primero instaló a los colonos europeos y después a los criollos- era "educar al paisano con el trabajo asiduo del inmigrante 
(...), pronto éstos, las familias criollas rivalizarían con ellos en industria y

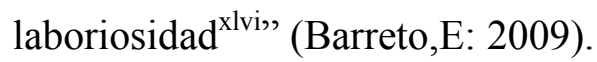

Los "indios chaqueños" conocieron la explotación en los ingenios azucareros, en la cosecha del algodón y en la industria forestal-taninera. Controlados por las policías privadas de estas empresas de capitales ingleses, más los "gringos" los "otros" de la corriente inmigratoria.

Sin embargo, se documentan huelgas, una de ellas "La masacre de Napalpí" que se originó por el reclamo por el precio de venta del algodón, mientras se rumoreaba en los "blancos" el peligro del malón y los diarios de la época mencionaban la amenaza india. Esta fue una lucha que duró hasta su casi completa doblegación, entendiendo que debían renunciar a su otredad, su identidad, para construir una identidad chaqueña- marcada por los "gringos"- y por tanto, pasaban a ser sujetos controlados en su visibilidad pública.

Cabe decir que ésta era una de las últimas expresiones indígenas como pueblo, ocurrida en 1920.

Para dar una idea del exterminio, la población indígena en el Chaco en 1912, era 25.000 "salvajes"; en 1914, 2.214 y en 1920, 5.000 "salvajes" (Barreto: 2009)

En los inicios del siglo XX hasta la provincialización, fueron numerosos los episodios de enfrentamiento por la tenencia y propiedad de la tierra, también por las condiciones de explotación a la que estaban sometidos criollos e indígenas, en los obrajes y en la cosecha algodonera y el poder de fijación de precios que tenía Bunge y Born, en la compra de algodón.

“También el fuerte control político de las corporaciones inglesas, francesas y estadounidenses en el Territorio. Bunge y Born contrató los servicios como abogado del entonces Gobernador del Territorio.

Hay registro de dos huelgas algodoneras, en 1934 y 1936, siendo caracterizadas ambas con propósitos diferentes por los estudios realizados, pero ello muestra el tipo de relación de dominio que se ejercía sobre los habitantes y que formarían parte de los argumentos expuestos por las juntas de promoción, las cooperativas y los sindicatos, para justificar la constitución de una provincia ${ }^{x l v i i, ”}$.

Ese reclamo a la Nación, comenzó a ser orientado a partir de 1943, por las organizaciones sindicales y con mayor vigor después de 1945, al alcanzar su reconocimiento de existencia jurídica y política con la ley de Asociaciones Profesionales, entre otras. 


\section{La mirada/construcción del "otro": Quiénes eran los pueblos indígenas del}

Chaco para los colonizadores

La Convención Constituyente de 1957 presentó una indagación de crónicas que permitieron comprender una construcción de inclusión/exclusión de ciudadanos/no ciudadanos/indígenas.

El Diario de Sesiones de 1957 realizó una recopilación de los estudios históricos y antropológicos realizados a los indígenas del Gran Chaco Gualamba, su organización política y las primeras crónicas de los jesuitas sobre sus características.

Las incursiones colonizadoras comenzaron alrededor de 1590. A menos de 100 años del desembarco de Colón.

\section{- Conquista de los chacogualambas}

"En 24 de diciembre de 1596, por una información de méritos y servicios semejantes, Francisco de Argañaraz, fundador de la ciudad de Jujuy, solicita al Rey se le conceda permiso para realizar, con el título de Adelantado, la "conquista de los chacogualambas tierra incógnita a la vuelta de la cordillera de Jujuy “. Al prestar declaración de dicho testimonio, el vecino de Salta, Sancho Pérez Morillo certificó la existencia de dicha provincia, en mérito a que había marchado personalmente "al dicho descubrimiento... con el capitán Pedro Lasarte y a llegado hasta tres jornadas de la población de los dichos indios e que por la noticia de la mucha gente que ay en dicha provincia se volvió".

\section{- Región geográfica/Nación etnográfica}

"Téngase en cuenta ahora que el nombre de Chaco Gualamba era aplicado por Ramírez a una región geográfica y por Argañaraz a una nación etnográfica, fenómeno común en la época, que originó como veremos más adelante el mito del Gran Chaco Gualamba. Según Antonio Serrano la terminación "gualamba” es una desinencia propia del idioma o dialecto de los lules. El mismo autor ha aseverado en otras ocasiones: "Ocupaban estos lules la parte llana de la provincia de Salta al 
sur del Bermejo, la región del Salado en el Noroeste de Santiago del Estero y parte de la provincia de Tucumán". Y: "Es evidente que el territorio designado en el Perú en la época inicial de la conquista con el nombre de Chaco Gualamba es el ocupado por los indígenas(tonocotés, lules y vilelas), de los cuales acabamos de hablar". Como se demuestra la cienca etnográfica actual ubica de una manera evidente los contornos del primitivo Chaco Gualamba: Tonocotés, eran por otra parte los 20.000 aborígenes que descubrió Alonso de Vera y Aragón en Matará y también los pobladores de Guácara, encomendados a Antón Martín, vecino de Esteco".

\section{- Cambios en los pueblos indígenas con la conquista}

"Las jornadas en busca de los indios que se fugaban de las encomiendas dieron ocasión a tropelías y venganzas. Al mismo tiempo entre los indígenas se operó un cambio evidente: la asimilación del caballo importado por los españoles modificó fundamentalmente la cultura de los naturales. "Como ya hemos indicado- dice el conocido antropólogo norteamericano Paul Rodin- en los bordes del Chaco (al oeste, al norte y al este), la vida era relativamente fácil. Todas las tribus que allí vivían eran sedentarias. Algunas de ellas habían sufrido la profunda influencia de las grandes civilizaciones andinas y creando centros secundarios propios. El único lugar por donde podían escaparse estas tribus atrapadas contra su voluntad en el centro de esa región desolada estaba ocupado por pueblos que disponían de amplios medios para protegerse contra los ataques en las condiciones corrientes. Y así los mbayá-kadiueos, los abipones y los tobas eran mantenidos en un estrecho cerco para romper el cual de nada servían todos sus esfuerzos. La situación cambió con la llegada de los españoles. Durante los conflictos con éstos las tribus del Chaco se retiraron cada vez más a su difícil región para protegerse todo el tiempo que pudieran contra los europeos irrespetuosos e indisciplinados... Esas tribus no permanecieron allí largo tiempo. Pero cuando salieron finalmente lo hicieron a caballo y comenzó su nueva carrera".

Las tribus guaycurúes (chaquenses típicos) encararon el renacimiento de la estirpe nativa: los lules, tonocotés, vilelas, desaparecieron ensombrecidos por los mocovíes, abipones y tobas y en pocos años los españoles abandonaron los llanos extendidos entre los ríos Paraná y Salado y perdieron la noción de sus lindes 
geográficos. Tan así que en 20 de noviembre de 1644 Martín de Ledesma y Valderrama escribía al Rey refiriéndose a "la nueva provincia del Chaco quees a las vertientes dela cordillera del rreyno del peru hacia los llanos y nacimientos del sol" con un número casi infinito delagentilidad que la abitan hatalabocay rremate del rrio del marañon".

\section{- Guerra por el territorio}

"Las ciudades de la corriente colonizadora del Norte: Jujuy, Salta, Esteco, se veían obligadas a enfrentar terribles malones. Concepción del Bermejo fue arrasada en 1632; Corrientes, santa Fe y Córdoba vieron llegar mocoviés y abipones a los umbrales de sus poblaciones y en esa carta al Rey del Gobernador de Tucumán, Angel de Peredo, fechado 1673, se lee: "ser este genttio el mas barbaro y Ynculto q se a reconosido en todas estas provincias...” Por otra parte en 1691 decía el arzobispo de Charcas al acusar recibo de una Real Cédula: "También tengo por inútil al medio embiarle misiones por ahora:porque los dos Csacos están insolentes y los pasarán a cuchillo (dixit)"

Habiendo puesto fin la conquista del Perú a la dramática carrera de los aventureros del Río de la Plata, a través del continente, en pos de la Sierra del Plata, que no tuvieron otros motivos los viajes referidos por Alonso de Vera y Aragón y desaparecidos sus actores la leyenda cubrió de nuevo los términos de aquellos llanos, bosques y bañados inextinguibles que separaban a Asunción de Tucumán y del Perú, asociado a la impenetrabilidad del Chaco Gualamba, en razón de la creciente aptitud guerrera de los indígenas, a la vasta comarca por la que ellos se expandían. Tal proceso coincidió con el establecimiento de los jesuitas y la iniciación de los trabajos historiográficos que Rómulo Carbía designa “crónica jesuítica”. "Llenan ellos el siglo XVII, más de la mitad del XVIII y se prolongan, como producción personal de los expulsos en el resto de la centuria.

El padre Pedro Lozano, uno de los más famosos y difundidos, publica en 1733 una "Descripción Chorográfica del Gran Chaco Gualamba", donde recoge la suma de conocimientos, hechos e imaginerías que ha forjado la tradición colonial, en torno de esa provincia indomeñable y que constituye la obra que mayor influencia ha tenido en las ciencias histórico-geográficas, con respecto a la consideración de la comarca. Al ubicarlo, en los párrafos iniciales, expresa que el Chaco comprende "varias provincias pobladas de naciones infieles, que se continúan y 
comunican unas con otras, por centenares de leguas en la banda del poniente y del Río de la Plata, entre las provincias del Paraguay, Río de la Plata, Tucumán, Chicha, Charcas y Santa Cruz de la Sierra. La significación etimológica del nombre es tomado predominantemente en sentido etnográfico y así dice que "Chaco indica la multitud de Naciones que pueblan esa región”, y refiriendo seguidamente "cuando salen a cazar los indios y juntas de varias partes las vicuñas y guanacos, aquella muchedumbre junta se llama Chaco”.

\section{La vida política de las naciones indígenas}

Se distinguieron los siguientes conceptos clave, extraídos del Diario de Sesiones de 1957:

\section{- Nación y Territorio}

Se reconocían límites territoriales: "una nación etnográfica, fenómeno común en la época, que originó como veremos más adelante el mito del Gran Chaco Gualamba. Según Antonio Serrano la terminación "gualamba" es una desinencia propia del idioma o dialecto de los lules. El mismo autor ha aseverado en otras ocasiones: "Ocupaban estos lules la parte llana de la provincia de Salta al sur del Bermejo, la región del Salado en el Noroeste de Santiago del Estero y parte de la provincia de Tucumán”. Y: "Es evidente que el territorio designado en el Perú en la época inicial de la conquista con el nombre de Chaco Gualamba es el ocupado por los indígenas(tonocotés, lules y vilelas), de los cuales acabamos de hablar". Como se demuestra la cienca etnográfica actual ubica de una manera evidente los contornos del primitivo Chaco Gualamba"

\section{- Organización política}

Había una organización política, previa a la colonización, formada en la defensa del ataque de Adelantados en la Conquista: entre los indígenas se operó un cambio evidente: la asimilación del caballo importado por los españoles modificó fundamentalmente la cultura de los naturales. "Como ya hemos indicado- dice el conocido antropólogo norteamericano Paul Rodin- en los bordes del Chaco (al 
oeste, al norte y al este), la vida era relativamente fácil. Todas las tribus que allí vivían eran sedentarias. Algunas de ellas habían sufrido la profunda influencia de las grandes civilizaciones andinas y creando centros secundarios propios. El único lugar por donde podían escaparse estas tribus atrapadas contra su voluntad en el centro de esa región desolada estaba ocupado por pueblos que disponían de amplios medios para protegerse contra los ataques en las condiciones corrientes. Y así los mbayá-kadiueos, los abipones y los tobas eran mantenidos en un estrecho cerco para romper el cual de nada servían todos sus esfuerzos. La situación cambió con la llegada de los españoles. Durante los conflictos con éstos las tribus del Chaco se retiraron cada vez más a su difícil región para protegerse todo el tiempo que pudieran contra los europeos irrespetuosos e indisciplinados... Esas tribus no permanecieron allí largo tiempo. Pero cuando salieron finalmente lo hicieron a caballo y comenzó su nueva carrera".

\section{- Tipo de organización política}

Esta organización era jerárquica, con representantes y hubo guerra por el control del territorio:"Las tribus guaycurúes (chaquenses típicos) encararon el renacimiento de la estirpe nativa: los lules, tonocotés, vilelas, desaparecieron ensombrecidos por los mocovíes, abipones y tobas y en pocos años los españoles abandonaron los llanos extendidos entre los ríos Paraná y Salado y perdieron la noción de sus lindes geográficos”.

\section{- Matriz de Comunicación en los pueblos indígenas}

Existían acuerdos y comunicación entre los pueblos: "el Chaco comprende "varias provincias pobladas de naciones infieles, que se continúan y comunican unas con otras, por centenares de leguas en la banda del poniente y del Río de la Plata, entre las provincias del Paraguay, Río de la Plata, Tucumán, Chicha, Charcas y Santa Cruz de la Sierra"

Se podría inferir la constitución de Juntas para la toma de decisiones, en un espacio asignado, que finalizaba con una práctica ritual: "“"Chaco indica la multitud de Naciones que pueblan esa región", y refiriendo seguidamente "cuando 
salen a cazar los indios y juntas de varias partes las vicuñas y guanacos, aquella muchedumbre junta se llama Chaco"

\section{Matriz de comunicación de pueblos indígenas}

Temas de interés colectivo para el futuro de los pueblos: guerra, paz, propiedad, recursos, tributos

Lugar: asignación de un espacio simbólico y físico para la deliberación.

Roles: representante elegido por el pueblo, mediante games de poder, estrategias y tácticas; pueblo que aprobaba o desaprobada fuera del recinto de deliberaciones- sea cual fuera esta- sin poder de intervenir en el debate. Informantes de las deliberaciones al resto de los miembros de los pueblos (en las prácticas previas a la colonización);

Inicio y cierre a través de prácticas rituales: Inicio de ceremonia deliberativa y jura sobre los acuerdos.

\section{El poder de nombrar: 1951}

Las Convenciones Constituyentes tienen el poder de dar nombre al nuevo territorio que se constituye, según la forma organizativa que adopte.

Estas marcas discursivas aparecen en los preámbulos:

"Nos los representantes de la Nación Argentina..."

"Nosotros, el Pueblo de los Estados Unidos, a fin de formar una Unión más perfecta..."

Estos modos de nombrarse a sí mismos y para reconocerse de otros, también existe en el preámbulo de las Constituciones provinciales.

En 1951, el preámbulo de la Provincia Presidente Perón expresaba:

"Nos los representantes del pueblo trabajador de la Provincia Presidente Perón..." Se designada con el nombre del líder del movimiento Peronista y por entonces presidente de la Nación, a la nueva provincia. 
La oratoria deliberativa, tiene rasgos y mixturas de la oratoria epidíctica. Siguiendo la definición aristotélica se ocupa de alabar y/o censurar. Por tanto, para esas acciones, lo digno de alabanza es la virtud.

El elogio es un discurso que pone ante los ojos la grandeza de una virtud. Conviene, presentar las acciones como propias de tal virtud.

En la argumentación del primer nombre: Provincia Presidente Perón y del segundo: Provincia del Chaco, se enfrentaron dos concepciones del constitucionalismo, de la Nación, de ciudadanía, de cultura. Esta lucha formuló en cada caso el triunfo de una facción sobre otra, y cada vencedor de esta contienda simbólica efectuó la acción de nombrar (1951) y renombrar (1957).

Esta acción es fundamental para entender la visión sobre los pueblos indígenas que llegaron hasta la sanción del artículo 34 de la Constitución reformada de 1994.

En la imposición de nombre, el tipo de oratoria predominante fue la epidíctica.

\section{A continuación los discursos que fundamentaron el nombre de Provincia Presidente Perón (diario de sesiones 1951):}

Convencional Felipe Gallardo:

"Señor Presidente: Me cabe el honor de haber sido designado por mis compañeros de tareas en esta Honorable Convención, para informar sobre las razones que hemos tenido para designar con el nombre Presidente Perón a esta nueva provincia argentina.

La resolución fue adoptada por unanimidad en reconocimiento a los innumerables beneficios recibidos por el pueblo trabajador de esta provincia y porque a un pueblo recio, tesonero y laborioso no podía encontrarse otro nombre más grato y adecuado que el del primer trabajador argentino.

La historia de esta provincia justicialista hasta el año 1943, nos muestra un pueblo olvidado por quienes estaban obligados a velar por su destino y bienestar.

Desde la campaña heroica de los primeros pobladores de este rudo a la vez generoso Chaco, hasta el advenimiento del gobierno justicialista del General Perón, hemos vivido relegados en el olvido y confiados a nuestra propia suerte, sin ningún amparo oficial y con una legislación deficiente. 
La mala organización del régimen político, social y económico se prestó admirablemente para la explotación capitalista liberal, que usó y abusó de nuestra economía, para beneficio de cerrados círculos privilegiados que se enriquecían con nuestro esfuerzo y nuestras penurias.

Los consorcios capitalistas y las grandes inversiones foráneas de franco tinte colonialista, se ingeniaban de modo de explotar al hombre y a la tierra misma, según conviniera a una larga cadena de inversiones diseminadas en todo el territorio de la Nación y, a veces, en otras regiones del mundo.

Así resultan hoy numerosas extensiones de tierras, verdaderos latifundios, condenados a no producir riqueza alguna, porque convenía más a los cálculos de los costos y los precios que esa producción no llegara a los mercados de consumo. Hoy, que los medios de transporte son argentinos, nos damos cuenta con qué criterio fueron trazados sus líneas y caminos, generalmente el más largo, costoso y menos adecuado a las necesidades internas; todo tendía a servir al extranjero y nuestra economía agraria y ganadera estaba condenada a esa servidumbre económica.

(..)

No teníamos derecho a elegir a nuestros gobernantes ni a intervenir o controlar la cosa pública; nuestro trabajo era una innoble mercancía; nuestra producción jamás alcanzaba precios remunerativos o compensadores de los sacrificios que había costado.

Nos decían que éramos libres, pero la única libertad que nos dejaban era la de morirnos de hambre.

Así aparece en el escenario de la Patria una gigantesca figura de estadista, el general Perón y con solo decir verdades y exponer un plan claro y sencillo para realizar una política argentinista y de justicia social, aglutinó a las masas y organizó la recuperación nacional.

El pueblo chaqueño, tallado en la dura madera de sus bosques y en los blancos algodonales de sus chacras, como sus conciencias limpias, se puso decidido a su lado y el premio a su fe y a su paciencia lo está gozando ahora, al ver su rápida transformación en un Estado argentino autónomo, al igual que sus hermanas, las otras provincias.

El general Perón logró para gloria de esta generación nuestra cristalizar con creces el sueño de los hombres de Mayo, de organizar una nación política y 
económicamente libre, ya que el primer trabajador argentino y nuestra primera abanderada, exhiben ante la humanidad una nación socialmente justa, económicamente libre y políticamente soberana.

¿Cómo no rendir entonces el más justiciero homenaje espiritual y cívico al más grande estadista y creador del justicialismo argentino, denominando a esta nueva provincia argentina que ha de cumplir un rol preponderando en el concierto federal de la Nación? Por esas razones es que la Honorable Convención Constituyente, en comisión, por unanimidad, ha resuelto denominar a este nuevo Estado argentino, provincia Presidente Perón”. 
Diario de sesiones. 1951

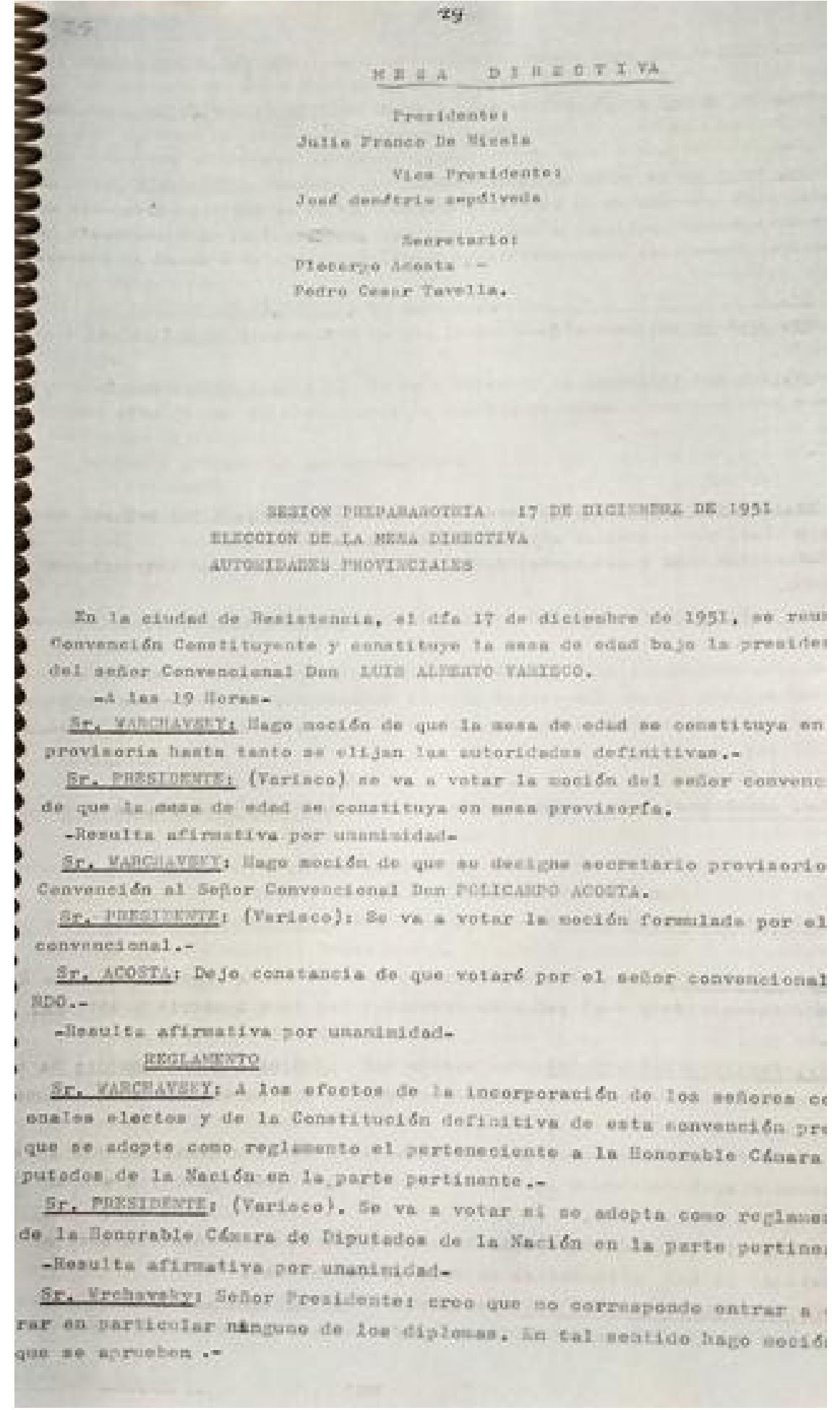




\begin{tabular}{|c|c|}
\hline ado del nombre: & \\
\hline $\begin{array}{l}\text { Relación de inclusión del pueblo } \\
\text { trabajador como un sujeto jurídico y } \\
\text { político. Avalado por el doble voto } \\
\text { sindical }\end{array}$ & $\begin{array}{l}\text {...los representantes del pueblo } \\
\text { trabajador de la Provincia Presidente } \\
\text { Perón. }\end{array}$ \\
\hline $\begin{array}{l}\text { Conciencias limpias convocadas por el } \\
\text { líder }\end{array}$ & $\begin{array}{l}\text { El pueblo chaqueño, tallado en la dura } \\
\text { madera de sus bosques y en los blancos } \\
\text { algodonales de sus chacras, como sus } \\
\text { conciencias limpias, se puso decidido a } \\
\text { su lado y el premio a su fe y a su } \\
\text { paciencia lo está gozando ahora, al } \\
\text { ver su rápida transformación en un } \\
\text { Estado argentino autónomo, al igual } \\
\text { que sus hermanas, las otras provincias. }\end{array}$ \\
\hline $\begin{array}{l}\text { Oratoria epidíctica: } \\
\text { Refuerza la relación trabajador-primer } \\
\text { trabajador asociado al Presidente Perón. }\end{array}$ & $\begin{array}{l}\text { La resolución fue adoptada por } \\
\text { unanimidad en reconocimiento a los } \\
\text { innumerables beneficios recibidos por } \\
\text { el pueblo trabajador de esta provincia } \\
\text { y porque a un pueblo recio, tesonero y } \\
\text { laborioso no podía encontrarse otro } \\
\text { nombre más grato y adecuado que el } \\
\text { del primer trabajador argentino. }\end{array}$ \\
\hline $\begin{array}{l}\text { Las masas agradecen al líder y rinden } \\
\text { homenaje con la imposición de su } \\
\text { nombre a la Provincia. }\end{array}$ & $\begin{array}{l}\text { ¿Cómo no rendir entonces el más } \\
\text { justiciero homenaje espiritual y cívico } \\
\text { al más grande estadista y creador del } \\
\text { justicialismo argentino, denominando a } \\
\text { esta nueva provincia argentina que ha } \\
\text { de cumplir un rol preponderando en el } \\
\text { concierto federal de la Nación? }\end{array}$ \\
\hline
\end{tabular}




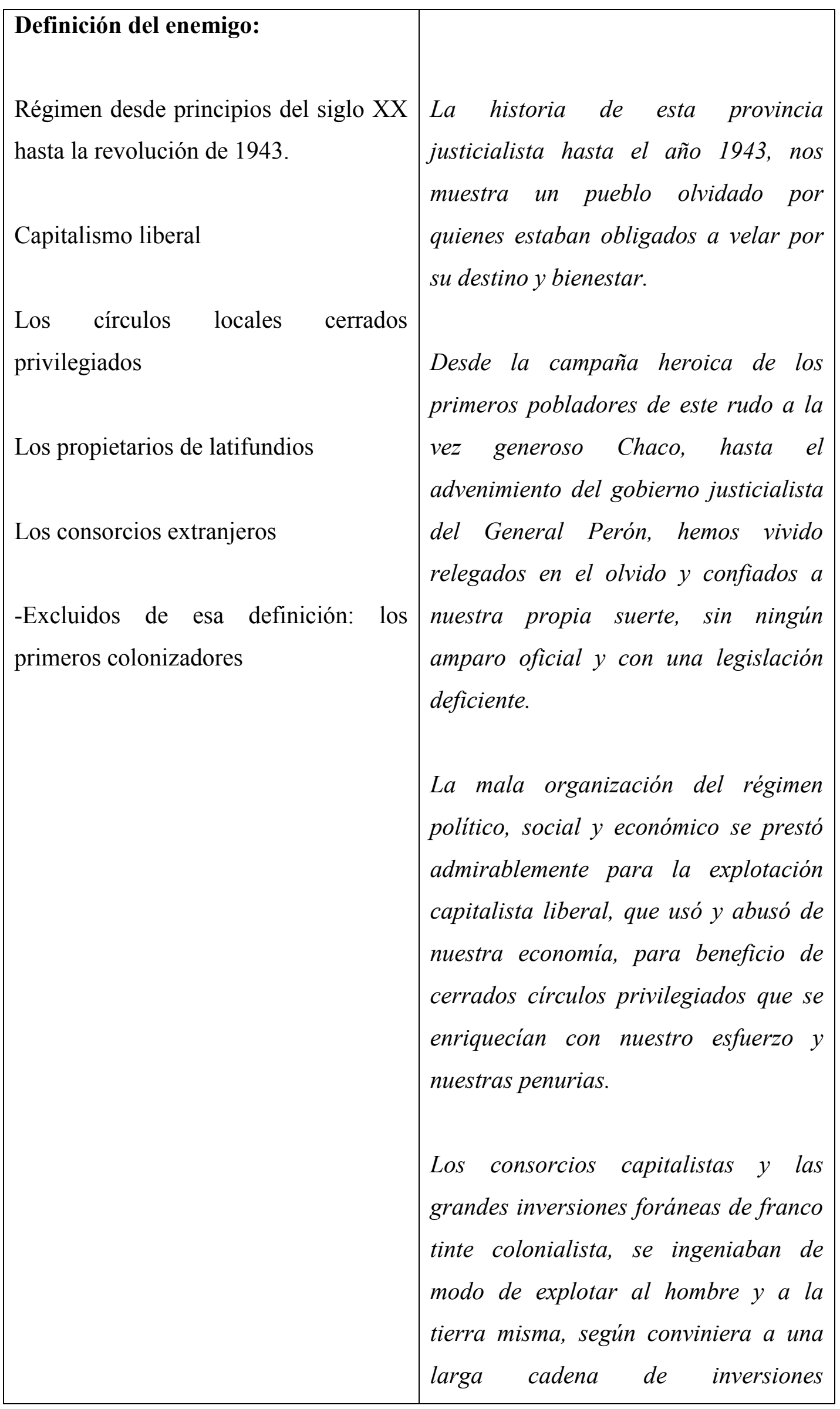




\begin{tabular}{|c|c|}
\hline & $\begin{array}{l}\text { diseminadas en todo el territorio de la } \\
\text { Nación y, a veces, en otras regiones del } \\
\text { mundo. } \\
\text { Así resultan hoy numerosas extensiones } \\
\text { de tierras, verdaderos latifundios, } \\
\text { condenados a no producir riqueza } \\
\text { alguna, porque convenía más a los } \\
\text { cálculos de los costos y los precios que } \\
\text { esa producción no llegara a los } \\
\text { mercados de consumo. }\end{array}$ \\
\hline Definición de amigo: & \\
\hline $\begin{array}{l}\text { Los que accedieron al voto, incluidas } \\
\text { las mujeres. Y al poder a través del voto } \\
\text { en } 1951 .\end{array}$ & $\begin{array}{l}\text { No teníamos derecho a elegir a } \\
\text { nuestros gobernantes ni a intervenir o } \\
\text { controlar la cosa pública; nuestro } \\
\text { trabajo era una innoble mercancía; } \\
\text { nuestra producción jamás alcanzaba } \\
\text { precios remunerativos } \\
\text { compensadores de los sacrificios que } \\
\text { habia costado. }\end{array}$ \\
\hline Los trabajadores explotados & $\begin{array}{l}\text { Nos decían que éramos libres, pero la } \\
\text { única libertad que nos dejaban era la } \\
\text { de morirnos de hambre. }\end{array}$ \\
\hline $\begin{array}{l}\text { Idea de Nación: } \\
\text { Política argentinista }\end{array}$ & $\begin{array}{l}\text {...un plan claro y sencillo para realizar } \\
\text { una política argentinista y de justicia } \\
\text { social, aglutinó a las masas y organizó } \\
\text { la recuperación nacional }\end{array}$ \\
\hline Justici & \\
\hline
\end{tabular}


Masas y recuperación nacional

Nación soberana y económicamente libre
El general Perón logró para gloria de esta generación nuestra cristalizar con creces el sueño de los hombres de Mayo, de organizar una nación política y económicamente libre, ya que el primer trabajador argentino y nuestra primera abanderada, exhiben ante la humanidad una nación socialmente justa, económicamente libre $y$ politicamente soberana.

\section{Constitución de la Provincia Presidente Perón}

La Constitución de la Provincia Presidente Perón surgió en el contexto de 1945 "cuando se institucionaliza el gremialismo a nivel nacional, los sindicatos- de ser factor de presión- pasan a actuar como factor de poder, especialmente desde 1951, momento en que se constituye la Provincia Presidente Perón” (Barreto: 2009) Para Barreto, “indígenas, paraguayos, inmigrantes, santigueños, conformaron la base de esa clase obrera que se presentaba con identidad propia a la historia nacional para asumir, desde 1943 en adelante, un proyecto político-sindical inédito en la Argentina. El mismo no hubiese sido posible sin esta trayectoria tan rica en conciencia y organización".

En términos discursivos, convoca la construcción de una identidad: la del "pueblo trabajador", tal cual se expresa en el preámbulo de la Constitución de 1951.

Esta era "la única clase de hombre" reconocida desde el sistema jurídico que debe ser interpretada desde su contexto, procurando la regulación de las relaciones económicas.

El 20 de diciembre de 1951 la Convención Constituyente reunida en el Chaco, de amplia mayoría peronista, aprobó la primera Constitución de la "Provincia Presidente Perón". La Constitución provincial replicaba los principios básicos de la Constitución de 1949, en el orden nacional y se ganaba, para algunos historiadores chaqueños, la definición de "corporativa", a raíz del establecimiento 
del doble voto sindical. Respecto de este punto, la Dra. Ana Rosa Farías de Foulkes, explicó, décadas después: “el voto doble no era ninguna novedad, existió siempre en Inglaterra, solo que al revés; eran los terratenientes, los grandes contribuyentes los que tenían el

privilegio del doble voto, lo que resulta natural, basándose en el principio de que los factores de poder debían tener más gravitación dentro del gobierno”(...) “En la Nación del norte también existen corporaciones bajo la forma de poderosos grupos de presión, sin embargo no tildamos a ese país de corporativista. ¿No será que rechazamos el estilo de gobierno de nuestro país por no ser "democrático" al estilo anglosajón? A mi juicio aún no se ha inventado el estilo democrático que debe regir en los países que tienen una idiosincrasia latinoamericana, cuyos habitantes, o cuya base social es tan diferente a la del país del norte"(Farías de Foulkes: 1996)

Para el convencional de 1951, Carlos Gro, de extracción gremial, el voto sindical era, en primer término, una innovación "que jerarquiza y dignifica la condición del trabajador" $y$, en segundo término, es un hecho revolucionario porque le asigna una participación real en la conducción de los destinos de la provincia al darle representación propia y obligatoria.

"No se trata señor presidente- dijo Gro a la Convención- de crear un privilegio; es simplemente un derecho al alcance de todos los trabajadores, en el sentido más amplio del vocablo, es decir, obreros,

empleados, industriales, comerciantes, médicos, abogados, trabajadores de cualquier rama del intelecto, que quieran seguir las sabias orientaciones de nuestro líder y se decidan organizarse cada uno dentro de la rama u oficio que les compete. Si así lo hicieran todos gozarían de la ventaja del doble voto, es decir, que a más de votar como ciudadano, aportará su voto sindical a la elección de compañeros que integrarán la Cámara de Representantes y desde cuyas bancas podrán los trabajadores lograr mayores conquistas sociales y consolidarán las existentes"(Gro: 1951)

La primera Constitución, daba status de provincia al entonces Territorio Nacional del Chaco. El impulso para la autonomía jurídica del territorio, emergía de las agrupaciones políticas- sindicales, nacidas en el liderazgo de Perón, no solo desde su proclamación como presidente en 1946 sino desde 1943, desde la Secretaría de Trabajo. 
Esta primera Constitución rigió desde 1951, pasando por la elección de gobernador y vice, en 1953, y la primera conformación de la legislatura provincial y la representación en el Congreso Nacional.

En la elección a la gobernación, el peronismo triunfó por el $80 \%$ de los votos de los chaqueños y chaqueñas, éstas últimas ingresadas al ejercicio de la ciudadanía a partir de 1951, llevaron a la gobernación en 1953 a la fórmula Felipe GallardoDeolindo Felipe Bittel. El radicalismo, tras el magro resultado obtenido en las elecciones para convencionales de 1951, se abstuvo de participar en las de 1953. Fue abstención, no proscripción.

Este primer gobierno constitucional fue derrocado en 1955.

\begin{tabular}{|c|c|c|}
\hline Matı & Propósitos pragmáticos & as discursivas \\
\hline $\begin{array}{l}\text { Modelo Retórico: oratoria } \\
\text { deliberativa }\end{array}$ & $\begin{array}{l}\text { Organización del Estado } \\
\text { social }\end{array}$ & $\begin{array}{l}\text { Incorporación de los } \\
\text { derechos del trabajador }\end{array}$ \\
\hline $\begin{array}{l}\text { Asunción/delegación del } \\
\text { "hombre trabajador" como } \\
\text { metáfora del "pueblo } \\
\text { trabajador" }\end{array}$ & $\begin{array}{l}\text { Regulación de las } \\
\text { relaciones económicas y } \\
\text { de propiedad }\end{array}$ & $\begin{array}{l}\text { Legisladores: Doble voto } \\
\text { sindical }\end{array}$ \\
\hline $\begin{array}{l}\text { Democracia } \\
\text { social/corporativismo } \\
\text { (desde la concepción } \\
\text { filosófica antagónica) }\end{array}$ & $\begin{array}{l}\text { No hay } \quad \text { "valores } \\
\text { absolutos", están sujetos } \\
\text { a las relaciones } \\
\text { económicas }\end{array}$ & $\begin{array}{l}\text { Representantes } \\
\text { pueblo trabajador }\end{array}$ \\
\hline
\end{tabular}




\section{El poder de nombrar: Provincia del Chaco (1957)}

El nombre Provincia Presidente Perón tuvo su primer cuestionamiento jurídico a un año de sancionada la Constitución de 1951. Generó una controversia relevante en términos de discursividad social Se presentó una demanda ante los tribunales federales para solicitar la "inconstitucionalidad de la Carta Corporativa, sancionada el 22 de diciembre de 1951, para la Provincial del Chaco presentada en mayo 1952 por los ciudadanos Guido Miranda, Darío Miró, Abraham Zeida, Enrique Kedinger y Edgardo Rossi”.

La misma fue tomada como argumento para justificar el cambio de nombre de "Presidente Perón" a "Chaco" en la Convención de 1957. También para la derogación de varios capítulos y artículos. La argumentación, en este caso es jurídica, consecuente con la idea de que el texto constitucional responde a ese género, que fue también expresar la idea latente que textos constitucionales no elaborados por juristas, tenían una falla de origen. Sumada a la falta de legitimidad que esta facción adjudicó a las elecciones de 1951 y 1953, cuando se eligieron, en la primera, convencionales constituyentes y en la segunda, al gobernador- vicegobernador y diputados.

A continuación, se presentan los argumentos principales del pedido de declaración de Inconstitucionalidad, denominada "Reivindicación del Chaco" (extraída de la versión taquigráfica de 1957)

\section{- Argumento histórico: Conquista y Colonización}

"Primer hijo de la Nación: es nuestro territorio el primer hijo que adquirió por derecho propio, por tesón y espíritu de sacrificio de los hombres de trabajo que lo poblaron, en magnífica comunión con la Nación, el derecho de compartir la igualdad constitucional reconocida para los estados provinciales. Ha merecido, mejor: ha conquistado el derecho cuya aplicación fuera injustamente postergada más allá de los términos fijados por la letra misma de la ley, reclamado largamente, a ser declarado provincia. Históricamente es el primer hijo de la Nación; el primer nuevo hermano de las Provincias Unidas del Río de la Plata; honor que hemos conquistado y que destacamos con orgullo los hombres del Chaco". 


\section{- Argumento político: Oposición al gobierno peronista}

"Pero la sensibilidad democrática y autonómica de los chaqueños señaló la inconveniencia o inoportunidad de insistir en tales gestiones, en el momento argentino posterior al movimiento militar triunfante en 1943. Se evidenció en el silencio de los grupos representativos y en la frialdad popular con que se recibió la ley tantas veces requeridas con anterioridad. Es que los pueblos libres no aceptan que se les conceda como una gracia, lo que merecen por derecho. Es que el pueblo consciente intuyó la insinceridad de los propósitos que habían puesto en movimiento la sanción de la ley, la que por este mismo defecto no podría cumlir la finalidad autonómica, verdaderamente federalizadora, ansiada por los pobladores del territorio y denegada por los hechos en la República, donde tenía ocasión de observar, con dolor, cómo las autoridades provinciales eran paulatinamente avasalladas. Mal podrían provincializarse los territorios en la hora en que se territorializaban las provincias".

\section{- Argumentos político-ético-legal- cultural: Falta de libertad y coacción}

“Son ilegítimos e inconstitucionales el preámbulo y los artículos $1^{\circ}$ y $7^{\circ}$ de la Constitución que designan a nuestra Provincia con el nombre de "Presidente Perón", solicitando se declare nula tal denominación que extraña la propia, tradicional e imprescriptible de "Chaco".

"Falta de libertad: En el primer encuentro con los aspectos jurídicos que os presenta la sustitución de nombre, nos asombra el triste papel de los que actuaron como convencionales, obligados a cumplir órdenes, carentes de libertad para pronunciarse. Surge aquí la primera causa de impugnación al extrañamiento del nombre, pues faltó libertad en el acto jurídico. Es primordial en derecho y principio básico del sistema representativo de gobierno, la facultad de obrar libremente".

"Para que un acto humano- político o jurídico tenga validez es condición esencial que el agente obre con libre determinación, dijo el doctor Alfredo Palacios acusando a los enjuiciadores de la Corte Suprema de la Nación, porque si mediara 
violencia o intimación para forzar la voluntad del que lo ejecuta, el acto es insanablemente nulo, como lo establecen nuestras leyes. En el caso ocurrente, aplicamos el concepto del ex Rector de la Universidad Nacional de La Plata: los convencionales chaqueños no se han decidido por la deliberada reflexión. Han sido presionados por las autoridades de una agrupación política y por el temor al desahucio.

Ese grupo de quince peronistas lanzados al acto electoral sólo recibió instrucciones de las autoridades superiores partidarias, por delegación del jefe, y solo a ellas debían rendir cuentas de su gestión. No se sentían responsables ni mandatarios de sus correligionarios chaqueños, ni del pueblo que los eligió. Las voces de protesta partidaria fueron silenciadas, pero los peronistas chaqueños se vengaron dejando a los convencionales en la más absoluta orfandad. Hubieron de reunirse solos, como avergonzados y a escondidas".

\section{- Cronotopo}

"En cinco días, tras profusos discursos de apertura y reiterados homenajes, sin discusión, se aprobó el proyecto confeccionado en alguna oficina pública, por personas que nunca pisaron nuestro territorio".

"Con estas circunstancias está demostrada, justamente la coacción que gravitó decisivamente sobre los actuantes".

\section{- Argumento jurídico: Falta de estudios previos}

"La falta de estudios previos, de consultas, de anteproyectos, de discusión pública, señala que no hubo de ponerse nada propio en debate, que todo había sido recibido hecho. Por ello mismo, no hubo deliberaciones, pues cada uno de los convencionales carecía de libertad para opinar. Apenas se trataba de protocolarizar la letra constitucional fraguada en alguna oficina políticoadministrativa...

En su favor, no se puede traer antecedente de inquietud o preocupación por estudios constitucionales, históricos o sociales de alguno de los 15 
convencionales. En el Chaco todos nos conocemos y todos sabemos que aquella nómina sólo trata de figuras apagadas o andodinas.

Pero donde la prueba alcanza su mayor validez es en la comparación de las Constituciones del Chaco y de La Pampa. Ambas son idénticas. Cotejados y comparados artículo por artículo, no se encuentra ninguna diferencia, salvo en la denominación ( $\mathrm{N}$ de E: La Pampa se denomin \{o “Provincia Eva Perón) y en el artículo 33. Surge fehacientemente que ambas convenciones recibieron la orden de consagrar idéntico texto.

Como se aprecia, nuestra Constitución provincial es el resultado de la coacción, por lo tanto está viciada de nulidad".

\section{- Argumento moral: Cuestionamiento del nombre Presidente Perón y tiranía de Rosas}

"Es indigna y ajena al modo de ser argentino la pretensión de inmortalizar a quien dispone del poder y de la fuerza, en el mismo instante que éstos se ejercen, anticipándose al juicio de la historia, cuya firmeza es obra no de la actualidad sino de la posteridad. Es deshonor que califica como traición a la Patria.

En efecto, en el artículo 20 de la Constitución Nacional está definitivamente estampado el juicio de la historia para los tiranos que pretendieron o pretendieran glorificarse en vida. Dice así: "El Congreso no puede conceder al Ejecutivo Nacional, ni a las Legislaturas Provinciales a los Gobernadores de Provincias, facultades extraordinarias, ni la suma del poder público, ni otorgarles sumisiones o supremacías por las que la vida, el honor o la fortuna de los argentinos quede a merced de gobiernos o persona alguna. Actos de esta naturaleza llevan consigo una nulidad insanable, y sujetarán a los que los formulen, consientan o firmen, a la responsabilidad y penas de los infames traidores a la Patria”.

"Y concluiremos que en el afán de alabanzas desmedidas, agotado el léxico de los elogios, se menospreció el honor de un pueblo, subordinando su nombre a la merced de un hombre viviente con función presidencial. Los convencionales peronistas han otorgado al Presidente de la República, en ejercicio, la sumisión del nombre auténtico de un territorio argentino, han puesto bajo la supremacía de 
su jefe político la sustantivación y adjetivación patronímica de una provincia y sus habitantes".

"Interpretamos la valoración de las palabras sumisiones y supremacías que emplea el artículo, a la luz del origen histórico y propósito de prevención que lo anima. "Nunca son excesivas- enseñaba Estrada, comentando esta disposición constitucional- las precauciones de las sociedades en el resguardo de sus derechos, de su autonomía, de su orden legal y de la paz interna y no son cautas las que cuentan con la bondad de los que han de ejercer el poder, sino que deben precaverse de su maldad".

Agrega que este artículo, "Aunque no tuviera ninguna explicación satisfactoria en el terreno teórico tiene una explicación histórica". El tirano Rosas usó y abusó totalmente de las facultades, poderes, sumisiones y supremacías condenadas por la ley natural y por el pundonor de los argentinos. Los constituyentes del 53 (1853) creyeron necesario hacer docencia cívica "añadiendo todas las vergonzosas denominaciones que la monstruosidad prohibida recibió en aquella época infanda". Y termina elocuente: "Tal es el origen de este artículo. Mirémosle con respeto: está escrito con la sangre de nuestros hermanos..."

"Reléase la crónica de los días de Rosas y saltará a la mente un retablo de abyección y bajeza que torna afrentosos los alcances de la sumisión. Afronte con franqueza el argentino actual el panorama político- social de la República y dígase si la situación del nombre histórico de un Estado argentino, no viene a constituir un hecho más, en cierto ambiente cargado ya de una característica proclividad rosista. No son imposibles las comparaciones con la época de la Tiranía”.

\section{- Argumento político: Origen del nombre Chaco y conquista}

“Transladándonos a los testimonios originales de los descubridores, conquistadores o colonizadores de la tierra, es decir, dejando de lado las versiones y comentarios que tejió la historiografía con el análisis y la interpretación de los mismos, descubrimos que el nombre del Chaco fue aplicado en los primeros tiempos de su uso, precisamente a la región montuosa donde hoy se confunden los límites de Salta, Formosa y Chaco. Enrique de Gandía había establecido ya que la 
palabra aparece por primera vez en un recibo firmado por el capitán Pedro de Lasarte, en Santiago del Estero, el 17 de septiembre de 1591, por dinero y materiales de guerra para el descubrimiento del "chaco gualamba", protocolizado en la ciudad de La Plata (Perú colonial), el 23 de septiembre de 1594, por la información de servicios del Gobernador de Tucumán Juan Ramirez Velazco”.

"El nombre de Chaco Gualamba era aplicado por Ramírez a una región geográfica y por Argañaraz a una nación etnográfica, fenómeno común en la época, que originó como veremos más adelante el mito del Gran Chaco Gualamba. Según Antonio Serrano la terminación "gualamba" es una desinencia propia del idioma o dialecto de los lules.

-"La ciencia etnográfica actual ubica de una manera evidente los contornos del primitivo Chaco Gualamba: Tonocotés, eran por otra parte los 20.000 aborígenes que descubrió Alonso de Vera y Aragón en Matará y también los pobladores de Guácara, encomendados a Antón Martín, vecino de Esteco”.

"Las tribus guaycurúes (chaquenses típicos) encararon el renacimiento de la estirpe nativa: los lules, tonocotés, vilelas, desaparecieron ensombrecidos por los mocovíes, abipones y tobas y en pocos años los españoles abandonaron los llanos extendidos entre los ríos Paraná y Salado y perdieron la noción de sus lindes geográficos".

"Las ciudades de la corriente colonizadora del Norte: Jujuy, Salta, Esteco, se veían obligadas a enfrentar terribles malones. Concepción del Bermejo fue arrasada en 1632; Corrientes, Santa Fe y Córdoba vieron llegar mocoviés y abipones a los umbrales de sus poblaciones y en esa carta al Rey del Gobernador de Tucumán, Angel de Peredo, fechado 1673, se lee: “ser este genttio el mas barbaro y Ynculto q se a reconosido en todas estas provincias..." Por otra parte en 1691 decía el arzobispo de Charcas al acusar recibo de una Real Cédula: "También tengo por inútil al medio embiarle misiones por ahora:porque los dos Csacos están insolentes y los pasarán a cuchillo (dixit)" 


\section{- Argumentos político- económico: Epopeya civilizatoria, Estado Nacional y Régimen de tierra pública}

"En "Noticias históricas y descriptivas sobre el gran país del Chaco y Río Bermejo", del coronel José Arenales, editado en 1933. Abatida la tiranía de Rosas y concluida la guerra del Paraguay, Domingo Faustino Sarmiento crea el gobierno del Chaco, por decreto del 30 de enero de 1872. El Congreso, por ley número 576 del 16 de octubre del mismo año respalda el primitivo decreto de Sarmiento y establece que el territorio del Chaco "será regido por un Gobernador, por jueces de paz y por comisionados municipales". El Coronel Manuel Obligado, animado por Sarmiento, comienza a avanzar la frontera militar en el norte de la provincia de Santa Fe, y "empieza así para nuestro país y para esta parte de América (el Gran Chaco) la segunda creación, es decir, su posesión por la ciencia, su fecundización por la inteligencia humana", dice Nicolás Avellaneda en el estudio sobre "El Gran Chaco" de Luis J. Fontana.

"Una región como la del Chaco sólo será debidamente explorada por la colonización; asevera Avellaneda en otra parte del ensayo y bien sabemos qué significaba "colonización" para el ilustre autor de "El Régimen de la Tierra Pública"

“El artículo 100 de la Ley 567 establecía la cesión de tierras a "todo individuo nacional o extranjero, jefe de familia o mayor de veintidós años con intención de entrar a poblarla y cultivarla", anticipando las bases de la ley de inmigración y colonización Número 817 del 19 de octubre de 1876, en la que a su vez se confirmaba para los colonos, cualesquiera fuese su origen, el derecho a constituir la municipalidad, cuyas funciones abarcaban "todo lo relativo a instrucción pública, registro del estado civil de las personas, higiene y parte económica y policial", de acuerdo con lo cual, cinco colonos extranjeros, nombrados por el General Antonio Dónovan, constituyen el primer Consejo Municipal de Resistencia el 9 de enero de 1884, creando una generosa tradición local de convivencia liberal que ha pasado a sustanciarse con el derecho público de los Territorios Nacionales". 


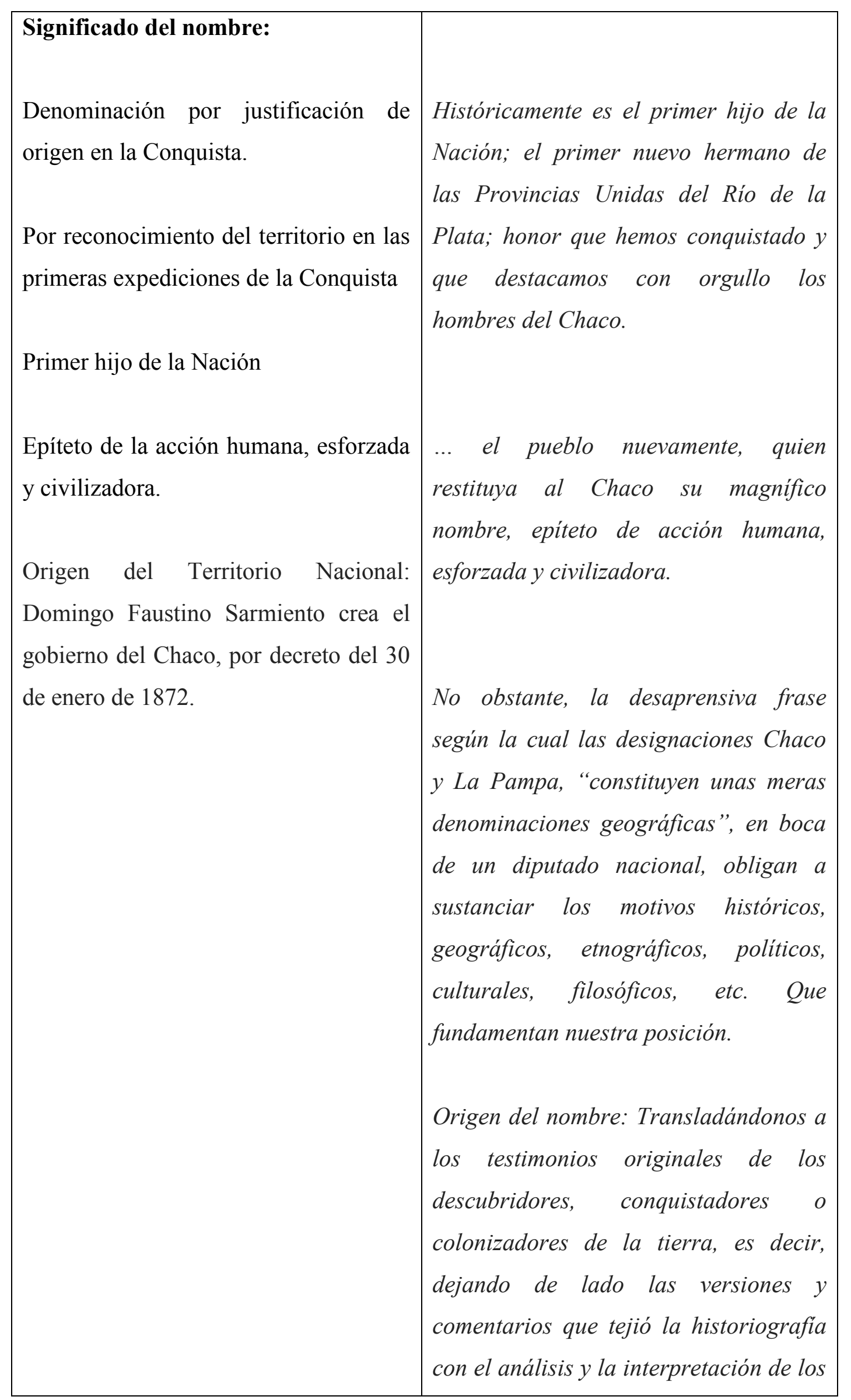




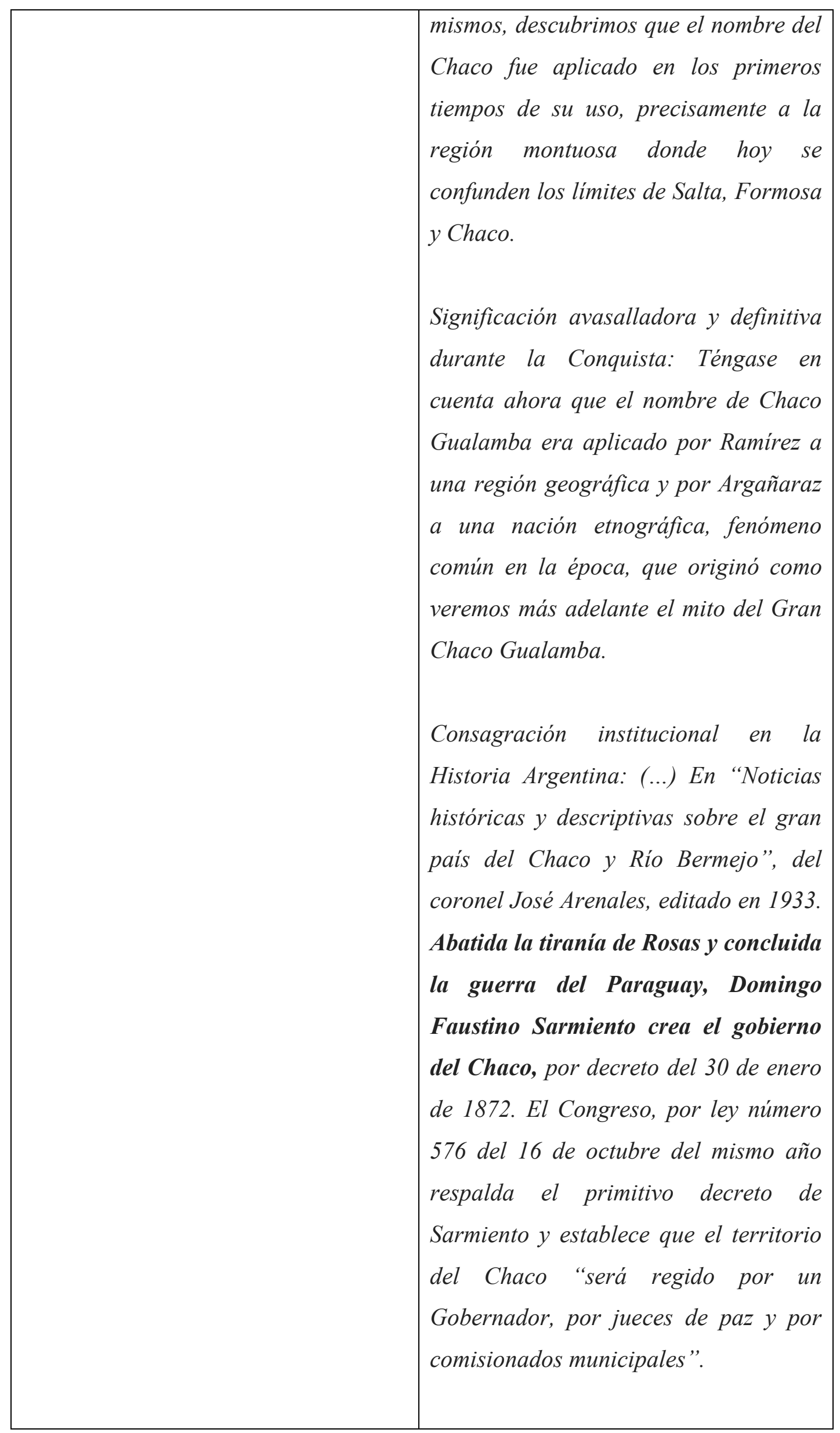




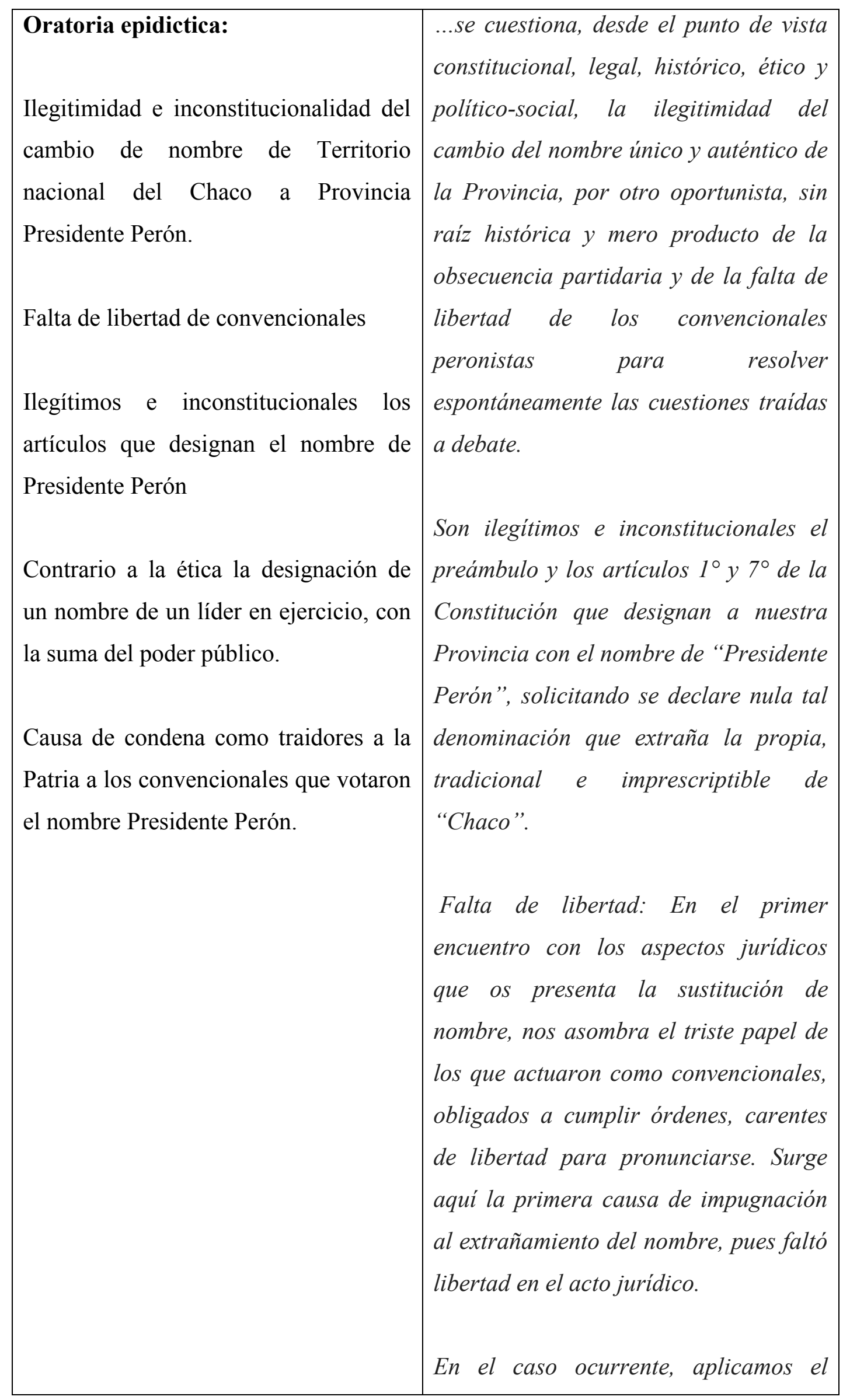




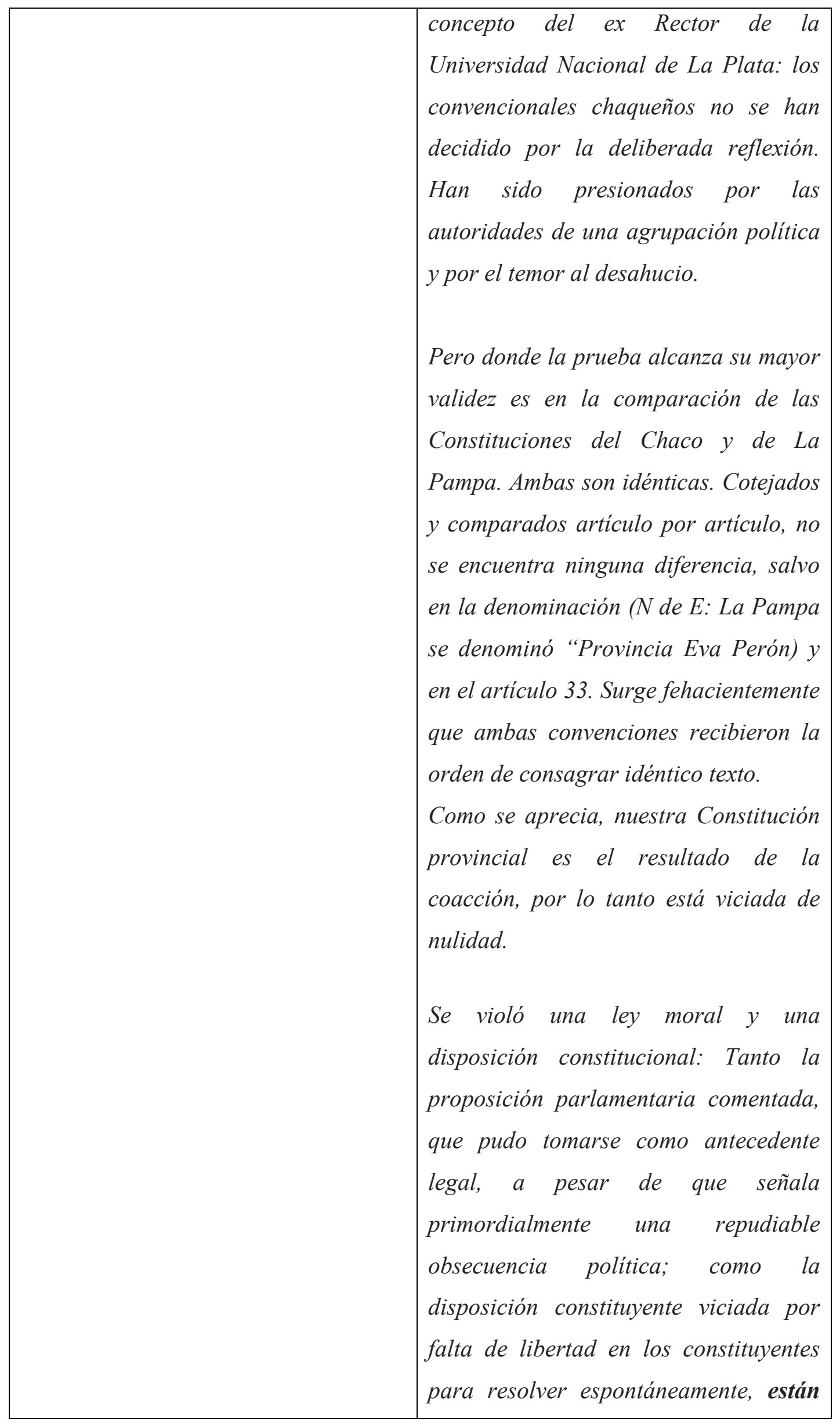




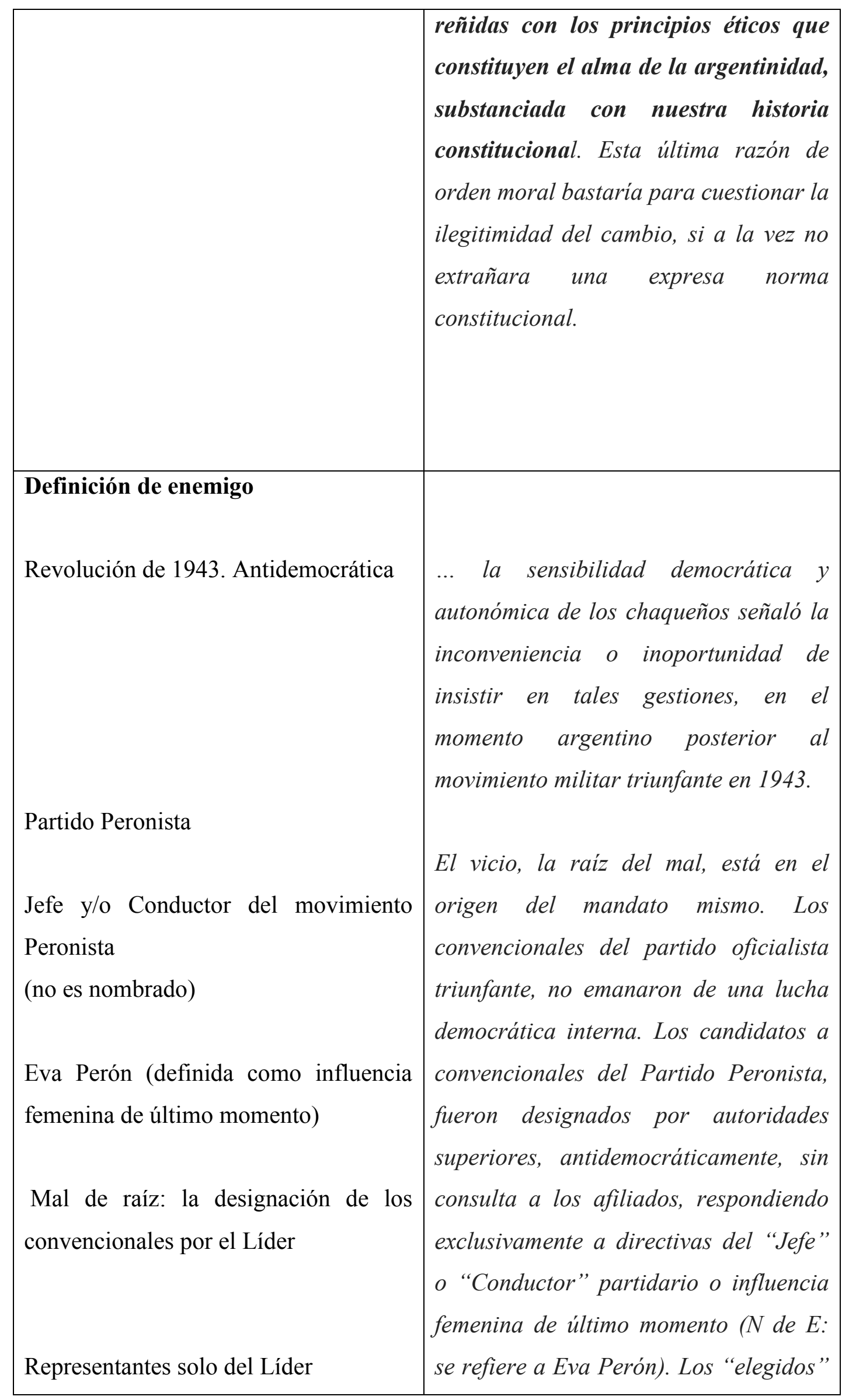




\begin{tabular}{|c|c|}
\hline $\begin{array}{l}\text { Reunión a escondidas y en cinco días, } \\
\text { sin fundamentación jurídica. }\end{array}$ & $\begin{array}{l}\text { y el sector peronista chaqueño, fueron } \\
\text { los primeros sorprendidos por la } \\
\text { designación, cuando les fue } \\
\text { "comunicada" la lista de candidatos. }\end{array}$ \\
\hline $\begin{array}{l}\text { Desprecio por el origen social de los } \\
\text { convencionales } \\
\text { peronistas }\end{array}$ & $\begin{array}{l}\text { Ese grupo de quince peronistas } \\
\text { lanzados al acto electoral sólo recibió } \\
\text { instrucciones de las autoridades } \\
\text { superiores partidarias, por delegación } \\
\text { del jefe, y solo a ellas debían rendir } \\
\text { cuentas de su gestión. }\end{array}$ \\
\hline Traidores a la Patria & $\begin{array}{l}\text { Hubieron de reunirse solos, como } \\
\text { avergonzados y a escondidas. En cinco } \\
\text { días, tras profusos discursos de } \\
\text { apertura y reiterados homenajes, sin } \\
\text { discusión, se aprobó el proyecto } \\
\text { confeccionado en alguna oficina } \\
\text { pública, por personas que nunca } \\
\text { pisaron nuestro territorio. } \\
\text { En su favor, no se puede traer } \\
\text { antecedente de inquietud } \\
\text { preocupación por } \\
\text { constitucionales, históricos o sociales } \\
\text { de alguno de los } 15 \text { convencionales. En } \\
\text { el Chaco todos nos conocemos y todos } \\
\text { sabemos que aquella nómina sólo trata } \\
\text { de figuras apagadas o andodinas. }\end{array}$ \\
\hline & $\begin{array}{l}\text { Es indigna y ajena al modo de ser } \\
\text { argentino la pretensión de inmortalizar } \\
\text { a quien dispone del poder y de la }\end{array}$ \\
\hline
\end{tabular}




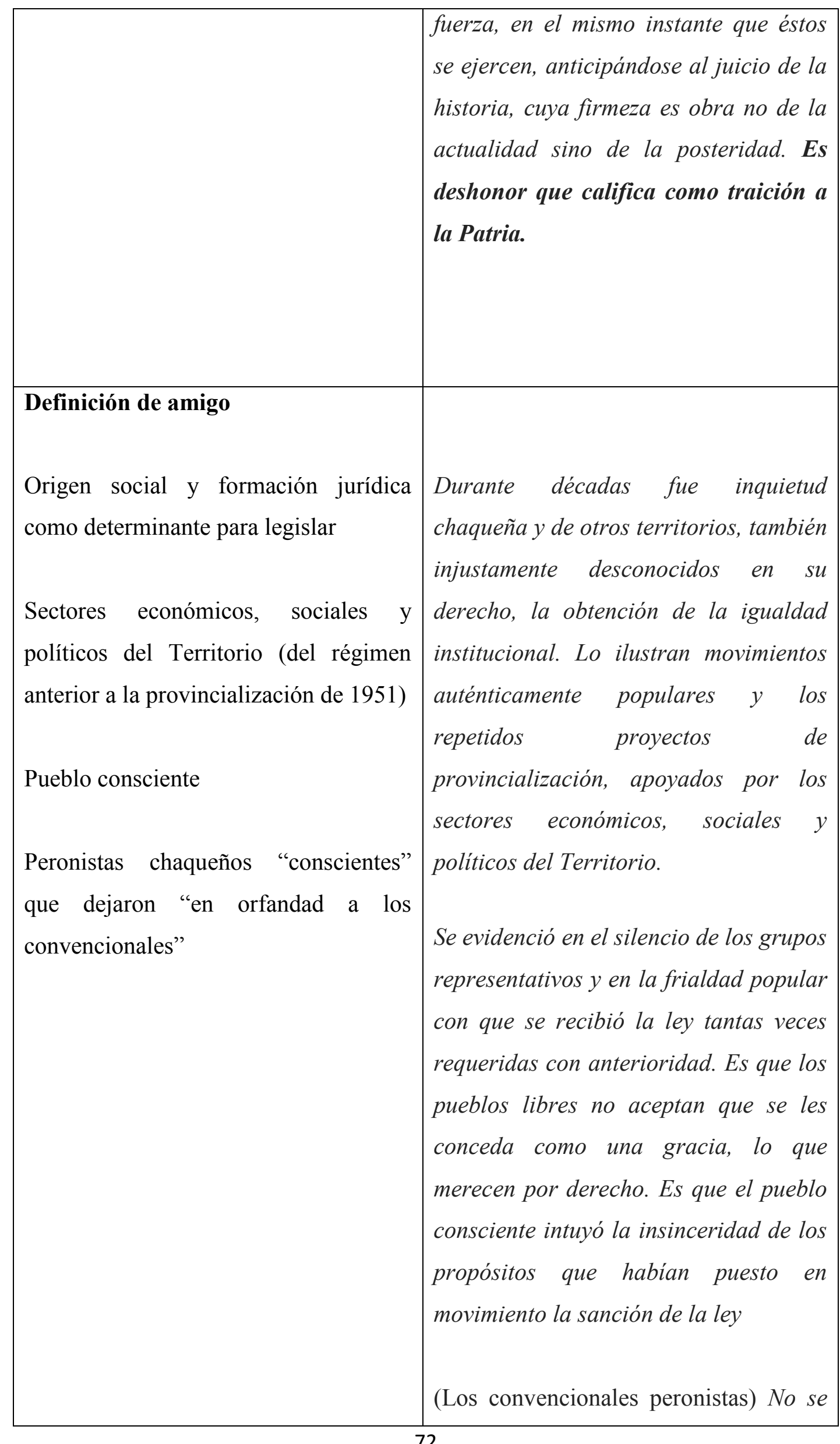




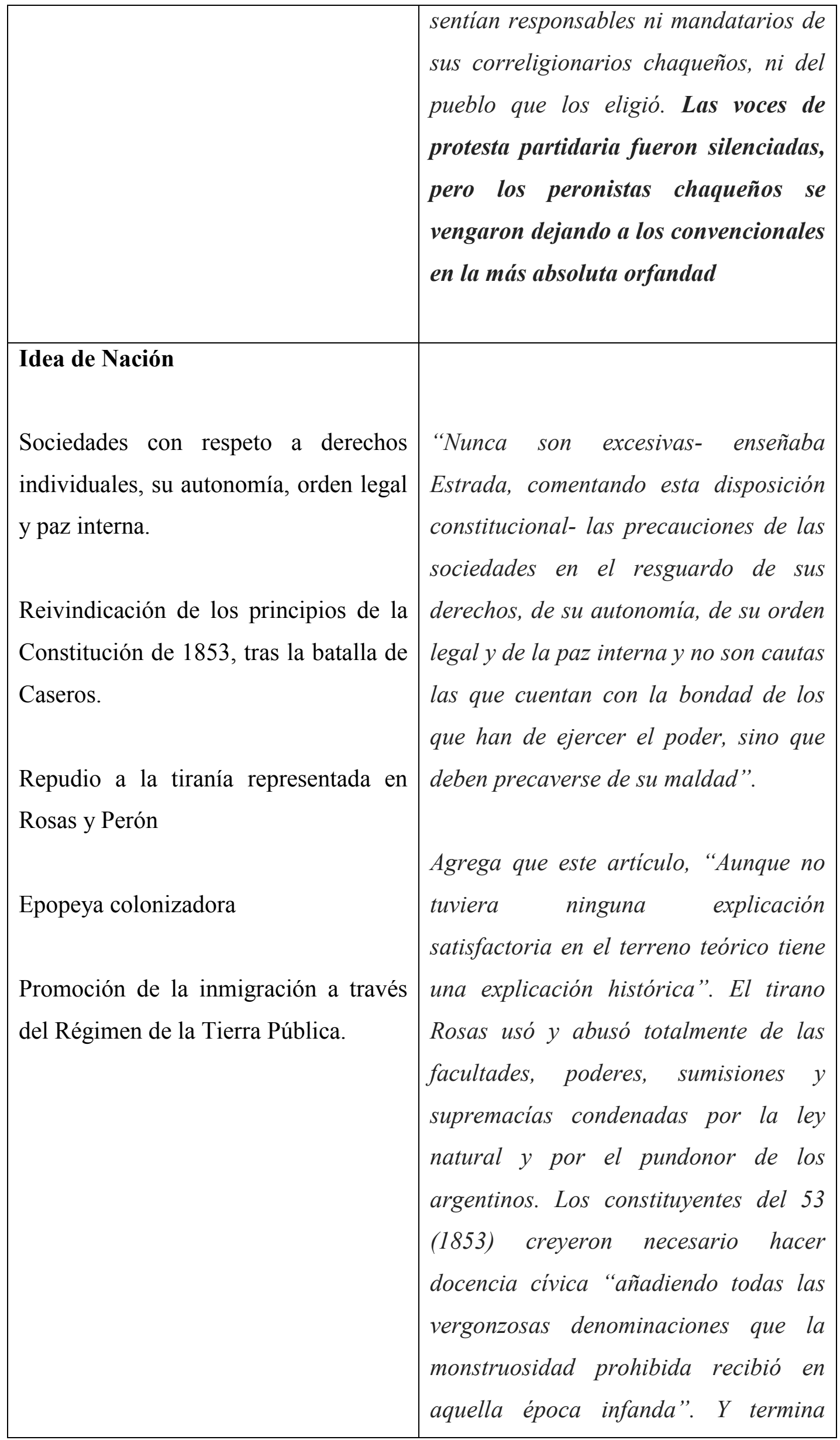




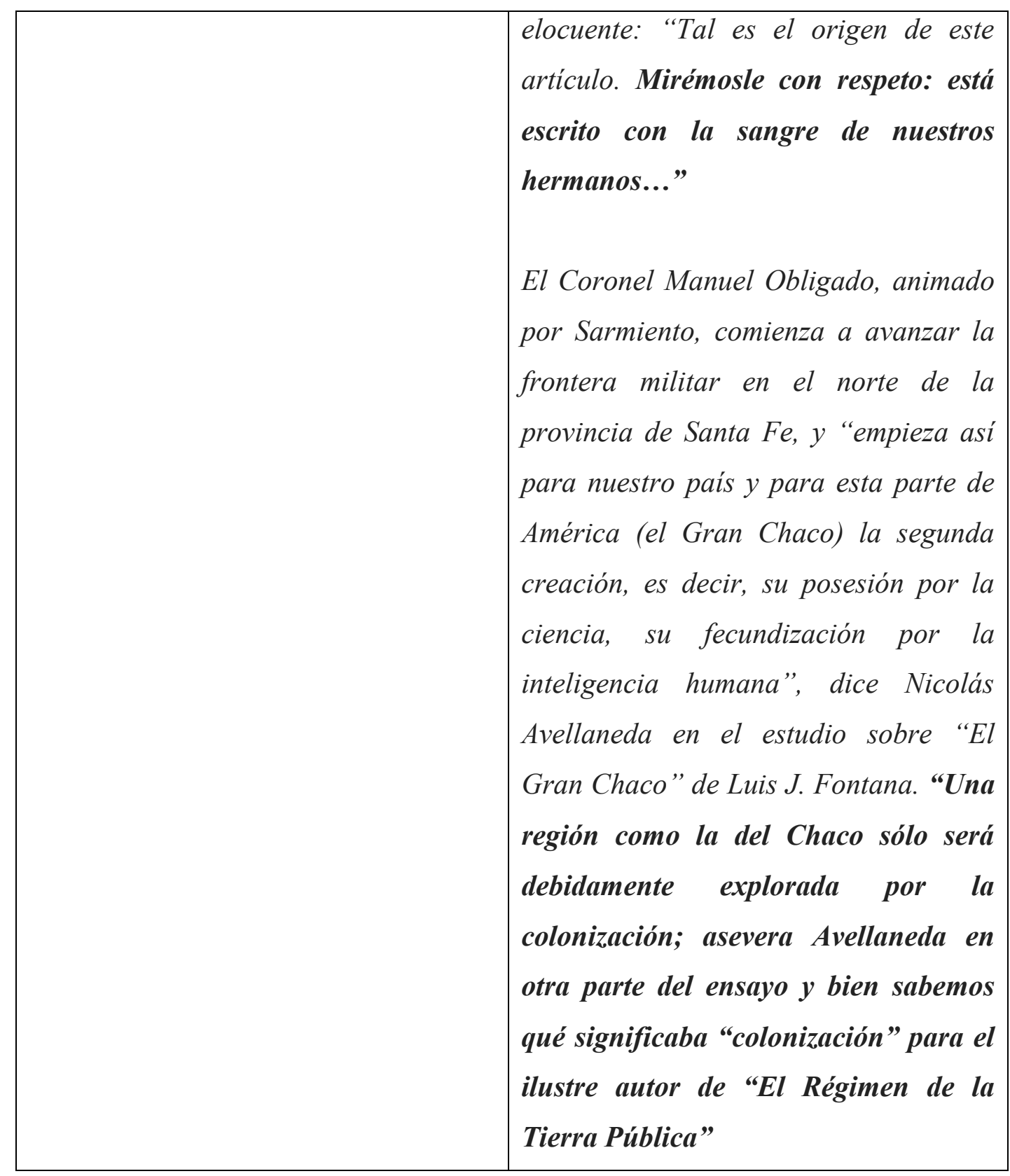


Diario de sesiones. 1957

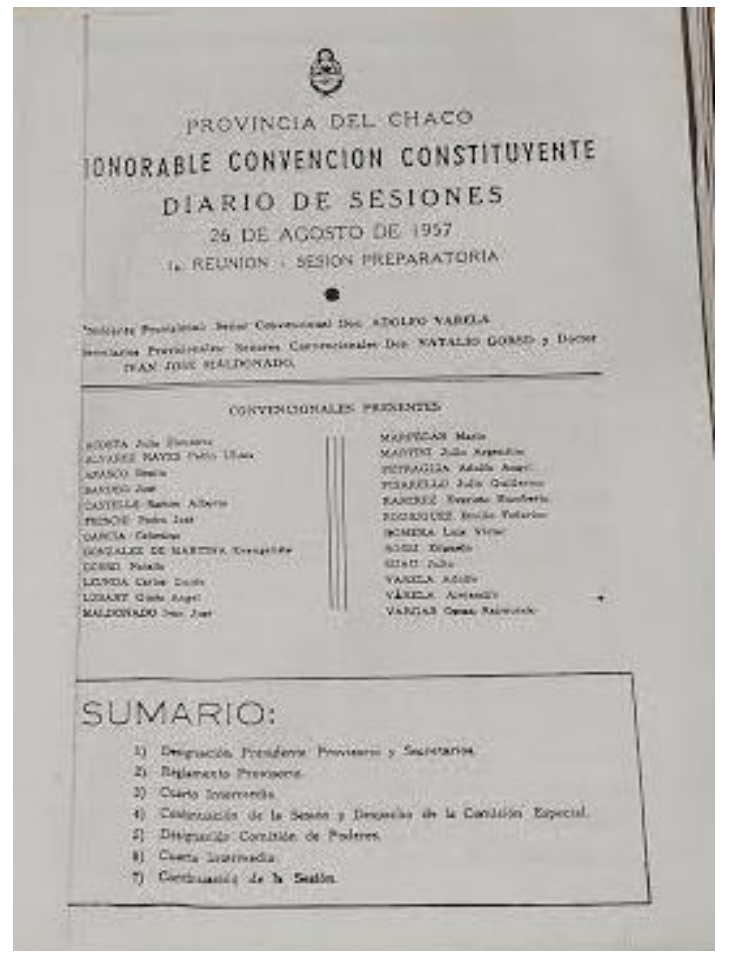




\section{La Constitución de 1957}

"El 7 de diciembre de 1957 se sanciona en el Chaco una nueva Constitución, ahora en total antítesis con la anterior con legisladores del conjunto de los partidos no peronistas. La composición de la nueva constituyente era dominantemente del partido radical y socialistas, los primeros tradicionalmente representantes de los productores agrarios y los socialistas portadores del ideario cooperativista quienes veían en estas organizaciones los gérmenes del "socialismo sano" en oposición a las corrientes marxistas. De esa forma, el cooperativismo agrario impone su "buen sentido" en la letra de la Constitución de la Provincia en tres artículos: El $38^{\circ}$ referido a la tierra pública -adjudicaciones preferenciales a las cooperativas-; el $41^{\circ}$ de Defensa de la Producción Básica y el $47^{\circ}$ de promoción y favorecimiento de la Cooperación Libre. Es decir, se impone en la letra de la constitución del Chaco el ideario que constituía la hegemonía de la pequeño burguesía agraria agrupada en cooperativas” (ROZÉ: 2007)

Podríamos concluir, siguiendo a Rozé, que se había dado forma discursivajurídico-política a la territorialidad, con la constitución del nuevo "Estado Provincial"

Este nuevo estado provincial, inaugurado tras el derrocamiento del peronismo, configuraba otras herramientas, como el Banco de la Provincia del Chaco, cuya actuación sería central décadas después para las políticas de Estado orientadas a la dirección económica- financiera de la provincia durante la dictadura de 1976 y posteriormente, en un período que no abordaré como el Estado provincial endeudado de la globalización.

El movimiento cooperativista tiene larga tradición en el Chaco. Reportó Guido Miranda que "en 1920, el director de la escuela de Margarita Belén, Francisco Agostini, en compañía de varios agricultores del lugar, funda una asociación para vender colectivamente el algodón en bruto o desmontado, con el propósito de sortear la depresión provocada por la caída de los precios de la primera guerra mundial. Al mismo tiempo, el director de la escuela de Laguna Blanca, Tristán Iglesias, estimula una fuerte corriente de opinión en idéntico sentido, en las colonias que rodean Puerto Tirol, donde Antonio Címbaro Canella, 
con el concurso de varios vecinos destacados, crea la "Sociedad de Fomento Agrícola Ganadero". Con la intuición propia de su característico talento Enrique Lynch Arribálzaga, entonces Presidente de la Federación de Sociedades Agrícolas del Territorio, convoca en Resistencia una memorable asamblea de agricultorescon la asistencia del gerente de la sucursal del Banco de la Nación Argentina apellidado Duarte Díaz- que decide la transformación de aquellas entidades en Cooperativas Agrícolas Industriales. Sin énfasis ritual ni ceremonias rumbosas surge la comunión de un grupo de pobladores que están dispuestos a marchar hombro con hombro, para respaldar no ya el nacimiento de una ciudad sino la ocupación del Territorio" (MIRANDA: 1955)

\begin{tabular}{|c|c|c|}
\hline Matriz discursiva & Propósitos pragmáticos & Estrategias discursivas \\
\hline $\begin{array}{l}\text { Modelo Retórico: oratoria } \\
\text { deliberativa }\end{array}$ & $\begin{array}{l}\text { Organización del nuevo } \\
\text { Estado territorial- } \\
\text { agrario }\end{array}$ & $\begin{array}{l}\text { Ideario constituyente de la } \\
\text { hegemonía de la pequeño } \\
\text { burguesía agraria agrupada } \\
\text { en cooperativas }\end{array}$ \\
\hline $\begin{array}{l}\text { Asunción/delegación de la } \\
\text { "libre cooperación", } \\
\text { cooperativas de } \\
\text { producción primaria }\end{array}$ & $\begin{array}{l}\text { Regulación de las } \\
\text { relaciones económicas } \\
\text { y de propiedad }\end{array}$ & $\begin{array}{l}\text { Legislación para los } \\
\text { "pobladores/ocupación de } \\
\text { territorio" }\end{array}$ \\
\hline $\begin{array}{l}\text { Democracia } \quad \begin{array}{c}\text { de } \quad \text { la } \\
\text { pequeña } \\
\text { primaria }\end{array} \\
\text { burguesía }\end{array}$ & $\begin{array}{lcc}\text { "Socialismo } & \text { sano" } & \text { en } \\
\text { oposición } & \text { a } & \text { las } \\
\text { corrientes marxistas }\end{array}$ & $\begin{array}{l}\text { Representantes de los } \\
\text { productores agrarios }\end{array}$ \\
\hline
\end{tabular}


MAPA DEL CHACO- 1951- Extraído de los documentos personales del primer Gobernador Felipe Gallardo. 


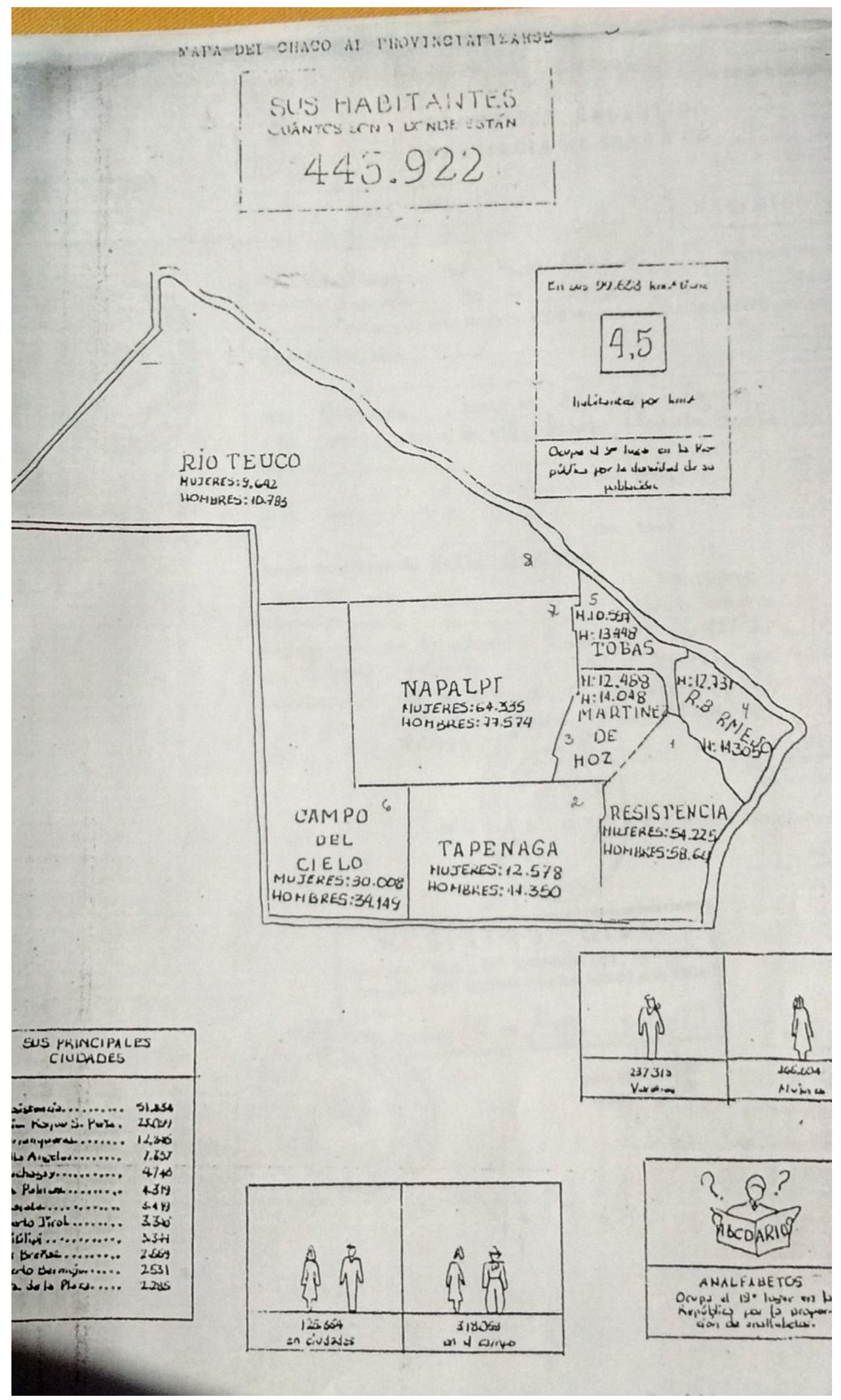




\section{2) Régimen de verdad y régimen discursivo: Las Constituciones como género deliberativo}

\section{Debates constituyentes en la Argentina: "Donde están los bienes económicos está la patria”(J.B.Alberdi)}

Los debates constituyentes del siglo XIX y XX, en la Argentina, emergieron ante ciertas condiciones de producción discursiva que posibilitaron el "game" de otros actores, cuya presencia construyó antagonismos y alianzas, como interacciones pragmáticas, es decir estratégicamente orientadas a un fin.

La convención Constituyente, se presentó, en la presente investigación, como género en una tragedia, ordenada en capítulos, organizando la participación de actores y ofreciendo un acto final que pudiese clausurar, por vía de la democracia representativa, los distintos conflictos entre actores, hasta cerrar un epílogo, provisorio, como todo texto, pero consensuado, entendiendo al consenso en su acepción de policity.

La prensa gráfica fue un actor en este proceso puesto que, conforme a sus reglas de estructuras y géneros presentó el debate en términos periodísticos.

El debate constitucional se caracterizó por clasificar principios, deberes y derechos para organizar un Estado de Derecho. Las diferentes facciones políticas pugnaron por una victoria y para ello recurrieron a estrategias persuasivas, hasta lograr sus fines o un acuerdo sobre ellos.

El debate parlamentario/constitucional es un tipo de discurso de poder que "marca los límites entre lo que puede ser nombrado y lo que no" (FOCAULT: 1980).

El discurso es un hecho, una materialidad y sobre esa materialidad se desarrollan las pujas, argumentos y proposiciones orientadas a un fin.

En los términos de este trabajo, discurso y poder fueron cara y contracara.

"Los códigos fundamentales de una cultura-los que rigen su lenguaje, sus esquemas perceptivos, sus cambios, sus técnicas, sus valores, la jerarquía de sus prácticas- fijan de antemano para cada hombre los órdenes empíricos con los cuales tendrá algo que ver y dentro de los que se reconocerá. En el otro extremo del pensamiento, las teorías científicas o las interpretaciones de los filósofos 
explican por qué existe un orden general, a qué ley general obedece, qué principio puede dar cuenta de él, por qué razón se establece este orden y no aquel otro".

Las condiciones discursivas, como productoras de símbolos y creencias desde el capitalismo fueron objetivaciones producto de un poder y de una cosmovisión. No las únicas. El antagonismo, en términos de discursividad social, se presentó de diferentes modos, esta regla/convención discursiva cambia según sus condiciones de producción discursiva: no son las mismas en cada sociedad.

En este caso, la relación y regulación de la propiedad fue constituida y normada desde el Derecho, siendo éste uno de los primeros discursos fundantes,

\section{Contexto histórico, político, social, económico de las Constituciones de 1951, 1957 y 1994}

- Bases y puntos de partida para la organización política de la República Argentina

Juan Bautista Alberdi, en su exilio chileno, escribió Bases y puntos de partida para la organización política de la República Argentina, en 1852 y que después acerca al vencedor de Caseros, el General Justo José de Urquiza. "Ése es por ende el momento decisionista de Alberdi, el momento en que el legislador pronuncia una palabra y en que esa palabra se convierte en ley" (TERÁN: 2009)

El constitucionalismo de Alberdi, consumado en la Constitución Argentina y las de las Provincias, se orientó a la economía.

“Alberdi piensa que la economía, en ese estadio de república imperfecta, es el ámbito de los derechos universales. Sobre esto vuelve una y otra vez en las Bases, hay que dar todo tipo de garantías y derechos para que los individuos desplieguen sus prácticas económicas. En cambio, la política es el universo de los derechos restringidos" (TERÁN: 2009).

"Es necesario distinguir entre dos tipos de nacionalismo: el constitucionalista y el culturalista. En cuanto a Alberdi, es claro que profesa un nacionalismo constitucionalista, si entendemos por éste el que sostiene que la pertenencia de una nación se define por la adhesión a la Constitución de un país en tanto código que establece las leyes fundamentales que regulan aquellos derechos naturales y por ende universales: libertad, propiedad, seguridad, etc. 
(...) Estampará una frase aún más provocativa para los futuros estándares nacionalistas: "Ubi bene, ibi patria ("Donde están los bienes económicos está la patria). (...) Ha cedido en pro de la influencia economista de Adam Smith (...) Alberdi escribe: "La libertad, como los ferrocarriles, necesita de maquinistas ingleses" (TERÁN: 2009)

Introduce la idea que los hábitos son los que modificarán las costumbres y no la instrucción letrada formal. "La educación por las cosas", siguiendo a Rosseau.

La República Argentina no varío los principios fundamentales de la Constitución de 1853. La Convención reformadora de 1994, surgida del Pacto de Olivos, abordó un núcleo de coincidencias entre las que se destacan la reelección presidencial, el cambio del período presidencial a 4 años, la privatización de los servicios públicos, como núcleos dramáticos, en términos discursivos.

Para corroborar que fue la matriz económica la que determinó la Constitución argentina, se evidenció que en 1869 fue sancionado el Código Civil (Vélez Sarfield), que regula las relaciones entre individuos, contratos y propiedad.

En tanto, recién en 1922, se sancionó el Código Penal.

Esta genealogía confirma que el principio de organización constitucional y su matriz de comunicación, por vía del Derecho, se orientan regular las relaciones de propiedad.

Todas las Constituciones provinciales, por principio de pirámide jurídica, deben atenerse a esos principios.

Salvo la Constitución de 1949, abolida por Bando militar.

A la fecha del presente trabajo- 2016- rigen las Bases y principios pensados por el primer legislador: Juan Bautista Alberdi, en sus conceptos fundamentales y fundacionales.

- Diferencias y similitudes entre la Constitución Argentina de 1853 y la de Estados Unidos de América

El sentido de este apartado fue distinguir la discusión sobre la influencia de la Constitución norteamericana sobre la de la República Argentina. Si bien se reconoce que fue antecedente para los países de América por ser la primera, también ameritó marcar los rasgos distintivos. 
La diferencia fundamental entre ambas Constituciones es la expresa voluntad de los convencionales constituyentes de Santa $\mathrm{Fe}$ de constituir la "Nación Argentina". Con ello puede entenderse los sucesos posteriores vinculados a las formas de colonización adoptadas.

Se marca este punto, porque Sarmiento y otros jurisconsultos mantuvieron la idea que la Constitución Argentina era "un plagio" de la de EEUU. A continuación se señalan las diferencias relevantes, siguiendo a Roberto Núñez (2016):

"Existe una corriente de opinión que considera a la Constitución de 1853 como una especie de transcripción de casi todas las disposiciones de la de los Estados Unidos... Lo siguieron (a Sarmiento) muchos autores y tratadistas, algunos de reconocido talento pero de insufrible miopía, que llegaron a pretender que todas nuestras instituciones resultaban calcos de las norteamericanas y, de tal manera, la jurisprudencia de la Corte de los EE.UU. resultaba libro poco menos que sagrado. Afortunadamente creemos que se ha abierto un ancho camino en el sentido inverso y que buscamos afanosamente nuestras instituciones basadas en las realidades de un país que se esfuerza por obtener su cultura nacional".

A pesar de que en el informe de la Comisión de Negocios Constitucionales se expresa que los federales del Norte son dignos de emulación por su rápido engrandecimiento y su libertad civil y política, y aún cuando Gutiérrez y Gorostiaga afirmaron en el recinto del Congreso que el modelo de la Constitución proyectada era la vigente en EE.UU., resulta oportuna puntualizar que, si de ésta se tomaron 60 artículos, hay otras disposiciones de gran importancia extraídas de antecedentes vernáculos o disímiles a los norteamericanos. Tal es el caso de los arts. 2, 4, 14, 19, 23, 29, 34 y 35, algunos incisos del art. 67, y otros 40 arts. "que reconocen otras fuentes distintas de la Constitución norteamericana".

En las constituciones puede señalarse la existencia de una parte dogmática y otra orgánica. La primera se refiere a las características del Estado y a los derechos de sus habitantes; la otra, al aspecto estrictamente institucional y administrativo. Los preámbulos, que preceden a esas partes, son enunciados de los objetivos perseguidos y fundamentación de los mismos. Y es claro que, por haber sido la Constitución estadounidense la primera republicana, la mayoría de las repúblicas adoptaron el mismo esquema formal, entre ellas la Constitución de 1853.

Los preámbulos de las Constituciones de 1787 y 1853, en tanto sustentan las motivaciones históricas de una y otra, acusan marcadas diferencias de fondo con 
el protocolo (fuente de la autoridad), el texto (enunciado de objetivos) y el escatocolo (fórmula de cierre).

1. Los constituyentes de Filadelfia se declaraban depositarios de la soberanía: "Nos, el pueblo de los Estados Unidos"; los de Santa Fe, representantes del soberano: "Nos, los representantes del pueblo de la Nación Argentina reunidos en Congreso General Constituyente por voluntad y elección de las provincias que la componen".

2. Además, estos últimos dejaban expresa constancia del "cumplimiento de pactos preexistentes", propios de la historia constitucional argentina.

3. Aquéllos, en el texto, se proponían "hacer más perfecta la unión” (preexistente); éstos, por mandato de los pactos, “constituir la unión nacional”, que llevaba más de 40 años postergada.

4. Si en Filadelfia los constituyentes quisieron "asegurar los beneficios de la libertad para nosotros y para nuestros descendientes"-cuidándose bien de establecer extensiones que posibilitaran la indiscriminada igualdad-, en Santa $\mathrm{Fe}$, un poco por afán europeizante y otro por tradición histórica, tales beneficios extendidos, no a los "descendientes", sino a "la posteridad" y además "a todos los hombres del mundo que quieran habitar el suelo argentino".

5. Los constituyentes de Santa Fe, por irrevocable tradición histórica, invocaron previamente "la protección de Dios, fuente de toda razón y justicia”, para luego decidir la constitución de un ente político categóricamente denominado y definido: “la Nación Argentina”.

La postura de Alberdi refutando la opinión de Sarmiento, sostiene la originalidad no sólo de la Constitución Argentina de 1853, sino también de su proceso constitutivo previo.

"Todo es diferente entre las dos constituciones argentina y norte-americana respecto a la organización del gobierno, por más que la forma federal, que les es común, las asemeje al ojo del observador inatento y superficial"xlviii.

Respecto de la concepción de la colonización hay que marcar algunas ideas que influyeron en Sarmiento, a pesar de sus posteriores críticas a la Constitución estadounidense. La estructura agraria que pretendía replicar de pequeños burgeses, "democracia agraria”, como mencionó Terán, chocaba en principio contra el 
poder de la clase terrateniente argentina. Que se asoció a su empresa colonizadora para exterminar a los pueblos indígenas de las zonas rurales productivas.

Por otra parte, esa estructura inspirada en los pobladores calvinistas en EEUU, implicaba el trabajo de la familia rural, que quería lograrse con la inmigración. En cuanto a los cultivos extensivos como el tabaco en Virginia, los pobladores del Sur de EEUU tenían más beneficios que los del Norte, dado que esas tierrasiguiendo a Nuñez- habían sido otorgado a familiares y amigos del Rey de Inglaterra, que posteriormente decidió que la mano de obra a ocupar serían esclavos africanos, no indígenas por su carácter nómade y sin cultura civilizatoria. La presidencia de Sarmiento inicio la campaña militar sobre el Chaco Gualamba, por ello se aportaron estos argumentos para entender la concepción que guiaba la acción política y militar. 


\section{Las tres Constituciones del Chaco: 1951, 1957 y 1994}

La provincia del Chaco tuvo desde su provincialización tres Constituciones: La primera, sancionada en 1951; la segunda, en 1957 y la Constitución Reforma 1957-1994. "Reforma" alude a que la Cámara de Diputados de la Provincia, habilitó la discusión de un corpus de artículos y no todo el corpus constitucional. Contexto y modelización discursiva fueron solapas del proceso de constitución de Régimen de Verdad: la primera (1951) dio cuerpo constitucional a la Provincia Presidente Perón; la segunda, abolía la primera (1957) y daba cuerpo constitucional a la Provincia del Chaco; la tercera no consideró la Constitución abolida de 1951 y la reforma operó sobre algunos artículos de la Constitución de 1957.

Los centrales fueron: Régimen de tierra pública, privatización o no de las empresas estatales de servicios públicos, incorporación de derechos indígenas con estipulación de tierras destinadas a las comunidades (muy enlazada con la discusión sobre el régimen de tierra pública, que otorga potestad del Estado para entregar tierras fiscales, decidir expropiaciones o realizar donaciones con fines específicos)

Se encontró que las relaciones entre propiedad y poder se realizó por regulación, vía del Derecho constitucional, como mediación organizadora del discurso social. Para la discusión de los Derechos Indígenas y la entrega de tierras, se trazaron alianzas y apoyos con organizaciones indígenas, sociales y de la Iglesia Católica. El objetivo era elevar un petitorio unificado donde el reclamo sobre la propiedad de las tierras ingresara al texto constitucional, especificando la cantidad de tierras a transferir a las comunidades indígenas, lo cual no fue logrado.

\section{Oratoria deliberativa}

La retórica y específicamente la oratoria deliberativa, es un género para la toma de decisiones que afectan los recursos de la polis, siguiendo a Aristóteles.

No se trata de cualquier tipo de reunión, sino para tratar temas específicos: propiedad y recursos; la guerra y la paz; impuestos. 
La oratoria deliberativa no legisla sobre el presente sino sobre el futuro. Esta característica la diferencia de la oratoria epidíctica (demostrativa y vale para la discusión con temarios amplios) que busca apoyos y rechazos a las posturas de los contrincantes discursivos y por tanto su tiempo es presente. No es oratoria judicial, que tiene procedimientos de prueba e interviene sobre los hechos pasados, para comprobar o no reclamos, daños, disputas, etc.

La oratoria deliberativa es la forma discursiva para organizar, dar sentido al futuro de la polis y después en cuerpos organizados, con reglamentos del Estado Moderno, a la democracia deliberativa.

Exige roles: los representantes; los ciudadanos, que presencian el debate y un espacio determinado, que pone distancia entre los representantes y los ciudadanos, que son situados en un espacio físico que se denomina barra. Intervienen con voces de apoyo y rechazo, aplausos, pero no en el debate.

Similiar a la organización de la arquitectura de cualquiera de las Cámaras de Representantes de nuestro país.

En estos recintos, preparados para tal fin, se producen registros que son los diarios de sesiones, donde se transcriben todas las expresiones de los legisladores.

Salvo las que se generan en los cuartos intermedios- de negociación política- que no son registrados en las versiones taquigráficas. Son los espacios entre legisladores de consenso o ruptura.

Hay reglas de interacción entre legisladores mediante un Reglamento interno, previamente consensuado: los legisladores no dialogan entre sí, se dirigen al Presidente del cuerpo colegiado; el presidente si quiere argumentar, baja del estrado y delega la presidencia. El presidente modera el debate, organiza la discusión y somete a votación las posiciones, entre otros atributos.

Las Convenciones Constituyentes, caracterizadas y con los atributos de poder creador (Habermas: 2008), fueron en este estudio, siguiendo a Focault, el espacio de creación de los hitos fundacionales de un pueblo, Estado- Nación, que construye hacia el futuro, la historia monumental en los géneros de hitos y epopeya. 


\section{Comparación entre las dos Constituciones fundantes}

El debate parlamentario del Chaco fue una escena más del debate nacional sobre dos visiones contrapuestas de Nación, la expresada en 1853 y la refundante de 1949.

"Dis-cursus es, originalmente, la acción de correr aquí y allá, son idas y venidas, "andanzas, "intrigas" (Barthes:)

El discurso sobre la Nación que cada Constitución fundó y nombró.

Hay una característica que marca la diferencia en términos discursivos, la Constitución de 1949 (y de 1951) operó más como una proclama de derechos de los trabajadores que con la matriz jurídica y el andamiaje de densidad en los artículos y los fundamentos que la de 1957 (que retoma el texto casi completo de 1853).

De qué clase o facción tuvo el poder en cada momento de refundar la Nación.

Por ello también la asociación con el concepto de Revolución con el que se llamaron ambos movimientos: "Revolución Peronista"; "Revolución Libertadora".

Era vocación de cada facción refundar, resignificar el orden y constituir por tanto un régimen de verdad.

\section{Falacias}

En la discusión de las Constituciones fundantes se reiteró una cierto tipo de falacias propias de la oratoria deliberativa.

“A todas las formas de argumentación que encierran errores o persiguen fines espurios, los llamamos falacias. El término procede del latín fallatia, que significa engaño, y lo empleamos como sinónimo de sofisma, palabra que acuñaron los griegos para designar el argumento engañoso. Ya se ve que la terminología es imprecisa porque mezcla errores de razonamiento (por ejemplo una generalización precipitada), con maniobras extra-argumentales (por ejemplo un ataque personal), e incluye también los falsos argumentos que se emplean con la intención de engañar o desviar la atención (por ejemplo la falacia ad ignorantiam, la pista falsa o las apelaciones emocionales). Todos tienen una cosa en común: adoptan la apariencia de un argumento e inducen a aceptar una proposición que no está 
debidamente justificada. Unas veces nos engaña nuestro juicio y otras las mañas de nuestro interlocutor ${ }^{x l i x}$

\begin{tabular}{|c|c|c|}
\hline Falacias & 1951 & 1957 \\
\hline ATAQUE PERSONAL & La Constitución de & La Constitución de \\
\hline Grupo de falacias que desvían & 1951, en el Chaco, no & 1957 establece un \\
\hline la atención del asunto que se & desarrolla ningún & artículo para las \\
\hline discute hacia la persona & capítulo especial, ni & poblaciones indígenas. \\
\hline del adversario o sus & plantea debate sobre los & Descalificó la falta de \\
\hline circunstancias. & pueblos indígenas. & argumentación jurídica \\
\hline Cuando se trata, como es & Define una sola clase de & y el origen de los \\
\hline habitual, de sostener & hombre: "el trabajador", & convencionales, la \\
\hline afirmaciones indemostrables & y bajo esa & "cosa pública" como \\
\hline o & denominación establece & potestad de clase: \\
\hline decisiones basadas en & los derechos sociales. & incipiente burguesía y \\
\hline conjeturas, cobra & Crítica a la oligarquía y & la oligarquía nacional. \\
\hline extraordinario valor & a los monopolios, vía & Es el mismo \\
\hline persuasivo el prestigio de la & descalificación. & argumento que se \\
\hline persona que da el consejo o & No hay distingos de un & blandió en 1949 en la \\
\hline hace la propuesta. En los & "antes", de la historia & Nación, y en 1951 en \\
\hline casos dudosos & de la conquista, aunque & el Chaco, era de una \\
\hline (es decir, en la mayoría), & asume, da por sentado & clase: la trabajadora. \\
\hline concedemos la razón con más & que los chaqueños están & De allí que en ambas \\
\hline facilidad a aquellos en & representados por el & discusiones, se marcan \\
\hline quienes confiamos, sean & "blanco del algodón y & los vicios de "origen". \\
\hline médicos, asesores fiscales, $\mathrm{o}$ & la dureza del & \\
\hline políticos. Más del $80 \%$ de la & quebracho". & \\
\hline persuasión nace de la & El "crisol de razas" del & \\
\hline confianza que inspire el & que habla el historiador & \\
\hline consejero. & Guido Miranda no fue & \\
\hline Un razonamiento que procede & discutido en la & \\
\hline de gente sin fama y el mismo, & Convención de 1951, & \\
\hline pero que viene de gente & sino aceptado. & \\
\hline
\end{tabular}




\begin{tabular}{|c|c|c|}
\hline $\begin{array}{l}\text { famosa, no tienen igual } \\
\text { fuerza. } \\
\text { Ahí radica la fortaleza de un } \\
\text { político, pero también su } \\
\text { punto vulnerable. La } \\
\text { difamación es tan frecuente } \\
\text { en la vida pública porque los } \\
\text { políticos comprenden } \\
\text { instintivamente la necesidad } \\
\text { de arruinar el crédito moral de } \\
\text { sus adversarios. En } \\
\text { un dirigente sin prestigio los } \\
\text { argumentos parecerán } \\
\text { argucias, las emociones farsa, } \\
\text { y la sinceridad, hipocresía. De } \\
\text { aquí procede un componente } \\
\text { inevitable de la } \\
\text { acción política: la batalla por } \\
\text { la imagen propia y el } \\
\text { desprestigio de la ajena que, a } \\
\text { veces, convierte las } \\
\text { locuciones públicas en } \\
\text { simples variaciones de un } \\
\text { único mensaje sustancial: yo } \\
\text { propongo lo más justo y mi } \\
\text { oponente es un felón. } \\
\text { Hay dos argumentos falaces o } \\
\text { adversario: la Falacia ad } \\
\text { homeargumentos que atacan } \\
\text { anente ala del } \\
\text { antos porque }\end{array}$ & $\begin{array}{l}\text { El momento histórico } \\
\text { ameritaba el apuro de } \\
\text { las reformas para el } \\
\text { Partido Peronista, de } \\
\text { allí ese } \\
\text { constitucionalismo } \\
\text { social, de básicos } \\
\text { principios, a través de } \\
\text { convencionales } \\
\text { designados por el Líder, } \\
\text { de marcado sesgo } \\
\text { corporativo, que como } \\
\text { plantea la Dra. Ana } \\
\text { Rosa de Foulkes, era } \\
\text { una estrategia para } \\
\text { compensar el poder de } \\
\text { las demás } \\
\text { corporaciones } \\
\text { existentes en el país y } \\
\text { que operaban en la } \\
\text { provincia. }\end{array}$ & $\begin{array}{l}\text { "Revolución } \\
\text { Libertadora" }\end{array}$ \\
\hline
\end{tabular}




\begin{tabular}{|l|l|l|}
\hline ninguno refuta las & \\
afirmaciones del contrincante. & & \\
El primero se limita a & & \\
descalificarlo como persona y & & \\
el segundo forja un oponente & & \\
imaginario fácil de tumbar. & & \\
Son también, como se ve, & & \\
carga de la pruebal. & & \\
\end{tabular}

Se observó el carácter de la palabra fingida, con relación a la definición de Barthes. Los argumentos exhibidos en los debates de las Constituciones estaban orientados a un propósito pragmático de persuasión. Lo cual prueba que las definiciones eran previas a las Convenciones y los argumentos hicieron eje en la descalificación de las facciones en pugna.

Refuta también el argumento de "andamiaje jurídico, no político" defendido por los convencionales de 1957. 


\section{3) Derechos indígenas como modelización discursiva en el discurso parlamentario}

\section{-Genealogía de la construcción de "ellos y nosotros" \\ Civilización y barbarie}

Para entender el proceso de las Constituciones en el Chaco, se recurrió a la genealogía en el pensamiento dominante en la fundación de la Nación Argentina.

"Sarmiento y Alberdi son dos figuras centrales de la llamada "Generación del 37”, un grupo de jóvenes intelectuales que, nucleados en el Salón Literario de Marcos Sastre- con la notable excepción de Sarmiento-, reconocen la necesidad de pensar, estudiar, analizar la particular realidad social argentina. ¿Cuáles son los obstáculos para la institucionalización de un orden político liberal? ¿Cómo hacer, ante el caos de las guerras civiles, para efectivamente instalar un orden que inscriba a la Argentina en el camino del progreso político y económico? Éstas son, en síntesis, las preguntas que atizarán la reflexión de estos intelectuales hasta el final de sus días o, lo que es lo mismo hasta casi el final del siglo XIX” (Oscar Terán: 2009)

Terán consideró a la Generación del 37, como el primer movimiento intelectual que enfatizó la necesidad de construir una identidad nacional. "Sus integrantes más reconocidos son Esteban Echeverría (inspirador del agrupamiento), Domingo Faustino Sarmiento, Juan Bautista Alberdi, Juan María Gutiérrez, Vicente Fidel López, José Mármol y Feliz Frías” (TERÁN: 2009).

"Luego de un período durante el cual alientan ciertas expectativas positivas hacia el régimen de Juan Manuel de Rosas, los miembros de esta generación ingresaran en una activa política de oposición que los llevará al exilio (Bolivia, Brasil y especialmente Chile y Montevideo), de donde regresarán luego de la batalla de Caseros de 1852. Al respecto, apelamos a las Memorias del general Paz para encontrar la formulación desde el campo antirrosista de la problemática que en esos años enfrentaba a los bandos políticos en el Río de la Plata:

No sería inoficioso advertir que esa gran fracción de la república que formaba el Partido Federal no combatía solamente por la mera forma de gobierno. Pues 
otros intereses y otros sentimientos se refundian en uno solo para hacerlo triunfar.

Primero: era la lucha de la parte más ilustrada contra la porción más ignorante. Segundo: la gente de campo se oponía a la de las ciudades. Tercero: la plebe se quería sobreponer a la gente principal. Cuarto: las provincias, celosas de la preponderancia de la capital, querían nivelarla. Quinto: las tendencias democráticas se oponían a las miras aristocráticas y aún monárquicas. Todas estas pasiones, todos estos elementos de disolución y anarquía, se agitaban con una terrible violencia, y preparaban el incendio que no tardó en llegar" (TERÁN: 2009)

Terán realiza una aclaración no menor, al destacar que en título del libro de Sarmiento, no plantea una disyuntiva mediante "o" sino una conjunción "y".

Es decir, apela a un paso, no a una dicotomía.

A los fines de no caer en anacronismos y comprender las condiciones de producción del discurso, en las que fue formulado, no en nuestros marcos actuales fue relevante definir los dos conceptos, que constituyen un binomio.

A continuación, se reprodujo la tabla de oposiciones binarias entre términos que se corresponden con la civilización y con la barbarie ${ }^{\text {li. }}$

\begin{tabular}{|l|l|}
\hline Civilización & Barbarie \\
\hline Ciudad & Campaña \\
\hline Europa & América \\
\hline Modernidad & Atraso \\
\hline Movilidad & Inmovilidad \\
\hline Letrado & Iletrado \\
\hline Francia & España/colonia \\
\hline Libertad & Despotismo \\
\hline Sociedad/ Gobierno & Familia/ Caos político \\
\hline Comercio- Agricultura & Ganadería (estancia) pastoril \\
\hline Razón & Instintos pasiones \\
\hline Laboriosidad & Ocio \\
\hline Siglo XIX & Edad Media (siglo XII) \\
\hline Espíritu & Materia \\
\hline
\end{tabular}


Estas ideas se tomaron en cuenta para el caso estudiado, porque fue Sarmiento como Presidente de la Nación quien dispuso la creación del Territorio Nacional del Chaco.

Este binomio atravesó la Convención Constituyente de 1957, en la discusión parlamentaria y llegó a la Convención Reformadora, bajo los aires neoliberales de 1994.

Resultó significativo entender que Sarmiento fue un hombre de la modernidad moderno, "ya que no apela a explicaciones de corte mágico o religioso, sino que busca causas concretas, materiales, positivas. A partir de ellas apela a una de las primeras concepciones que trataron de dotar de este tipo de racionalidad a las formaciones sociales: la teoría del medio". (TERÁN: 2009)

Formulada en la tradición grecolatina consideró que las personas que viven en las llanuras son distintas de las que viven en las montañas, y así las que viven en el mar. Montesquieu y su espíritu de las leyes fue un referente para Sarmiento. "La democracia se corresponde con un territorio montañoso y en las planicies, como la pampa argentina, impera el nepotismo".

Siguiendo ese razonamiento, en el Territorio Nacional del Chaco, monte y poblaciones indígenas, fueron necesarias adaptar a la epopeya civilizatoria.

La idea de Sarmiento de crear - como Presidente- un programa nacional inspirado en la "democracia agraria" que vio en los EEUU, "fracasa debido al régimen de apropiación latifundista de la tierra. Ante esa decepción, el viejo Sarmiento acuñará el célebre insulto dirigido a la clase poseedora: “Aristocracia con olor a bosta" (TERÁN: 2009)

Sin embargo, estas ideas de Sarmiento, tuvieron importante predicamento en el Chaco, primero porque los territorios habían sido ganados a los indígenas y no existían pertenencias aristocráticas propias de la Pampa húmeda. Llegaron contingentes inmigratorios provenientes de Europa con el sueño de crear las granjas, trabajar la agricultura y la ganadería.

La idea de "laboriosidad" atravesó la sociedad emergente del Territorio Nacional del Chaco.

Así también, el pensamiento de "democracia agraria" se expresó en la Constitución de 1957 a través de la organización en cooperativas y el Régimen de Tierra pública para evitar los latifundios y tierras improductivas. 


\section{Contexto: Otros hitos fundacionales antes de la Reforma de 1994}

Cada marca discursiva, cada victoria o derrota, según la facción que se trate construye un devenir en la historia de los pueblos.

Tras la sanción de la Constitución de 1957, el Chaco vivió el desarrollismo de Frondizi, con el gobernador Ducca.

Deolindo Felipe Bittel, vicegobernador del primer gobierno de 1953, desobedeció la orden de Perón de votar en blanco y presentó su candidatura y ganó la gobernación en 1962.

De este tipo de peronistas fue del que habló el documento de 1957. Los peronistas "moderados" y formados. Deolindo Felipe Bittel era escribano, nacido en la Provincia de Santa Fe y llegó al Chaco como joven profesional.

A partir de la dictadura de Onganía y hasta el retorno del General Perón, el Chaco vivió la "tradición" del crisol de razas, manteniendo los rituales de la agricultura y ganadería en fiestas y festivales.

En 1973, volvió a ganar el peronismo en las urnas y asumió la gobernación nuevamente Deolindo Felipe Bittel, hasta el golpe de 1976.

\footnotetext{
Gobernadores del Chaco

1-Julio de Vedia: Designado el 31 de enero de 1872, termino su mandato el 31 de enero de 1875, Hasta el 20 de febrero de 1875, desempeño interinamente la gobernación el secretario, Belisario Gache.

2-Napoleón Uriburu: Su mandato comenzó el 20 de febrero de 1875 y caducó exactamente- tres años después. ( Se cree que su sucesor fue Pantaleón Gómez, pero no se conocen datos exactos.)

3-Lucio V. Mansilla: Su mandato abarca desde el 28 de octubre de 1878 hasta el 5 de noviembre de 1880 .

4-Francisco B. Bosch: Designado el 12 de noviembre de 1880, gobernó en el Chaco hasta el 3 de octubre de 1883.

5-Ignacio Fotheringham: Designado el 3 octubre de 1883, pasó a ocupar el cargo de Gobernador de Formosa al dividirse el territorio Nacional del Chaco el 25 de noviembre de 1884 .

6-Manuel Obligado: Desde el 25 de noviembre de 1884 hasta principios de 1887.
} 
7-Antonio Donovan: Desde el 15 de abril de 1887 hasta el 18 de agosto de 1893.

8-Enrique Luzuriaga: Designado el 3 de agosto de 1893, desempeñó su cargo durante cuatro períodos consecutivos, es decir, hasta 1905.

9-Martín Goitía: Del 28 de enero hasta, el 6 de junio de 1905.

10-Gregorio López: desde el 6 de junio de 1905 hasta el 20 de junio de 1911.

11-Anacarsis Lanus: Desde el 20 de junio de 1911 hasta el 16 de junio de 1914.

12-Alejandro Gancedo: Desde el 16 de junio de 1914 hasta el 28 de abril de 1917.

13-Enrique Cáceres: Desde el 28 de abril de 1917 hasta el 1 de octubre de 1920.

14-Oreste Arbo y Blanco: Desde el 1 de octubre de 1920 hasta el 26 de junio de 1923.

15-Fernando E. Centeno: Desde el 26 de junio de 1923 hasta el 23 de junio de 1926.

16-Juan Carlos Cepeda: Desde el 26 de junio de 1926 hasta el 4 de mayo de 1929. 17-Ricardo Andreu: Desde el 4 d mayo de 1929 hasta la revolución del 6 de septiembre de 1930.

18-Armando Meabe: Desde septiembre de 1930 hasta su renuncia antes de cumplir el año de gobierno.

19-Juan S. Mac Lean: Desde el 16 de junio de 1931 hasta el 21 de junio de 1932. 20-Juan Vrillaud: Desde el 21 de junio de 1932 hasta el 23 de septiembre de 1933. 21-José C. Castells: Desde el 23 de septiembre de 1933 hasta el 10 de agosto de 1938, cumpliendo dos períodos de gobierno.

22-Gustavo R. Lagerheim: Desde el 10 de agosto de 1938 hasta el 11 de septiembre de 1941.

23-Florencio M. Solari: Desde el 11 de septiembre de 1941 hasta el 4 de junio de 1943.

24-Alberto M. Castro: Desde el 25 de junio de 1943 hasta el 25 de agosto de 1944, fecha en que renunció.

25-Martín Carlos Martinez: Desde el 1 de septiembre de 1944 hasta el 25 de junio de 1946, renunciando en esa oportunidad.

26Antenor Farías: Desde el 19 de octubre de 1946 hasta el 19 de octubre de 1949.

27-Nicolás J. Russo: Desde noviembre de 1949 hasta 1951, actuando como interventor al producirse la provincialización del chaco.

28-Juan Carlos Brusco: Desde 1951 hasta el 4 de junio de 1953. 
29-Felipe Gallardo: Desde el 4 de junio de 1953 hasta el 16 de septiembre de 1955.

30-Rafael Claudio Ortega: Desde el 22 de septiembre de 1955 hasta el 25 de septiembre de 1955.

31-Oscar Rodrigo Uncal: Desde el 25 de septiembre de 1955 hasta el 1 de octubre de 1955.

32-Angel Peluffo: Desde el 3 de octubre de 1955 hasta el 8 de octubre de 1955.

33-Miguel Angel Mascaro: Desde el 9 de octubre de 1955 hasta el 28 de diciembre de 1955.

34-Pedro Avalía: Desde el 4 de enero de 1956 al 1 de mayo de 1958.

35-Anselmo Zoilo Duca: Desde el 1 de mayo de 1958 hasta el 19 de marzo de 1962.

36-Manrique Miguel Mom: Desde el 19 hasta el 21 de marzo de 1962.

37-Víctor Hugo Fleytas: Desde el 21 de marzo de 1962 hasta el 25 de abril de 1962.

38-Manrique Miguel Mom: Desde el 25 de abril hasta el 30 de junio de 1962.

39-Marcelino Castelan: Desde el 30 de junio de 1962 hasta el 5 de octubre de 1963.

40-Osvaldo Núñez: Desde el 6 de octubre hasta el 12 de octubre de 1963.

41-Deolindo Felipe Bittel: Desde el 12 de octubre de 1963 hasta el 29 de junio de 1966.

42-Ricardo Pacífico del Corazón de Pompeya Miró: Desde el 29 de junio de 1966 hasta el 4 de agosto de 1966.

43-Rafael Torrado: Desde el 4 de agosto de 1966 hasta el 16 enero de 1967.

44-Miguel Ángel Basail: Desde el 23 de enero de 1967 hasta el 21 de mayo de 1971.

45-Cnel. Roberto Oscar Mazza: Desde el 24 de mayo de 1971 hasta el 25 de mayo de 1973. Como Interventor.

46-Escr. Deolindo Felipe Bittel: Desde el 25 de mayo de 1973 hasta el 24 de marzo de 1976.

47-Cnel. Oscar Zucconi: Desde el 24 de marzo de 1976 al 23 de abril de 1976.

48-Cnel. R.E. Antonio Serrano: Desde el 23 de abril de 1976 hasta el 29 de marzo de 1981. 
49-Cnel. José David Ruiz Palacios: Desde el 29 de marzo de 1991 hasta el 11 de diciembre de 1983.

Fuente: Legislatura del Chaco (2016)

http://legislatura.chaco.gov.ar/Biblioteca/Documentos/gobernadores.htm

\section{Dictadura: “Chaco Puede” (1976-1979)}

"El consenso social en la dictadura solo puede explicarse en alianza con uno de los sujetos locales de más tradición institucional chaqueña: el cooperativismo" (ROZÉ: 2007).

"En términos estructurales, se asistía a la internacionalización de la economía chaqueña "la acción más importante destinada a modificar la estructura productiva fue encarada con el objetivo de transformar el proceso de comercialización del algodón, de la ganadería regional y de la producción de granos" (ROZÉ: 2007)

En una entrevista realizada al ministro de Economía Benedit, por el diario La Nación, el 23 de marzo de 1978, el funcionario afirmó que "Sobre 10 millones de hectáreas del Chaco, seis millones eran fiscales, pobladas por intrusos con un comportamiento típico de quien no hace uso efectivo de la propiedad. El propietario tiene propensión a invertir, mientras el intruso tiende solamente a consumir. El cambio de tenencia de la tierra es el cambio estructural e ideológico más importante que gestamos y esperamos consolidar en el Chaco".

"Chaco Puede" se evidenció en una serie de acciones, que apelaban a las gestas históricas y sociopolíticas de la provincia:

a) La conquista: la campaña del Oeste chaqueño, el avance hacia El Impenetrable, la fundación de Fuerte Esperanza

b) La colonización: la reorganización del territorio y el cambio de la propiedad de la tierra, vía diversos instrumentos jurídicos y la política de tierras.

c) El progreso: a través de la tecnificación y del aumento de las áreas de explotación y la formación de cuadros "técnicos".

El gobierno militar en 1978, en conmemoración del centenario del desembarco de inmigrantes italianos, realizó un festejo monumental, reproduciendo el ritual de 
llegada y bienvenida del Chaco, editando un libro con el relato de la colonización de El Impenetrable y con los "logros” del Proceso de Reorganización Nacional.

\section{Alternancia entre peronismo y radicalismo: 1983- 1994}

La provincia del Chaco tuvo una marcada polarización entre el Partido Justicialista y la Unión Cívica Radical, aún cuando se han presentado con denominaciones de distintos Frentes políticos.

Florencio Tenev, gobernador peronista, desde el 11 de diciembre de 1983 hasta el 11 de diciembre de 1987. Convivió con el gobierno de Raúl Alfonsín.

Fue continuado por el peronista Danilo Luis Baroni, quien gobernó desde el 11 de diciembre de 1987 hasta el 11 de diciembre de 1991.

La reaparición del último gobernador de facto, el coronel José David Ruiz Palacios, rompió con esa alternancia, al presentar una tercera fuerza.

Ruiz Palacios convocaba a los "gringos que hicieron el Chaco", apoyado en la buena imagen de su gestión, dado que ya había finalizado el proceso genocida en su aspecto más sangriento, en 1983. Se paró sobre otro hito: las inundaciones. E inició el primer Plan de Defensa.

Que remitió en mucho, al los planes de Defensa contra los "indios" primero, contra la "subversión" después.

El desgaste y las malas gestiones de los partidos tradicionales facilitaron su crecimiento.

Retomó los ideales del Chaco de 1957, fue intendente de Resistencia, y no pudo ser candidato a Gobernador, por la exigencia de años de residencia en la Provincia, vía un recurso presentado por un referente de la Democracia Cristiana, José María Romero, partido aliado del FREJULI.

No obstante, obtuvo la gobernación para su partido denominado "Acción Chaqueña".

Fue Rolando Tauguinas, quien gobernó entre el 11 de diciembre de 1991 hasta el 11 de diciembre de 1996. Quebró la alianza con el Coronel Ruiz Palacios, su gobierno tuvo marcadas deficiencias en la administración, pero se logró neutralizar al peronismo.

Durante el gobierno de Tauguinas se llama a Convención Reformadora, siguiendo los lineamientos nacionales de 1994. 
En la provincia, el gobierno de Acción Chaqueña adhería al gobierno nacional encabezado por Carlos Saúl Menem. Compartían principios sobre el capitalismo de mercado, y estaba la postura a favor de la privatización de los servicios públicos, el traspaso de la Caja Previsional Chaqueña y el endeudamiento del Estado Provincial.

El peronismo, fuera del gobierno provincial, se debatió en sus contradicciones entre grupos leales al menemismo y otros que comenzaban a perfilar la formación que posteriormente acompañó la postulación de José Octavio Bordón.

Por ello, primero en la Legislatura chaqueña y después en la Convención, hubo games de distinta índole, acuerdos entre radicales y peronistas en contra del traspaso de la Caja Previsional a la Nación, hecho que se logró mediante una ley que mantuvo el carácter provincial de esos recursos.

Un plesbiscito convocado previamente a la Convención Constituyente, para lograr apoyo popular en contra de la privatización de las empresas del Estado Provincial, que se plasmó en una dura discusión en la Convención, saldada con la prohibición de la venta de las mismas (aunque operó en posteriores gobiernos vía tercerización de servicios).

El otro punto fue el ballotage, contenido también en el Pacto de Olivos. Aquí los peronistas chaqueños, se equivocaron de enemigo, y lo establecieron pensando como oponente al Coronel Ruiz Palacios, y no a un adversario del radicalismo.

La tercera fuerza ya estaba debilitada en ese entonces y el ballotage terminó siendo la pesadilla del peronismo chaqueño. Puesto que siempre le costó poner distancia entre los adversarios salvo en elecciones muy cómodas. 


\section{LOS PACTOS PREEXISTENTES A LA CONSTITUCIÓN DE 1994}

En 1994, se consolidó la reforma neoliberal en el texto constitucional. El Pacto de Olivos fue el acuerdo alcanzado para su materialización. Así lo relató Alicia de Dromi, esposa del responsable de los textos de la reforma administrativa, Roberto Dromi, ministro del Presidente Carlos Menem:

"La necesidad de entablar un diálogo para acercar las distintas posiciones impulsó a las dos fuerzas políticas mayoritarias a dar un paso histórico hacia la profundización democrática del país. Como expresión del consenso, el 14 de noviembre de 1993 el presidente Carlos Menem y el ex presidente Raúl Alfonsín, suscribieron el Pacto de Olivos.

El pacto legitima la expresión de la voluntad popular no para la conformación del Estado, como lo expresaban las teorías contractualistas, sino para la modernización institucional de un nuevo Estado.

El objetivo se consolidó el 13 de diciembre de 1993, cuando Menem y Alfonsín suscribieron el Pacto Preconstitucional o de la Rosada, complementario del Pacto de Olivos"

(...) La Constitución argentina no existiría si antes no hubiera habido un cierre político de "Provincias y Caudillos", como, por ejemplo, en el Tratado del Pilar (1820), en el Tratado del Cuadrilátero (1822), en el Pacto Federal (1831); en el Acuerdo de San Nicolás (1852) y en el Pacto de San José de Flores (1859). La “paz" para el nuevo orden se logra sobre la base de pactos, tratados y acuerdos.

El acuerdo tradujo la convicción de que la reforma constitucional debía nacer de un gran pacto político, a través de la participación y consenso de todos los sectores de la sociedad.

Así nació el "Pacto de Olivos", marco político- programático para el proyecto de reforma constitucional.

El Pacto logrado legitimó la expresión de la "voluntad popular", no para la conformación del Estado, como lo expresaban las teorías contracturalistas, sino para la modernización institucional del nuevo Estado ${ }^{\text {lii,". }}$

Con esa concepción el Partido Justicialista, emitió un documento sobre los puntos básicos de reforma constitucional, necesarios para garantizar la Reforma del Estado, o su traducción en privatizaciones y venta del patrimonio nacional. 
A continuación:

DOCUMENTO JUSTICIALISTA

“c) Asegurar la reforma del Estado

Está instalada la decisión política de la reforma del Estado, Leyes de la Nación disponen la descentralización, la privatización, la concesión, la desregulación del sector productivo. El gobierno, consecuentemente, ha producido esas modificaciones en la estructura estatal.

Si no reformamos la Constitución, la reforma del Estado será un mero logro transitorio, supeditado a los vaivenes, a las marchas y contramarchas de los gobiernos de turno. No había reforma del Estado en el sentido y en la dirección propuestos si la Constitución no la garantiza y ella sólo se garantizará cuando se reforme $e^{\text {liii }, ~}$

El objetivo de la Reforma de 1994, como lo expone San Martino de Dromi fue descentralización, privatización, concesión y desregulación del sector productivo

El documento Justicialista conformó el núcleo de Coincidencias Básicas de la reforma, en acuerdo con la UCR. Aprobada por la Convención Partidaria.

Por lo tanto, se trató de una alianza de los partidos mayoritarios para consumar la denominada reforma del Estado, cuyo carácter no pueda ser modificado por ley. Sino que ingresé como norma constitucional.

En tanto, el drama estaba montado sobre: la duración del mandato presidencial, el ballotage, la elección de jueces.

¿Qué pasó en el Chaco con las privatizaciones?

Los convencionales llegaron a la Convención con una limitación política: la prohibición de habilitar la privatización de las empresas del Estado provincial, vía plebiscito no vinculante, votado en las mismas elecciones a Constituyentes.

Fue un tema de consideración pública por parte de la prensa y tuvo una participación activa de los sindicatos de esas empresas, los trabajadores organizados. 
La participación en el plebiscito no fue obligatoria, por lo cual se discutió su viabilidad jurídica, pero los factores de presión sindical, pudieron torcer la decisión de la privatización. En este caso, vía constitucional, se mantuvo la redacción del artículo 49 de la Constitución de 1957: la prohibición expresa de privatización o concesión de servicios públicos provinciales.

\section{Las reglas de construcción discursiva}

El debate constitucional de 1994 tuvo reglas expresadas en un estudio sobre Derecho Constitucional, acerca de la Constitución del Chaco 1957-1994, redactado por tres convencionales constituyentes de 1994(Abraham y otros: 2011).

Este texto describió y analizó las "definiciones de los aspectos relevantes de la situación comunicativa por los propios intervinientes", siguiendo a Van Dikj.

$\mathrm{Su}$ valor testimonial, ayudó a la reconstrucción de las reglas de construcción del discurso, su factibilidad y validez, consensuadas para la Reforma de 1994, en el Chaco.

Permitió reconstruir posiciones retóricas respecto de la Constitución, los propósitos pragmáticos y las reglas discursivas de los actores legitimados:

1) "El texto constitucional es un documento destinado a regular la vida de la comunidad en sus aspectos fundamentales y por un tiempo prolongado. Al decir de Pedro Néstor Sagués, tiene vocación de "difusión y futuridad" es por ello que su vocabulario debe ser claro y sencillo, de fácil comprensión por el pueblo".

2) "En cuanto a la arquitectura constitucional tradicionalmente se reconocen tres partes: el "preámbulo", el “cuerpo" dividido en una parte dogmática o de declaraciones derechos y garantías y otra orgánica o de estructuración del poder del Estado, y los apéndices (cláusulas complementarias y/o transitorias fraccionándose la misma en secciones, títulos, artículos e incisos”.

3) Algunas reglas de técnica constitucional que proponen observe el Legislador Constituyente: “Adecuación a la realidad. Que la Constitución refleje lo más fielmente posible la realidad jurídica, política, social y económica del pueblo. Se enrolan en este pensamiento clásico grecorromano, Montesquieu (El Espíritu de las leyes), San Martín (Cartas a O’Higgins), Esteban Echeverría (El Dogma 
Socialista), Rivadavia, Mitre y Juan B. Alberdi (Bases y Puntos de partida para la organización nacional) entre otros".

4) Poder constituyente: “Coincidiendo con Segundo Linares Quintana podemos definir al "Poder Constituyente", como la facultad soberana del pueblo a darse su ordenamiento jurídico político fundamental originario, por medio de una Constitución y a revisar esta, total o parcialmente cuando sea necesario. (...) La única limitación que tiene es respetar ciertos valores naturales absolutos”

\begin{tabular}{|c|c|c|}
\hline Matriz discursiva & $\begin{array}{l}\text { Propósitos } \\
\text { pragmáticos }\end{array}$ & Reglas discursivas \\
\hline $\begin{array}{l}\text { Modelo retórico: oratoria } \\
\text { deliberativa }\end{array}$ & $\begin{array}{l}\text { Documento destinado } \\
\text { a regular la vida de la } \\
\text { comunidad en sus } \\
\text { aspectos } \\
\text { fundamentales y por } \\
\text { un tiempo prolongado }\end{array}$ & $\begin{array}{l}\text { Arquitectura } \\
\text { constitucional: el } \\
\text { "preámbulo", el } \\
\text { "cuerpo" dividido en } \\
\text { una parte dogmática o } \\
\text { de declaraciones } \\
\text { derechos y garantías y } \\
\text { otra orgánica o de } \\
\text { estructuración del } \\
\text { poder del Estado, y los } \\
\text { apéndices } \\
\text { ( cláusulas } \\
\text { complementarias y/o } \\
\text { transitorias } \\
\text { fraccionándose la } \\
\text { misma en secciones, } \\
\text { títulos, artículos e } \\
\text { incisos". }\end{array}$ \\
\hline $\begin{array}{l}\text { Asunción de la } \\
\text { delegación/representación del } \\
\text { poder Constituyente y } \\
\text { concepción del Pueblo }\end{array}$ & $\begin{array}{l}\text { Poder Constituyente, } \\
\text { como la facultad } \\
\text { soberana del pueblo a } \\
\text { darse su ordenamiento }\end{array}$ & $\begin{array}{l}\text { Legislador } \\
\text { Constituyente: } \\
\text { “Adecuación a la } \\
\text { realidad. Que la }\end{array}$ \\
\hline
\end{tabular}




\begin{tabular}{|l|l|l|}
\hline & $\begin{array}{l}\text { jurídico político } \\
\text { fundamental } \\
\text { originario, por medio } \\
\text { de una Constitución }\end{array}$ & $\begin{array}{l}\text { Constitución refleje lo } \\
\text { más fielmente posible } \\
\text { la realidad jurídica, } \\
\text { política, social y } \\
\text { económica del pueblo". }\end{array}$ \\
\hline Racionalismo & $\begin{array}{l}\text { Respetar ciertos } \\
\text { "validez/ Contrato social naturales } \\
\text { absolutos" }\end{array}$ & $\begin{array}{l}\text { Vocabulario "claro y } \\
\text { sencillo, de fácil } \\
\text { comprensión por el } \\
\text { pueblo" }\end{array}$ \\
\hline
\end{tabular}


Dis-curses sobre los indígenas

Se realizó una comparación a los fines analíticos sobre el artículo 34, referido a los Derechos Indígenas, en la Convención de 1957 y la de la Convención Reformadora 1957-1994

1957.Articulo 34

"Art 34"- La provincia protegerá al aborigen por medio de una

legislación adecuada que conduzca a su integración en la vida nacional y provincial, a su radicación en la tierra, a su elevación económica, a su educación y a crear la conciencia de sus derechos, deberes, dignidad y posibilidades emergentes de su condición de ciudadano. Quedan suprimidos los sistemas de misiones, reducciones u otros que entrañen su diferenciación y aislamiento social"
1994. Artículo 34

“Artículo 34.- La Provincia reconoce la preexistencia de los pueblos indígenas y su identidad étnica y cultural, la personalidad jurídica de sus comunidades y la propiedad comunitaria e inmediata de la tierra que poseen en la actualidad y las otorgadas en reserva, y regulará la entrega de otras aptas y suficientes para el desarrollo humano. Las mismas se entregarán como reparación histórica, en forma gratuita, exenta de todo gravamen. Serán inembargables, imprescriptibles, indivisibles e intransferibles a terceros.

El Estado asegurará: a) La ecuación bilingüe e intercultural; b) La participación en la protección, preservación, conservación y recuperación de sus recursos naturales y de los demás intereses que los afecten, asegurando su desarrollo sustentable; c) Proponder a su 


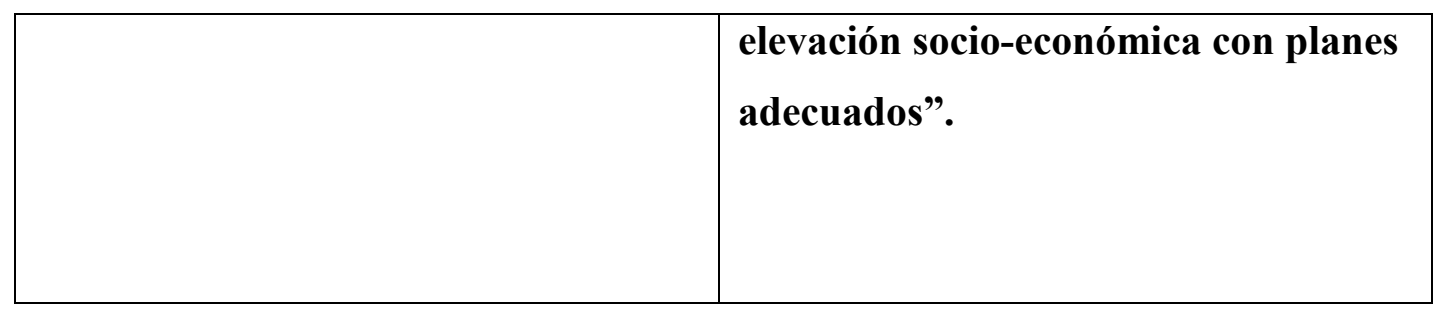

¿Qué cambios introdujo sobre derechos indígenas la Convención de 1957?

Primero, su incorporación en el texto constitucional, puesto que no la tuvo en 1951. Hubo un solo despacho. No obstante, se dirimieron dos posiciones discursivas, en contra, de parte del mismo miembro informante, el convencional Maldonado y otra a favor de la inclusión del artículo 34 por parte del convencional Vargas (miembros informantes) (Fuente: versión taquigráfica 1957)

\begin{tabular}{|c|c|}
\hline En contra del artículo 34 & A favor del artículo 34 \\
\hline $\begin{array}{l}\text { Contraria a la Constitución Nacional } \\
\text { que establece la igualdad de todos los } \\
\text { habitantes ante la ley: }\end{array}$ & $\begin{array}{l}\text { La ley es igual para todos, pero hay un } \\
\text { aspecto que surge de la naturaleza, de } \\
\text { la realidad misma de las personas: el } \\
\text { trabajador, el indio }\end{array}$ \\
\hline $\begin{array}{l}\text { "La inclusión en la Constitución de } \\
\text { normas relativas al indio, al aborigen, } \\
\text { establecen una distinción contraria a } \\
\text { nuestra Constitución y a la Constitución } \\
\text { Nacional. } \\
\text { El artículo anteriormente aprobado } \\
\text { establece..."que todos los habitantes } \\
\text { son iguales ante la ley y que todos } \\
\text { tienen la misma dignidad social". } \\
\text { Y la igualdad ente la ley ha sido } \\
\text { definida por la Corte Suprema Nacional } \\
\text { diciendo que "consiste en que no se } \\
\text { establezcan excepciones o privilegios } \\
\text { que excluyan a unos de los que se }\end{array}$ & $\begin{array}{l}\text { “La extrañeza, asombro y alarma de } \\
\text { que a un sector de la población, de } \\
\text { acuerdo a este artículo del proyecto, se } \\
\text { lo considere en forma distinta a los } \\
\text { demás, no lo veo; no veo que en } \\
\text { ninguna parte este artículo justifique } \\
\text { decir que se rompe el sentido } \\
\text { formidable del artículo que consagra en } \\
\text { la Nación y en la Provincia y en la vida } \\
\text { de nuestra democracia la igualdad ante } \\
\text { la ley. Con el mismo sentido podría } \\
\text { preguntar por qué nos detenemos con } \\
\text { tanto calor los hombres de todos los } \\
\text { bloques cuando hablamos del obrero; la }\end{array}$ \\
\hline
\end{tabular}




\begin{tabular}{|c|c|}
\hline $\begin{array}{l}\text { oncede a otros en igualdad de } \\
\text { ondiciones". } \\
\text { Establecer en esta Constitución } \\
\text { lisposiciones especiales sobre el } \\
\text { borigen es consagrar una diferencia } \\
\text { que lógicamente perjudica al indio. } \\
\text { Si bien la Comisión Redactora al } \\
\text { ncluir artículos referentes al indio, lo } \\
\text { ace con el propósito elevado- lo } \\
\text { econozco, señor Presidente- de } \\
\text { onseguir ventajas para él, no es menos } \\
\text { ierto que al hacerlo consagra } \\
\text { egalmente una inferioridad que lo } \\
\text { lisminuye jurídica y socialmente. }\end{array}$ & 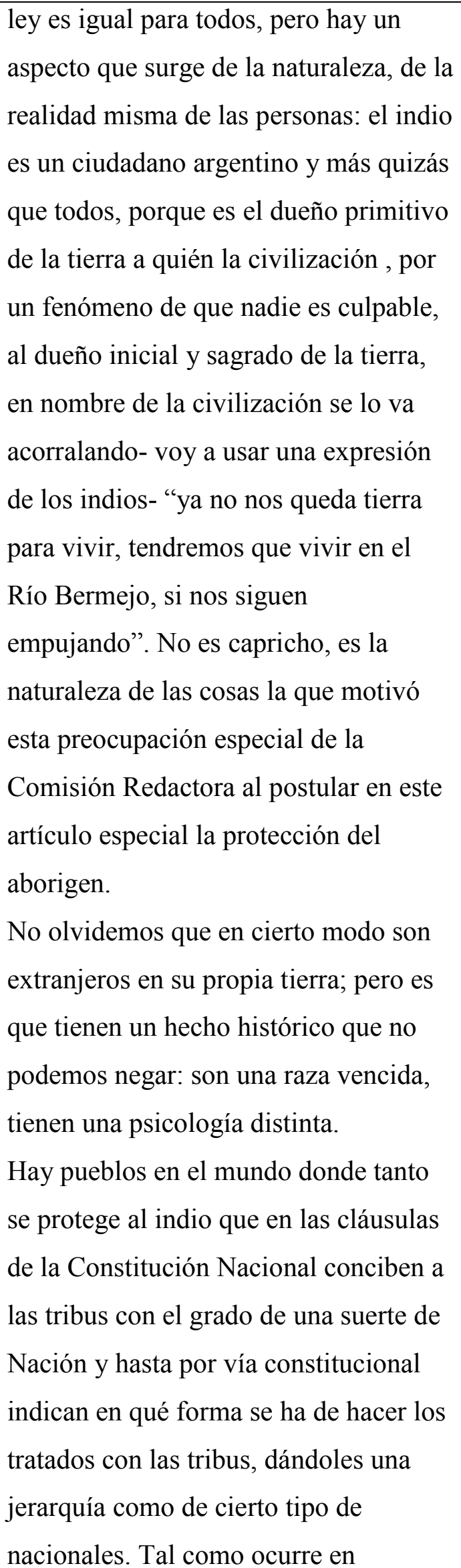 \\
\hline
\end{tabular}




\begin{tabular}{|c|c|}
\hline & $\begin{array}{l}\text { Norteamérica con los negros, aunque } \\
\text { parezca absurdo. } \\
\text { Yo pregunto cómo se justifica que hasta } \\
\text { hace poco tiempo el indio, ciudadano } \\
\text { argentino, no tuviera la obligación de } \\
\text { hacer el servicio militar. Indagué la } \\
\text { causa y se me dijo que el indio no podía } \\
\text { ser conducido en las tropas por su } \\
\text { idiosincrasia. No lo inventó la } \\
\text { Comisión Redactora: son hechos. } \\
\text { Recuerdo de los años mozos que un } \\
\text { viejo profesor nuestro decía: “a la } \\
\text { naturaleza se la vence obedeciéndole. } \\
\text { Hemos querido nada más que obedecer } \\
\text { a la naturaleza para vencerla en } \\
\text { beneficio del indio, de la idiosincrasia } \\
\text { natural del indio; y esta expresión: } \\
\text { “quedan suprimidos los sistemas de } \\
\text { misiones, reducciones u otros que } \\
\text { entrañen su diferenciación y } \\
\text { aislamiento social”, tenga la plena } \\
\text { seguridad el señor doctor Maldonado } \\
\text { que no tiene tal sentido de persecución } \\
\text { hacia la misión” }\end{array}$ \\
\hline $\begin{array}{l}\text { Por Ideología, sosteniendo las } \\
\text { misiones y reducciones }\end{array}$ & $\begin{array}{l}\text { Por Ideología, en contra de las } \\
\text { misiones y reducciones }\end{array}$ \\
\hline $\begin{array}{l}\text { "En segundo lugar destaco que no } \\
\text { apoyo ni voto el artículo porque } \\
\text { establece una distinción que no puedo } \\
\text { admitir, cuando en todo momento he } \\
\text { defendido y defenderé la libertad en } \\
\text { todo sentido. Y destaco que } \\
\text { lamentablemente este artículo establece }\end{array}$ & $\begin{array}{l}\text { Se refirió a una expresión con respecto } \\
\text { a la cual podría traer miles de testigos } \\
\text { vivientes, indios con los que he hablado } \\
\text { y deseo que me perdonen si alguien } \\
\text { cree que estoy haciendo demagogia al } \\
\text { hablar del indio, pero desde pequeño, } \\
\text { desde chico aprendí mis primeros }\end{array}$ \\
\hline
\end{tabular}


una discriminación: LA IDEOLOGÍA.

Dice el proyecto: "quedan suprimidos los sistemas de misiones, reducciones $\mathrm{u}$ otros que entrañen su diferenciación y aislamiento social".

¿Cuál es la razón de esta prohibición, señor Presidente? ¿Son los resultados obtenidos en los años de aplicación o es que se piensa que es un sistema inepto, retrógrado, perjudicial?

Con respecto a su aplicación nada más que elogios y buenos resultados podemos consignar en la obra de las misiones y reducciones.

Poco después de la conquista las tierras de América que pertenecían al dominio eminente del rey, fueron usurpados por los encomenderos. Los indios que eran vasallos del rey pero encomendados, a cargo de ser vestidos, alimentados e instruidos, fueron transformados por éstos en siervos y aún, en esclavos. $\mathrm{Y}$ es en este momento cuando llegan a América y luego a nuestro país los domínicos, jesuitas, agustinos.

Este sistema de pacificación que vino a sustituir al de la conquista por las armas y a la explotación del indio por el blanco, tuvo efectos extraordinarios. No quiero decir por esto, que todos alcanzaron el mismo éxito y esplendor. Muchas reducciones limitadas por el medio, por el carácter de los indios juegos con el indio, mucho antes de pensar o concebir que pudiera ser político algún día; pongo como ejemplo $\mathrm{y}$ acuso y reto si alguien cree que hago demagogia, que podría traer testigos vivientes y no lo hago con el propósito demagógico de traer aquí un malón, sino que podría traer la expresión vertidas por hombres sin corromper por mi influencia, de hombres de alfabeto, expresión espontánea nacida de las entrañas del indio, y que dicen: "Señor, nosotros no nacimos para vivir en cautiverio", expresión que no les enseñó nadie sino que surge de la fuerza telúrica de la raza y de la tierra, que lleva realidades como ésta.

Yo pregunto a los señores convencionales si alguno de ustedes vio un indio que tenga vocación por los servicios domésticos, por el trabajo bajo patrón o prefiere la miseria libérrima en la selva o en los desiertos donde nuestra civilización los empujo? Yo no discuto ni pienso, y al contrario, adhiero a las expresiones del señor convencional doctor Maldonado. Jamás voy a poner en tela de juicio la santa preocupación de hombres y mujeres religiosas por la suerte del indio, y no ignoro y no olvido el santo testamento de Isabel la Católica, su testamento histórico, cuando pidió que los indios fueran 


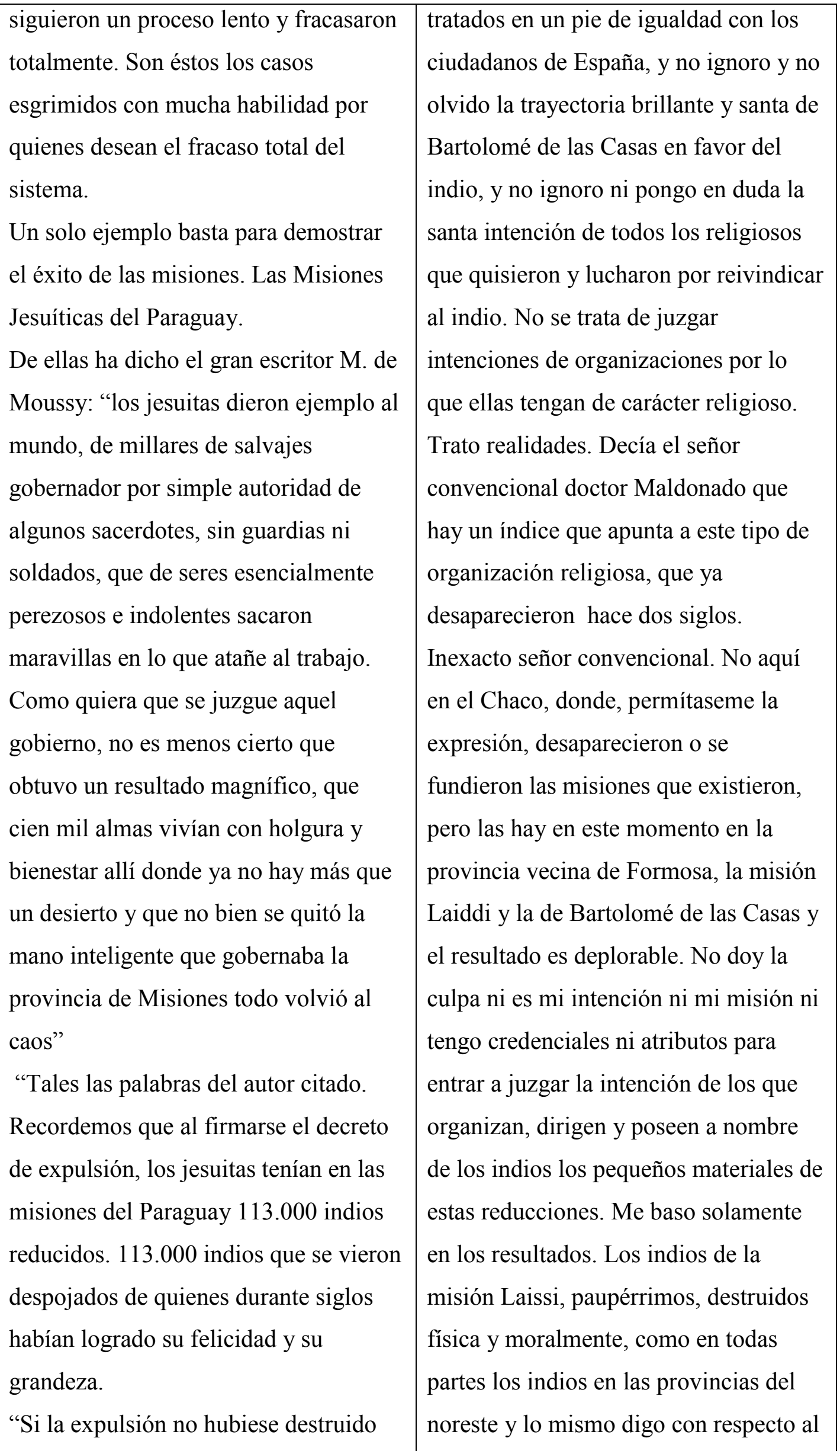


antes de alcanzar su punto de madurez, esta sabia obra de adiestramiento psicológico que los padres realizaban, acaso en una o dos generaciones habría dado a los descendientes-hijos y nietos de los indios- la cordura que a éstos les faltaba y el sistema se habría modificado o extinguido salvándose muy probablemente una obra de civilización y educación de consecuencias incalculables" dice Luis Roque Gondra, profesor de Economía en la Universidad de Buenos Aires. No creo, señor Presidente, que sean los frutos la causa de la prohibición consignada en el proyecto. Pero tampoco creo, Sr. Presidente, que sea un sistema antiguo, retrógrado, inadecuado. ¿Cómo pretendemos asimilar al indio dejándolo que viva en el medio, en la selva, con sus costumbres, con su indolencia, con desamor al trabajo? La única solución es obrar sobre ellos constantemente en todos sus actos, en todos los momentos. Es la única obra educativa eficaz. ¿Y si la educación que el indio necesita no se la puede dar la familia, cómo se pretende suplirla?

Pero lo notable, señor Presidente, que la Comisión Redactora no indica los medios de que el Superior Gobierno de la Provincia se valdrá para para sistema de reducciones, que tampoco le cuadra la expresión de que no existieron, porque aunque ahora tiene otro nombre, sigue siendo, en su sistema y método, reducción, la de Napalpí que fracasó rotunda y vergonzosamente. Nueve leguas de tierras extraordinarias, a pocos kilómetros del ferrocarril desde 1920 y tantos y el resultado, indios tuberculosos y desnutridos, sesenta niños muertos de sarampión en el invierno, absurdo de reeditar en pleno siglo 20; y pasaron y pasaron administradores y presidente y directores de la reducción: muchos de ellos fueron a Buenos Aires, donde viven ricos y el indio cada vez más humilde y pauperizado.

Este sistema se mantiene en nuestra provincia aunque haya cambiado de nombre y las autoridades han sido sordas a las sugestiones de este demagogo que fue a reclamarles justicia sin haber proclamado jamás que lo hacía. De manera, entonces que solamente la intención, y soy en gran manera responsable de este artículo, ha sido ir contra el sistema que precisamente hace lo que no quiere que se haga el señor convencional doctor Maldonado: el aislamiento y el tratarlo de forma diferente. Es un sistema de 


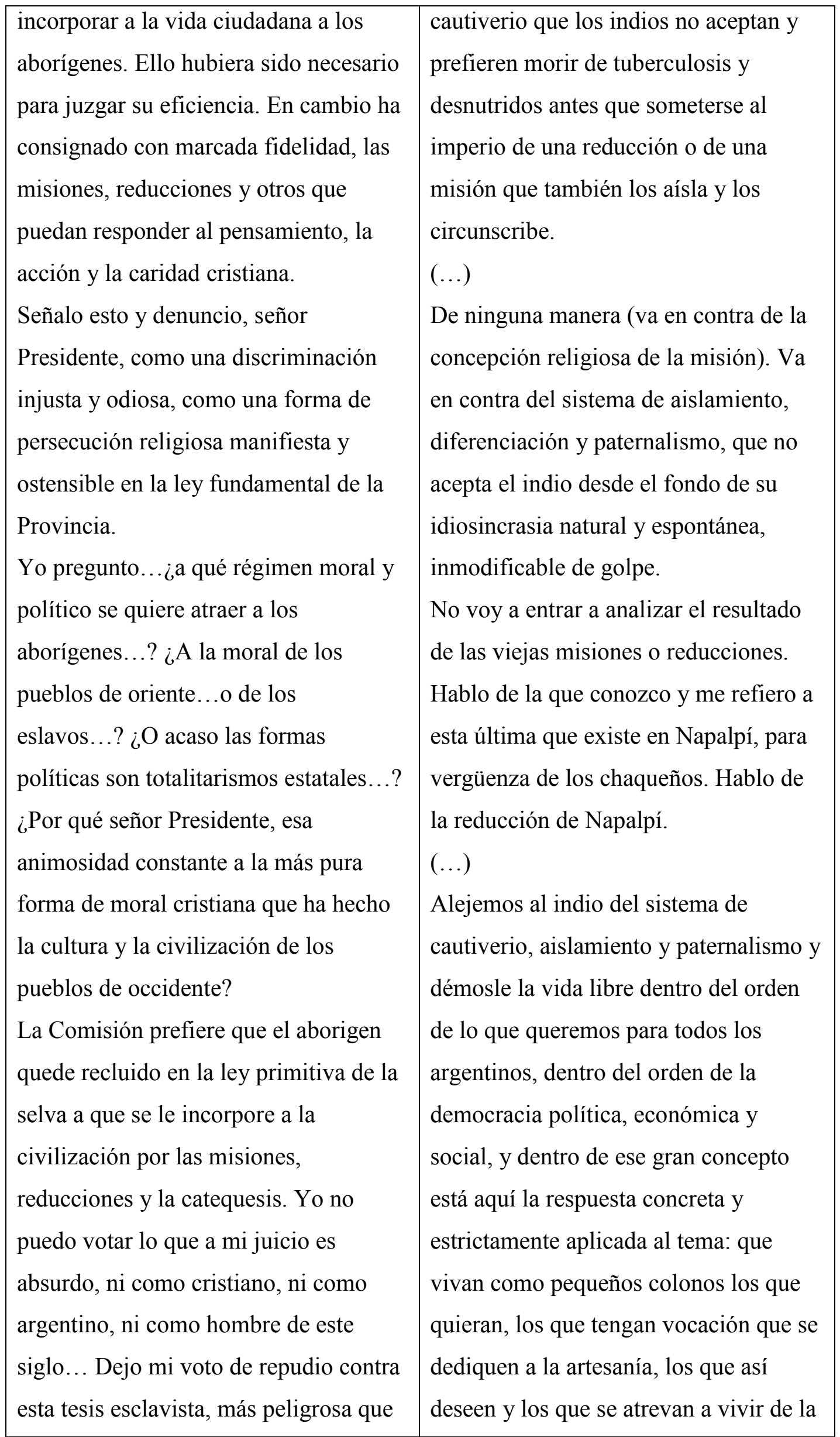




\begin{tabular}{|c|c|}
\hline $\begin{array}{l}\text { a servidumbre corporal. } \\
\text { Y si la Honorable Convención creyera } \\
\text { que con ello afecto algún privilegio- } \\
\text { or afirmar mi libertad de pensamiento } \\
\text { de conciencia-... por usar del derecho } \\
\text { que tiene el último ciudadano en los } \\
\text { aaíses libres...y se me lo limita...o si, } \\
\text { como ya existe precedente, se juzgara } \\
\text { que afecto privilegios- lo que jamás he } \\
\text { nensado- puede V.H empezar la } \\
\text { nstrucción. Pero tenga la seguridad, } \\
\text { eñor Presidente, de que por encima de } \\
\text { os programas partidarios que puedan } \\
\text { ustituir los señores convencionales, les } \\
\text { econozco honor y la conciencia de los } \\
\text { nismos, puestos al servicio de la Patria } \\
\text { y de la Provincia del Chaco liv,. }\end{array}$ & $\begin{array}{l}\text { caza y de la pesca, que vivan, pero } \\
\text { dentro de un régimen de libertad y de } \\
\text { recuperación pacífica }{ }^{\mathrm{lv}} \text {. } \\
\text { Aplausos en las bancas y en la barra } \\
\text { A las exposiciones a favor del artículo } \\
34 \text {. Como fue propuesto por la } \\
\text { Comisión Redactora. } \\
\text { Diario de sesiones } 30 \text { de noviembre de } \\
\text { 1957, } 21,10\end{array}$ \\
\hline
\end{tabular}




\section{Derechos indígenas 1994.}

El pedido del establecimiento en la Constitución de la cantidad de tierras a entregarse a las comunidades indígenas fueron planteadas en las notas enviadas, ingresadas como asuntos entrados, cuya lectura se dio antes del tratamiento del artículo 34 en plenario.

La lectura de asuntos entrados corresponde a las reglas de interacción de la Convención Constituyente. Se dictó un reglamento interno.

El reglamento interno establece normas generales: "de los convencionales; de las sesiones en general; de las autoridades; de los secretarios; de las comisiones; de la presentaciones de los proyectos; de las mociones; del uso de la palabra; de la Convención en comisión; de la discusión en sesión; de la discusión en general; de la discusión en particular; del orden de la sesión; disposiciones generales sobre la sesión y la discusión; de la votación; del diario de sesiones; de la observancia y reforma del reglamento; de la sanción y juramento de la Constitución" (Abraham: 2011)

\section{Asuntos entrados: Actores y organizaciones en apoyo a la entrega de tierras}

\section{3/10/94:}

- Prelatura de Humahuaca, Jujuy; Monseñor Juan Carlos Maccarone, obispo titular de Mauriana y auxiliar de Lomas de Zamora;

- la Iglesia Evangélica Valdense, de Colonia San Gustavo, La Paz, Entre Ríos;

- la Coordinadora del Equipo de Pastoral Aborigen de la Conferencia Episcopal Argentina de Formosa;

- la Diócesis de San Roque, de Presidencia Roque Sáenz Peña;

- la Parroquia San Antonio, de Tres Isletas;

- los representantes de las organizaciones de Medanitos y Tatón;

- la Asociación de Familias de Pequeños Agricultores de los Altos A.F.P.A.L.A.-, de Catamarca;

- la Parroquia San José, de Sáenz Peña, firmado por el párroco Rubén Sandi;

- Obispado de Viedma;

- Del Sindicato de Empleadas Domésticas de Catamarca-S.E.DO.CA.-; 
- Del Equipo Nacional de Pastoral Aborigen, de Buenos Aires;

- del Instituto Cristianos Bienvenidos los Pobres -Be.Pe.- y

- de la Fundación para el Desarrollo en Justicia y Paz -FUNDAPAZ-.

\section{Despachos: características comunicativas}

Los proyectos de reforma de artículos se enviaron a comisiones temáticas o de tópicos. En el caso del artículo 34 intervinieron las Comisiones de Preámbulo, Principios Generales, Derechos Individuales, Civiles, Sociales, Políticos y Garantías.

Esta comisión, como las demás, guardó representación por partido político. Su tarea fue aconsejar la redacción del artículo a la asamblea Constituyente.

Se produjeron dos despachos. Uno de mayoría (por votos de miembros) y otro de minoría

A continuación, se representó en un cuadro para su mejor visualización:

\begin{tabular}{|l|l|}
\hline Despacho de mayoría & Despacho de minoría \\
\hline $\begin{array}{l}\text { "La Provincia reconoce la preexistencia } \\
\text { de los pueblos indígenas y su identidad } \\
\text { étnica y cultural }\end{array}$ & $\begin{array}{l}\text { "La Provincia reconoce la preexistencia } \\
\text { de los pueblos indígenas, su identidad } \\
\text { étnica y cultural }\end{array}$ \\
\hline $\begin{array}{l}\text { Y la propiedad comunitaria inmediata } \\
\text { de la tierra que poseen en la actualidad } \\
\text { y las otorgadas en reserva }\end{array}$ & $\begin{array}{l}\text { Y la propiedad, individual, comunitaria } \\
\text { ocupan en la actualidad y las otorgadas } \\
\text { en reserva }\end{array}$ \\
\hline $\begin{array}{l}\text { Y regulará la entrega de otras aptas } \\
\text { suficientes para el desarrollo humano }\end{array}$ & $\begin{array}{l}\text { Asegurando su protagonismo a través } \\
\text { de sus propias instituciones }\end{array}$ \\
\hline $\begin{array}{l}\text { Las exceptúa de todo gravamen, serán } \\
\text { inembargables, imprescriptibles }\end{array}$ & $\begin{array}{l}\text { Las tierras serán entregadas como } \\
\text { reparación histórica, en forma gratuita, } \\
\text { exentas de todo gravamen, serán } \\
\text { inembargables, indivisibles e } \\
\text { intransferibles a terceros }\end{array}$ \\
\hline
\end{tabular}




\begin{tabular}{|c|c|}
\hline $\begin{array}{l}\text { El Estado asegurará: } \\
\text { a)La educación bilingüe e intercultural } \\
\text { b) La participación en la protección, } \\
\text { preservación, conservación y } \\
\text { recuperación de sus recursos naturales y } \\
\text { de los demás intereses que los afecten } \\
\text { asegurando su desarrollo sustentable } \\
\text { c) Propender a su elevación socio- } \\
\text { económica con planes adecuados }\end{array}$ & $\begin{array}{l}\text { El estado garantizará a las comunidades } \\
\text { indígenas de la Provincia } \\
\text { a)La entrega en propiedad comunitaria } \\
\text { de las tierras fiscales existentes, en } \\
\text { calidad y extensión suficiente, no } \\
\text { inferior a } 630.000 \text { ha para desarrollo } \\
\text { humano } \\
\text { b) La educación bilingüe e intelectual } \\
\text { c) La participación en el uso, } \\
\text { preservación y recuperación de los } \\
\text { recursos naturales y de los demás } \\
\text { intereses que los afecten, el equilibrio } \\
\text { ecológico del hábitat (...) Las tierras } \\
\text { serán entregadas como reparación } \\
\text { histórica. }\end{array}$ \\
\hline $\begin{array}{l}\text { Convencionales: } 5 \\
\text { 3- A.Cha (Partido provincial fundado } \\
\text { por el último gobernador de la } \\
\text { dictadura) } \\
\text { 2- UCR }\end{array}$ & $\begin{array}{l}\text { Convencionales: } 4 \\
\text { PJ }\end{array}$ \\
\hline
\end{tabular}

\section{Games}

Las exposiciones se iniciaron por los miembros informantes para después pasar a la discusión en general y particular.

Las reglas de interacción ejecutadas fueron: el cuarto intermedio (para las negociaciones y acuerdos), las mociones de orden para volver al tema o solicitar la votación, si se considera agotado el debate. Son estrategias discursivas de ese tipo de frame 
Constitución de 1957. Artículo 34 (sujeto a reforma): "La Provincia protegerá al aborigen por medio de una legislación adecuada que conduzca a su integración en la vida nacional y provincial, a su radicación en la tierra, a su elevación económica, a su educación y a crear la conciencia de sus derechos, deberes, dignidad y posibilidades emergentes de su condición de ciudadano. Quedan suprimidos los sistemas de misiones, reducciones, $u$ otros que entrañen su diferenciación y aislamiento social”,

\begin{tabular}{|c|c|}
\hline Despacho de Mayoría & Despacho de minoría \\
\hline Miembro informante: GRBAVAC & Miembro Informante: COLOMBO \\
\hline $\begin{array}{l}\text { Propiedad: Se otorguen en } \\
\text { propiedad, en juicio sumario, a las } \\
\text { comunidades que las soliciten.(No en } \\
\text { el texto constitucional }\end{array}$ & $\begin{array}{l}\text { Propiedad: el derecho a la propiedad } \\
\text { de las tierras que actualmente ocupan } \\
\text { y las otorgadas en reserva, como } \\
\text { también en calidad y extensión } \\
\text { suficiente, no inferior a } 730 \text { mil } \\
\text { hectáreas, o al } 30 \text { por ciento de las } \\
\text { tierras fiscales existentes, junto con } \\
\text { los recursos naturales que en ellas } \\
\text { existen (En el texto constitucional) }\end{array}$ \\
\hline $\begin{array}{l}\text { "Si analizamos la situación por la que } \\
\text { vinimos y volvemos la vista a nuestro } \\
\text { alrededor, veremos un pavoroso drama } \\
\text { de miseria que soporta la gente } \\
\text { humilde, los pequeños productores y en } \\
\text { especial los aborígenes que deben } \\
\text { luchar a diario para sobrevivir en un } \\
\text { ambiente hostil, muchas veces falto de } \\
\text { lluvias y otras en exceso, en tierras que } \\
\text { no son aptas y, como si esto fuera poco, } \\
\text { una bárbara explotación de su trabajo }\end{array}$ & $\begin{array}{l}\text { "El reconocimiento a su identidad } \\
\text { étnica y cultural, a la personalidad } \\
\text { jurídica de las comunidades aborígenes, } \\
\text { el derecho a la propiedad de las tierras } \\
\text { que actualmente ocupan y las otorgadas } \\
\text { en reserva, como también en calidad y } \\
\text { extensión suficiente, no inferior a } 730 \\
\text { mil hectáreas, o al } 30 \text { por ciento de las } \\
\text { tierras fiscales existentes, junto con los } \\
\text { recursos naturales que en ellas existen. } \\
\text { Esto es con la finalidad de que, de acá }\end{array}$ \\
\hline
\end{tabular}




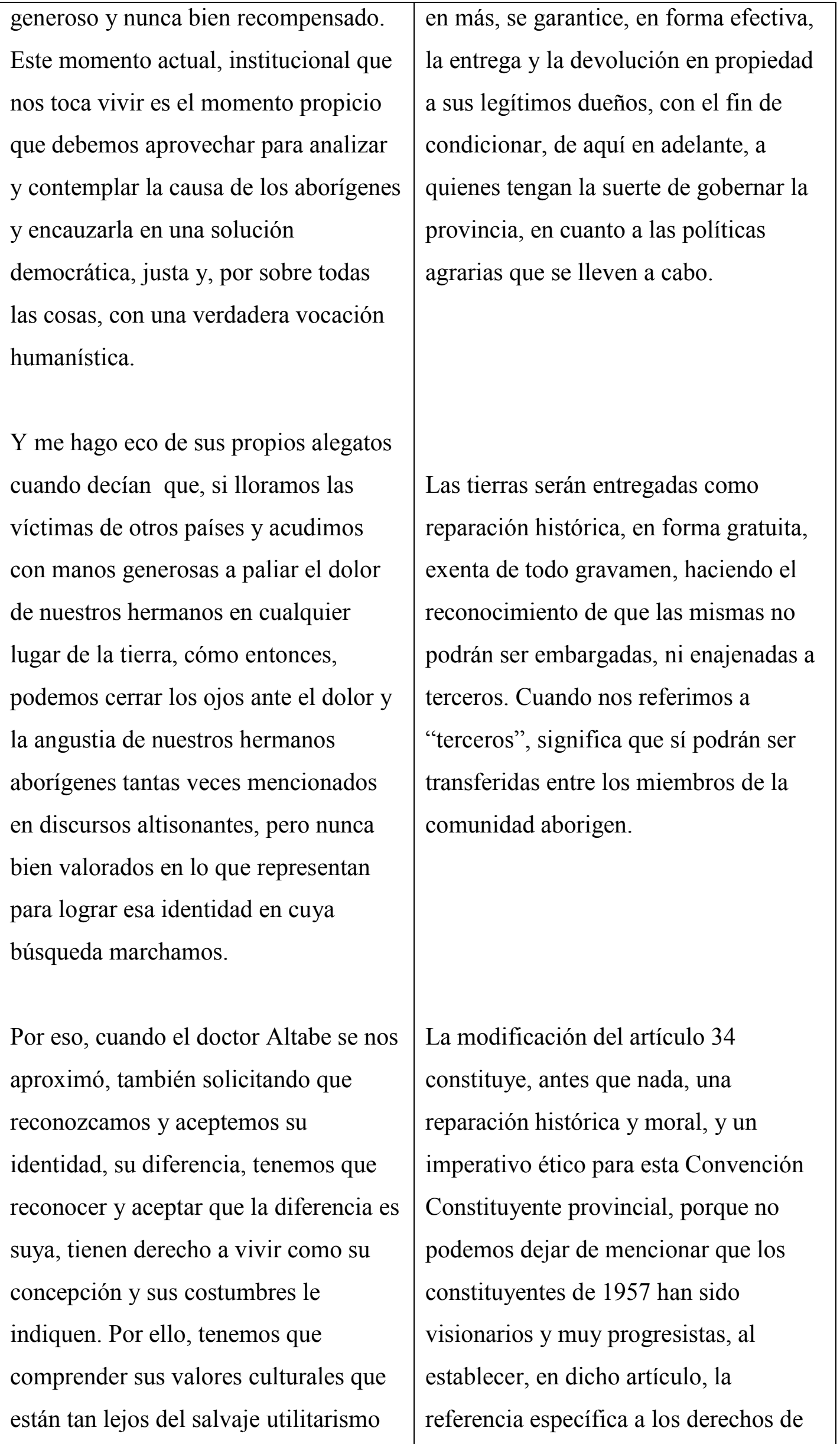




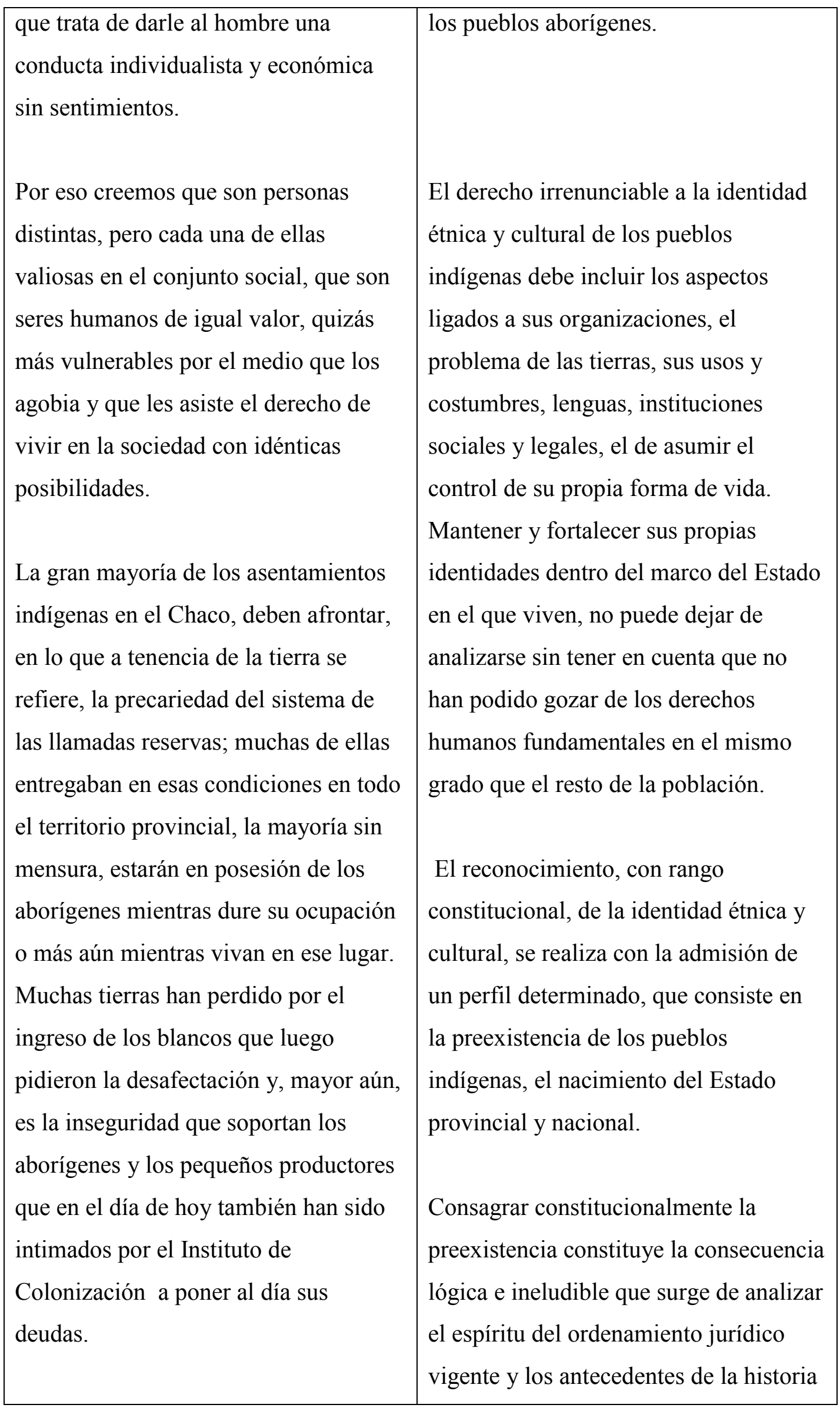




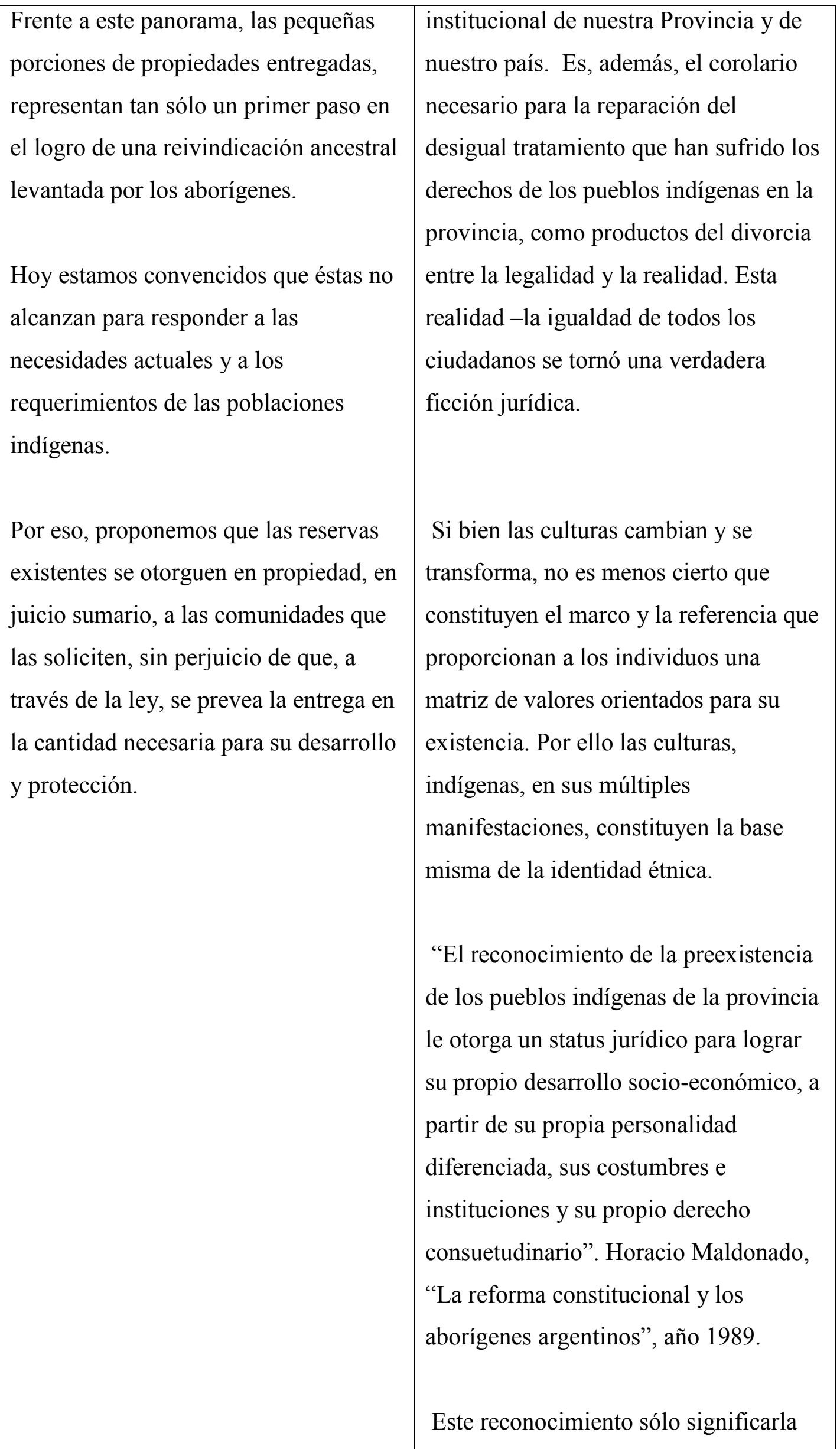




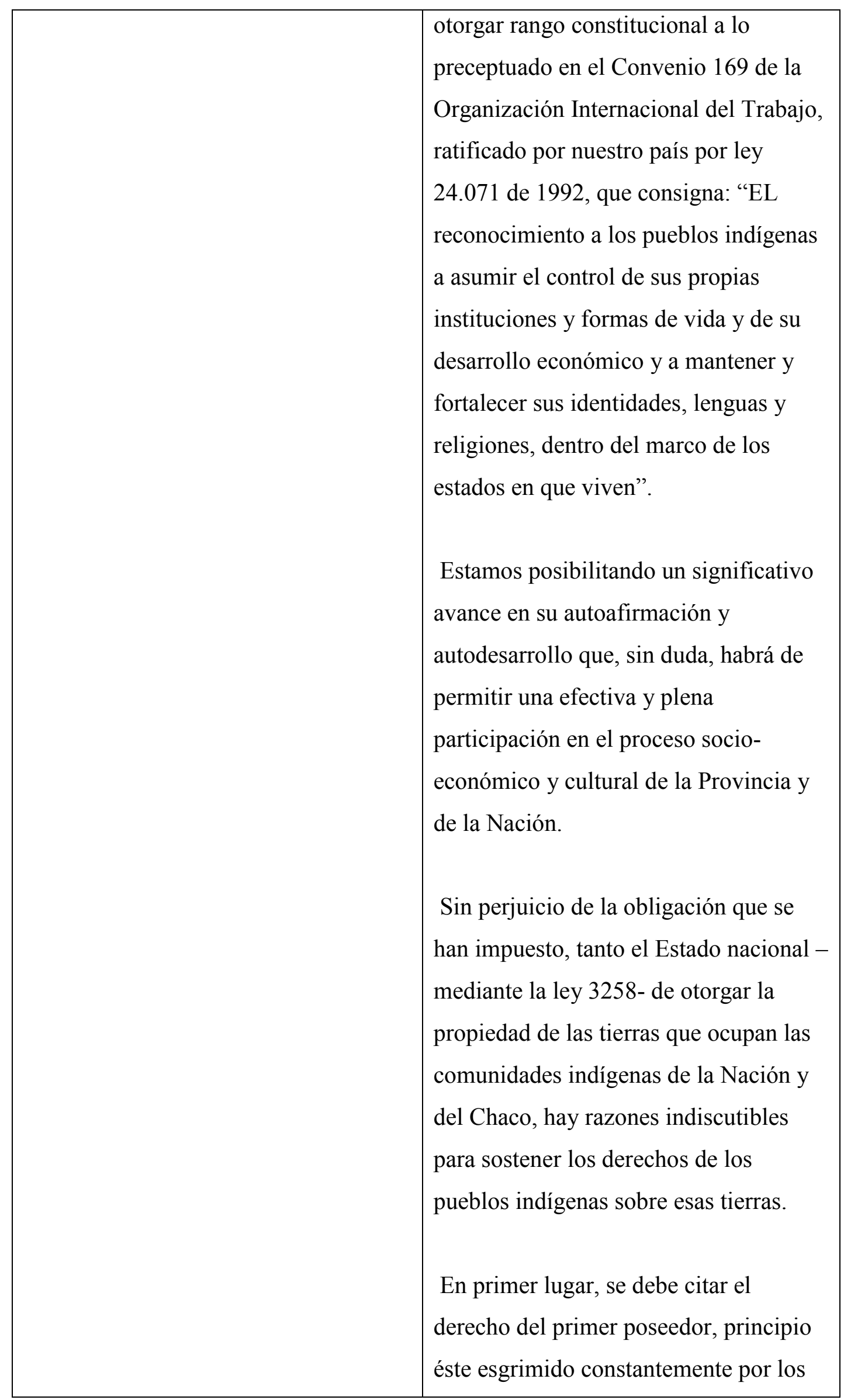




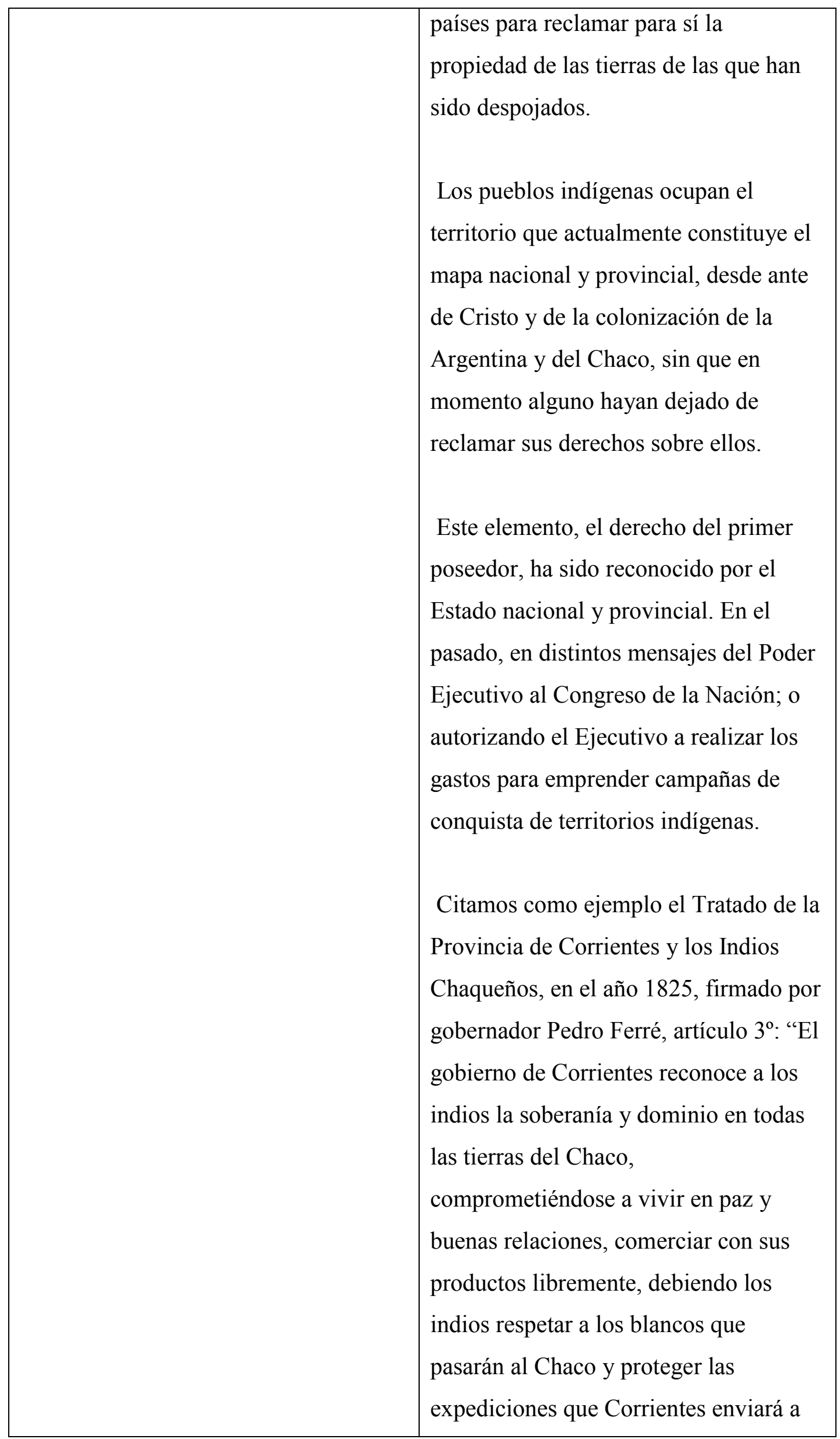




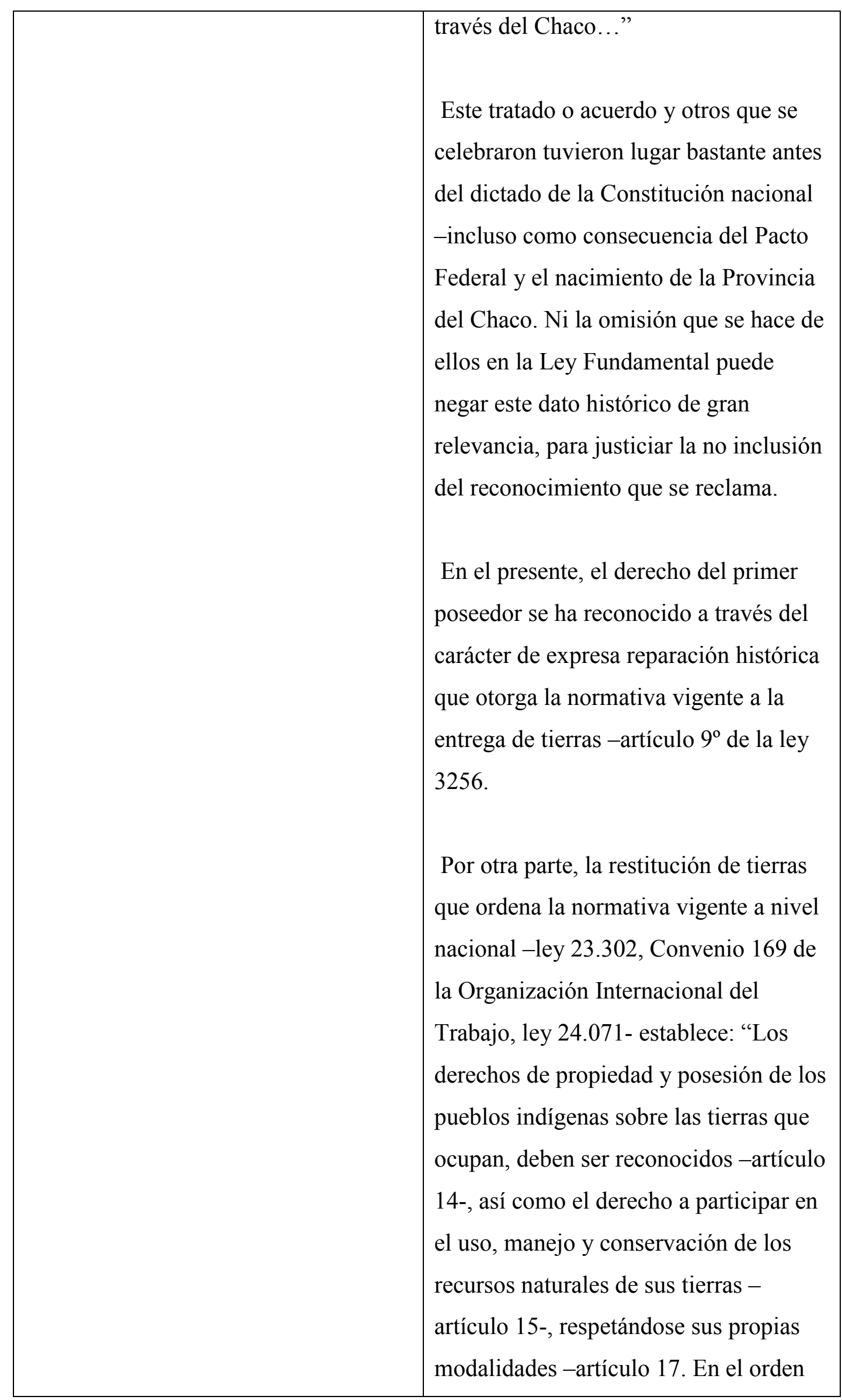




\begin{tabular}{|c|c|}
\hline & $\begin{array}{l}\text { provincial, la ley } 3258 \text { debe hacerse, } \\
\text { según lo dispuesto por tales normas, en } \\
\text { los lugares que actual o ancestralmente } \\
\text { ocupan las comunidades aborígenes de } \\
\text { la provincia". }\end{array}$ \\
\hline $\begin{array}{l}\text { Preexistencia, reconocimiento étnico } \\
\text { y cultural }\end{array}$ & $\begin{array}{l}\text { Preexistencia, reconocimiento étnico } \\
\text { y cultural }\end{array}$ \\
\hline $\begin{array}{l}\text { Dichas tierras serán entregadas como } \\
\text { reparación histórica, en forma gratuita, } \\
\text { exenta de todo gravamen; serán } \\
\text { inembargables, imprescriptibles, } \\
\text { indivisibles e intransferibles a terceros. } \\
\text { Si bien es cierto que no hay un censo } \\
\text { reciente de la cantidad de población } \\
\text { indígena, también es verdad que } \\
\text { muchas etnias se han perdido y otras } \\
\text { están diezmadas. } \\
\text { De acuerdo con el desarrollo de los } \\
\text { acontecimientos, el futuro de los } \\
\text { aborígenes estará ligado al museo, } \\
\text { donde los héroes serán los } \\
\text { conquistadores, o, tal vez, quedarán } \\
\text { reducidos a un país exótico, o al } \\
\text { discurso hipócrita de algunas } \\
\text { autoridades, que busquen las raíces de } \\
\text { la argentinidad que supimos destruir. } \\
\text { Todo apunta, en la mejor de las } \\
\text { hipótesis, a la asistencia provisoria, } \\
\text { hasta que ellos se integren a nuestra } \\
\text { civilización, y la política oficial parece }\end{array}$ & $\begin{array}{l}\text { La política constitucional que preside el } \\
\text { despacho puesto a consideración del } \\
\text { plenario, tiene como criterios rectores, } \\
\text { antes que nada, como primer punto, el } \\
\text { expreso reconocimiento de la } \\
\text { preexistencia de los pueblos indígenas, } \\
\text { en la formación del estado nacional y } \\
\text { provincial. } \\
\text { Otro criterio es el derecho a la propia } \\
\text { organización; a su reconocimiento } \\
\text { jurídico; a su protagonismo, a través de } \\
\text { sus instituciones, y a decidir siempre su } \\
\text { propio destino. }\end{array}$ \\
\hline
\end{tabular}


ser así.

En la práctica, los aborígenes no se integran, están allí, y luchan para quedarse, expulsados de sus tierras en forma compulsiva, saqueados en el fruto de su trabajo.

Por ello, los comprendemos. Sabemos que luchan para continuar, para seguir siendo ellos mismos; Por eso, reconocemos su preexistencia y su identidad étnica y cultural, y además, tenemos que generar un acto de solidaridad con las poblaciones autóctonas, y una afirmación de sus valores nativos.

Cuando hablamos del indio en los homenajes, los recordamos muy bien, pero en definitiva, no hemos resuelto los problemas que afectan a los primitivos dueños de estas tierras.

Siempre ha habido criterios dispares, pero ninguno se ha plasmado en realidades efectivas, como para integrar al indio a la comunidad, con toda la fuerza humanística que es darle reconocer para estos seres marginados. A la población indígena hay que dignificarla, asistirla y reconocer su aporte a la vida social y económica de nuestra provincia. 


\begin{tabular}{|c|c|}
\hline $\begin{array}{l}\text { Por eso, mientras ensalzamos a los } \\
\text { indígenas en los actos públicos, ellos } \\
\text { viven marginados, con altos índices de } \\
\text { enfermedades y desnutrición”. }\end{array}$ & \\
\hline Educación bilingüe e intercultural & Educación bilingüe e intercultural \\
\hline $\begin{array}{l}\text { La educación apenas llega hasta ellos, } \\
\text { y van perdiendo sus costumbres y su } \\
\text { idioma, que es la base de la } \\
\text { supervivencia cultural de los pueblos. } \\
\text { Por eso decimos que "el Estado } \\
\text { asegurará la educación bilingüe e } \\
\text { intercultural”, porque mientras en } \\
\text { forma literaria se prestigia al indio, en } \\
\text { la práctica es la carne viva de las tareas } \\
\text { más pesadas, o bien vive en el más } \\
\text { completo abandono, supeditado a la } \\
\text { ayuda de alguna institución. } \\
\text { Por ellos, no bastan las ayudas } \\
\text { electoralistas, ni las promesas. Hay que } \\
\text { erradicar el hambre, las necesidades, } \\
\text { las enfermedades; crear fuentes de } \\
\text { trabajo; ayudarlos para el desarrollo de } \\
\text { su propia cultura; elevarlos en la } \\
\text { consideración de la sociedad. }\end{array}$ & $\begin{array}{l}\text { Es que la historia misma de la } \\
\text { colonización y de la relación entre el } \\
\text { colonizante y el colonizado, nos permite } \\
\text { distinguir dos componentes: O bien se } \\
\text { piensa que los indígenas son seres } \\
\text { humanos completos, que tienen los } \\
\text { mismos derechos que el colonizador, en } \\
\text { cuyo caso se las ve igual, y también } \\
\text { idéntico, y entonces, esta conducta nos } \\
\text { lleva hacia el asimilacionismo. Es decir, } \\
\text { a la proyección de nuestros propios } \\
\text { valores en los demás, con } \\
\text { desconocimiento absoluto de las } \\
\text { diferencias, o bien se puede partir de las } \\
\text { diferencias, pero ésta se traduce, } \\
\text { inmediatamente, en términos de } \\
\text { superioridad o de inferioridad, negando } \\
\text { la existencia de una sustancia humana } \\
\text { realmente otra, que puede no ser simple } \\
\text { estado perfecto de uno mismo. }\end{array}$ \\
\hline & $\begin{array}{l}\text { Ambas figuras elementales de la } \\
\text { experiencia, de la realidad, que han } \\
\text { marcado al proceso de la colonización y } \\
\text { aún hoy se mantiene, descansan en un }\end{array}$ \\
\hline
\end{tabular}




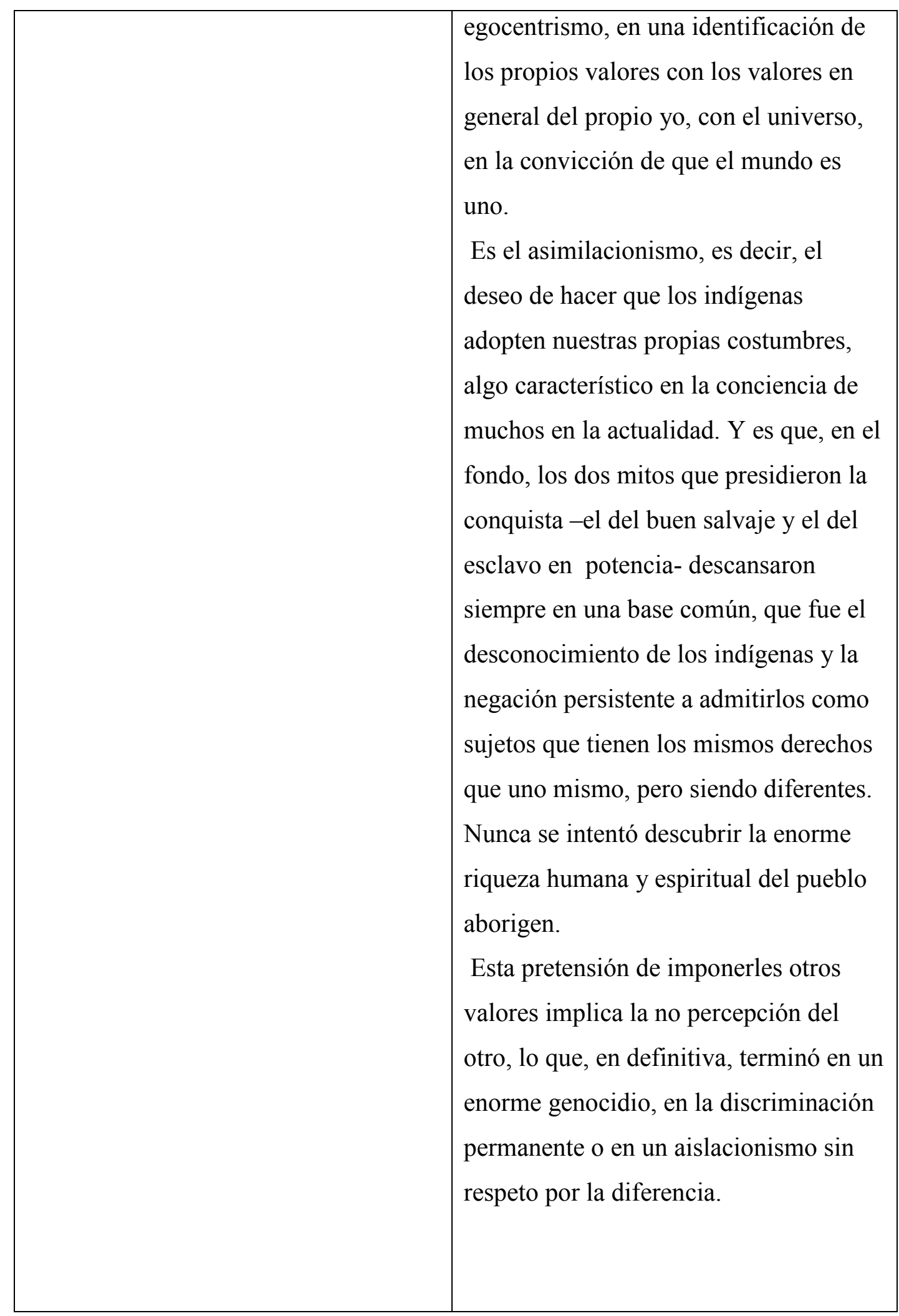


1994. Artículo sancionado.

“Artículo 34.- La Provincia reconoce la preexistencia de los pueblos indígenas y su identidad étnica y cultural, la personería jurídica de sus comunidades y la propiedad comunitaria e inmediata de la tierra que poseen en la actualidad y las otorgadas en reserva, y regulará la entrega de otras aptas y suficientes para el desarrollo humano. Las mismas se entregarán como reparación histórica, en forma gratuita, exenta de todo gravamen. Serán inembargables, imprescriptibles, indivisibles e intransferibles a terceros.

EI Estado asegurará: a) La ecuación bilingüe e intercultural; b) La participación en la protección, preservación, conservación y recuperación de sus recursos naturales y de los demás intereses que los afecten, asegurando su desarrollo sustentable; c) Propender a su elevación socio-económica con planes adecuados".

La matriz comunicacional y jurídica del cuarto intermedio

Las normas convencionales y las leyes pueden aprobarse en general. Esa salida se da en los casos donde el debate fue agotado y se pacta un cuarto intermedio, para la redacción legal.

No hubo cambios en ninguno de los miembros de las bancadas, por lo cual el extenso debate que continuó replicó las falacias en torno con maniobras extraargumentales (por ejemplo un ataque personal), e incluyó también los falsos argumentos que se emplean con la intención de engañar o desviar la atención (por ejemplo la falacia ad ignorantiam, la pista falsa o las apelaciones emocionales), como ya fue citado.

No se realizan registros en los diarios de sesiones de las conversaciones en el cuarto intermedio. Esta es una regla comunicacional y jurídica.

Respecto de las falacias por demagogia, los convencionales agotaron todas las instancias de expresar su solidaridad y comprensión con los pueblos originarios. 
En ese cuarto intermedio, se apeló a la salida de la cláusula transitoria, que como ya se describió es para de las reglas de interacción y significa que no habiendo consenso para modificar el texto constitucional, se realiza una declaración de principios y se deja los aspectos operativos a la Legislatura, es decir la entrega de tierras.

Tras ese acuerdo, se pasó a otro ritual que es la discusión en particular, donde se definieron las palabras y sus asignaciones de sentido. Por tanto, es una práctica discursiva que busca reducir al máximo posible la polisemia.

DISCUSIÓN EN PARTICULAR: “Se atribuye al discurso argumentativo: resolver una diferencia de opinión respecto de la aceptabilidad de un punto de vista. Por otra, se espera que el procedimiento sea intersubjetivamente válido sobre la base de consideraciones también pragmáticas: puesto que el sistema de reglas ofrece una oportunidad para resolver eficazmente una diferencia de opinión, en principio, tal sistema debería ser aceptado por quienes se interesan en resolver una diferencia ${ }^{\text {lvi," }}$

La sesión discutió casi cinco horas el artículo 34 sin cambiar la posición sobre la determinación de las 730 mil hectáreas o el 30\% de las tierras fiscales de la Provincia.

El cuarto intermedio transcurrió entre las 21,50 y las 23,01 (Diario de sesiones). 1 hora y 51 minutos 


\begin{tabular}{|c|c|}
\hline Palabra & Significado atribuido \\
\hline $\begin{array}{l}\text { Personería jurídica, en lugar de } \\
\text { Personalidad jurídica. Se cambió en } \\
\text { la discusión en particular. }\end{array}$ & 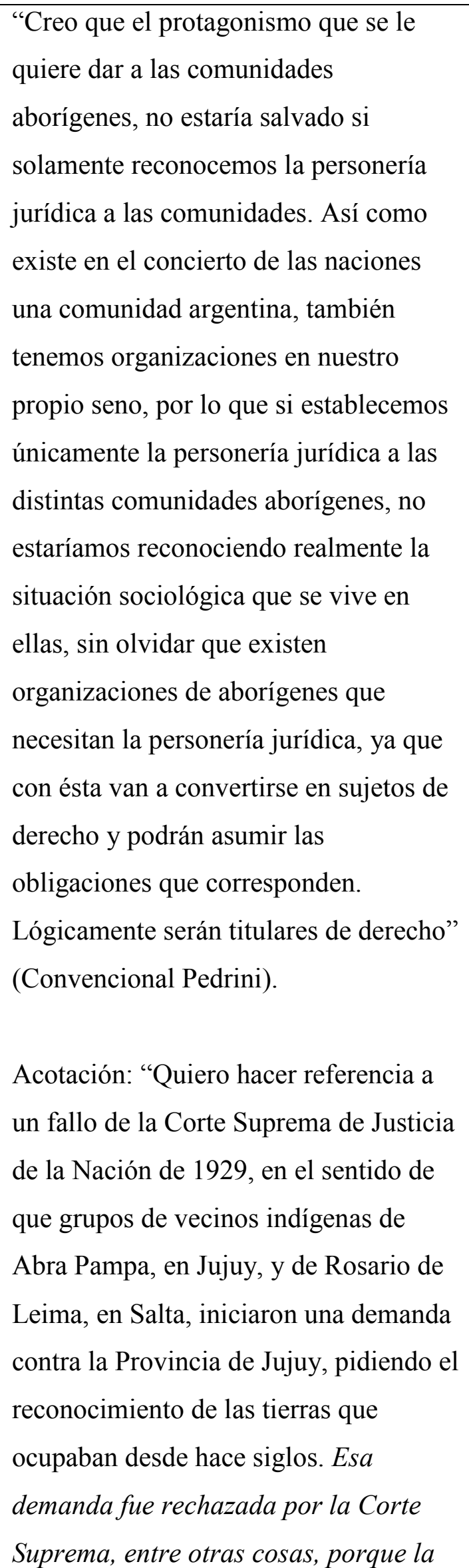 \\
\hline
\end{tabular}




\begin{tabular}{|c|}
\hline $\begin{array}{l}\text { Corte sostuvo que las comunidades } \\
\text { aborígenes carecían de personería } \\
\text { jurídica. } \\
\text { La referencia jurídica que significa una } \\
\text { legitimación para actuar ante los Podes } \\
\text { públicos, es la personería y no la } \\
\text { personalidad. (Convencional Leunda) } \\
\text { “En la Provincia del Chaco no hay } \\
\text { fallos que establezcan que la } \\
\text { personalidad equivale a la personería } \\
\text { jurídica necesaria para litigar. } \\
\text { Destaco que no nos impulsa el ánimo } \\
\text { de debatir bizantinamente sobre el } \\
\text { particular, pero los hombres de derecho } \\
\text { sabemos que lo que nos habilita para } \\
\text { litigar, para peticionar a las autoridades, } \\
\text { lo que es un derecho elemental de } \\
\text { cualquier ciudadano y organización, es } \\
\text { la personería jurídica” (Convencional } \\
\text { Leunda) }\end{array}$ \\
\hline
\end{tabular}




\begin{tabular}{|l|l|}
\hline $\begin{array}{l}\text { Ocupación de la tierra, no posesión. } \\
\text { "Que tradicionalmente ocupan" }\end{array}$ & $\begin{array}{l}\text { "Cuando hablan de la tierra que poseen } \\
\text { en la actualidad, se refiere a la que han } \\
\text { ocupado tradicionalmente. } \\
\text { Eso se entiende, no como una } \\
\text { posesión del Código Civil, sino la } \\
\text { posesión en el concepto tradicional } \\
\text { que ellos tienen, y que creo que fue lo } \\
\text { que permitió lograr el consenso en la } \\
\text { comisión". (Colombo) } \\
\text { "Propongo que se coloque la palabra } \\
\text { "ocupan" en lugar de "poseen", ya que } \\
\text { "ocupan" es una figura distinta" } \\
\text { (Abraham, acompañada de Pedrini y } \\
\text { Sotelo (PJ); Leunda (UCR) }\end{array}$ \\
\end{tabular}

\begin{tabular}{|l|l|}
\hline Reparación histórica & "Y otro párrafo para establecer que \\
serán entregadas como reparación \\
histórica salvo mejor criterio". \\
(Colombo (PJ), aprobado)
\end{tabular}

De la discusión en particular, solo participaron los convencionales abogados.

El pedido de las organizaciones y asociaciones indígenas, sociales y religiosas fue de 1 millón de hectáreas. El despacho de minoría (PJ) propuso 730 mil. Se optó por el uso de la cláusula transitoria, por lo cual el proceso, hasta 2016 sigue demorado. "Lo más importante en cualquier discusión es saber de qué se discute. Son muy frecuentes los errores motivados porque se abandona (o permitimos que se abandone) la cuestión para introducir otro debate. Cuando esto sucede decimos que se incurre en una falacia de Eludir la cuestión (DAMBORENEA: 2016)" También por el requerimiento de la figura de asociación civil para la propiedad. Reparación histórica, no tiene una definición jurídica sino es de uso metafórico, consecuente con los discursos expuestos. 
El convencional Quiroga- lego y militante de las organizaciones indígenasexpuso al final de la discusión del articulado: "Señor presidente: Es al sólo efecto de comparar esta sesión con la de Villa Ángela (donde se aprobó la imposibilidad de privatizar las empresas estatales).

En Villa Ángela, se fueron un montón de familias contentas por haber logrado el objetivo perseguido; esta noche, seguramente, una comunidad se va un poco triste, igual estado de ánimo tiene quien les habla. Nada más”. 
Comparación de matrices constitucionales. Las Constituciones del Chaco de 1951,1957 y 1994

\begin{tabular}{|c|c|c|}
\hline Constituciones & Concepción de Estado & Concepción de indígena \\
\hline 1853 & $\begin{array}{l}\text { Estado- Nación } \\
\text { (Territorio Nacional del } \\
\text { Chaco) }\end{array}$ & $\begin{array}{l}\text { Anulación de la } \\
\text { pertenencia identitaria } \\
\text { mediante su exterminio o } \\
\text { integración }\end{array}$ \\
\hline 1951 & Estado social & $\begin{array}{l}\text { Trabajador sin distinción } \\
\text { de identidades étnicas, } \\
\text { culturales y sociales }\end{array}$ \\
\hline 1957 & $\begin{array}{ll}\text { Estado } & \text { socialista } \\
\text { utópico- } & \text { pequeña } \\
\text { burguesía agraria }\end{array}$ & $\begin{array}{l}\text { Colonización } \\
\text { incorporación como } \\
\text { mano de obra para la } \\
\text { cosecha de algodón y } \\
\text { caña de azúcar. }\end{array}$ \\
\hline
\end{tabular}

\begin{tabular}{|l|lr|l|}
\hline 1994 & Estado liberal con & Introducción del concepto \\
algunas regulaciones & del cmulticulturalidad" \\
económicas & & posmoderno \\
\hline
\end{tabular}

La propiedad de la tierra pública es un tema medular para el capitalismo. El territorio nacional del Chaco fue entre 1875 y 1951 objeto de las mayores expoliaciones. Con la Forestal instalada, la tala del quebracho en busca del tanino, substancia para ablandar y procesar cueros, conformó un imperio con la anuencia del Estado Nacional y congruente con sus principios.

La colonización se inició con violencia y se sostuvo por su uso.

Esta posibilidad de discusión de los derechos indígenas, se inscribe en la definición de la palabra fingida o la pragmática del mentir.

Ninguna facción de poder iba a ceder el 30\% de las tierras fiscales del Chaco en manos de comunidades indígenas. Era un asunto de matriz de poder, de metalenguaje retórico. 
Hasta los convencionales que se opusieron, salvo uno, de mucha trayectoria compartida con las comunidades indígenas (Convencional Quiroga), sabía era falacia. Por ello anticipó que la cláusula transitoria no sería operativa.

Por otra parte, se incluyó el enunciado "reparación histórica".

No existe esa figura en la legislación. Es una falacia.

Tampoco la personalidad sino la personería jurídica, que obligó a las comunidades indígenas a organizarse en asociaciones civiles para acceder a las tierras "que ocupan".

No existe en la figura de propiedad comunitaria.

Existe la propiedad horizontal, la propiedad en condominio, etc.

La propiedad que el Estado entrega a una Asociación Civil, otorgada en donación, puede retirarla si no cumple los fines. Pensando en la pirámide jurídica, se supone que en este caso, hay protección especial a las comunidades indígenas.

Pero no existe derecho hereditario.

Por lo tanto, está negada la identidad de las familias que componen los clanes indígenas. Hipotéticamente, no podrán transmitir sus derechos, como el resto de los ciudadanos argentinos sobre la porción de tierra que tienen a su nombre en una escritura.

\section{Sobre la forma jurídica moldeada por la retórica}

La estrategia de ocultamiento fue la pluriculturalidad. El reconocimiento histórico y la preexistencia de los pueblos indígenas, fue un argumento demagógico para consolidar el Estado Nación, fundado en 1853 y sostenido desde entonces.

Se utilizó el nombre de propiedad comunitaria como sinónimo de asociación civil. Se cumplieron operaciones discursivas en torno del significante.

Fue la ratificación de una matriz económica, donde la producción y reproducción es el único modo de nombrar al trabajo desde la matriz capitalista.

Si la política no es soberana, respecto de la subsistencia, es economía política y no política económica.

La reforma constitucional del Chaco- 1994- evidenció en su discusión parlamentaria la histórica disputa por las tierras fiscales, que cuenta con numerosos antecedentes. 
En términos económicos, el período de 1951 hasta 1953, marcó el desarrollo pleno de la producción algodonera.

El "oro blanco", decía Guido Miranda en 1955. "La industria nacional absorbe la producción textil con lo que la región no sufre recesión durante ese período; es más el desarrollo de la industrialización permite una mejor distribución del ingreso, lo que hace posible su expansión permanente hasta 1953. Se produce una mayor participación de los asalariados en el ingreso nacional (48,6\% en 1940, $52,8 \%$ en 1952) lo que configura, a la par de un aumento absoluto de la mano de obra industrial, aumentos en los salarios, especialmente en el período peronista"(...) Señalemos que el crecimiento ininterrumpido de la producción algodonera en esta etapa se desarrolla a través de períodos cíclicos de precios bajos, originados por el oligopsonio organizado sobre la base de las empresas comercializadoras. Parte de este poder monopólico fue roto, en principio por el movimiento cooperativo, aunque el mejor período para el productor fue el que corresponde a la actividad del IAPI (Instituto de Promoción del Intercambio creado mediante el decreto 15.350 del 28 de mayo de 1946). (...)En esta fase se configura la base de pequeños y medianos productores (...) La tenencia caracteriza una mayoría de ocupantes fiscales.

En ese mismo censo (1947) las explotaciones de hasta 25 hectáreas son el 33,3\%; de 26 a 100; 17 hectáreas el 49,9\% y de 101 y más 15,6\%. El período de posguerra significó para el Chaco el inicio de la crisis forestal, crisis que se extiende y profundiza hacia fines de la década del '50". (Miranda: 1955)

Discutir el régimen de tierras fue discutir sobre los derechos indígenas. Justamente el derecho a la tierra, es el derecho conculcado por la colonización. Indígenas y tierras son parte de una misma cosmovisión.

La posesión de la tierra como recurso, es una discusión propia del proceso capitalista, no forma parte de las concepciones de los pueblos indígenas. No hubo cambios en la estructura ni manejo de la tierra pública, orientada a su explotación intensiva y asociada al trabajo, desde la concepción capitalista.

La efectiva entrega de las 730.000 ha para las comunidades indígenas, requerían la organización en Asociaciones Civiles, modo de personería jurídica que desencadenó varios conflictos posteriores por las dificultades en su constitución.

La propiedad comunitaria fue establecida como una expresión de deseos, sin base jurídica. En lo fáctico, como una cláusula de protección hacia la venta individual 
de tierras, no quedando en claro, sobre los derechos hereditarios salvo que se mantenga la Asociación a cuyos integrantes se dio las tierras, en representación de las comunidades originarias.

Por tanto, quedó para discusión posterior si este tipo de asociación velará por los derechos de las comunidades o se transformará en otro cascarón jurídico susceptible de ser permeado, en el futuro por decisiones de los nuevos integrantes societarios.

La reforma de 1994 utilizó en juego retórico el enunciado "reparación histórica", porque esta reparación no tiene forma jurídica, sino fue respuesta una coyuntura de presión política de las organizaciones indígenas, acompañadas por varias prelaturas de la Iglesia Católica y otras Iglesias de diversos credos.

A diferencia del plebiscito por la privatización o no de los servicios públicos de la provincia, que ameritó un mandato de la ciudadanía a los convencionales, la discusión sobre la propiedad de las tierras de las comunidades indígenas quedó librada a la posición de las bancadas políticas y a la opinión dividida dentro de las bancadas políticas.

Es un punto interesante, porque remite a la discusión sobre la propiedad de la tierra, hito fundacional del sistema capitalista.

Creencias, valoraciones, subjetividades puestas en juego en torno de la reparación histórica a las comunidades indígenas.

El marco legal argentino no proporciona más que mediante el establecimiento de Institutos que garantizan el derecho de minorías, la condición de la diversidad cultural y étnica, sin afectar el derecho a la propiedad instituido por la Constitución de 1853 donde la nacionalidad es la única categoría existente, en torno del sentido de ciudadanía.

La misma utilización sinonímica de "pueblos originarios" y "comunidades originarias" lo mostró. Solo pueden ser reclamados derechos emergentes como derechos de minorías y no como pueblos, porque sería cambiar el status de Nación, unificada tras la batalla de Caseros.

No era posible considerar la existencia de una Nación o varias naciones indígenas dentro de la Nación Argentina.

Entonces, es el derecho de las minorías, con una protección especial pero que no se extiende a las relaciones de propiedad. 
El pensamiento humano tras los genocidios, y los sistemas políticos que los aceptaron, se caracterizaron en la sociedad occidental por la necesidad del perdón. De pedir perdón y otorgar reparación.

Esta reparación es declamativa, no garantiza otro derecho que el de la visibilidad y la aceptación de lo diferente.

Los trabajadores son actores del sistema económico, en la legislación argentina, no los indígenas.

Las tierras fiscales, siguiendo el discurso legislativo, siguen siendo orientadas a la colonización.

Por tanto, los indígenas, sea cual fuere su modo de organización, participan como islas, reservas de lo étnico y lo cultural.

Si la entrega de tierras fiscales en el futuro contempla como primera finalidad la colonización, entonces, será entregada a quienes son capaces de explotarlas, que no son indígenas.

La relación con la tierra por parte de los indígenas no es capitalista.

Son formaciones pre-capitalistas, y en el caso del Chaco, de recolección y caza y no de cultivo, como los indígenas del NOA.

No era necesario para la subsistencia de los pueblos qom, mocoit y wichí pensar en la agricultura porque el alimento estaba dado en los animales y los frutos. En los ríos y bañados.

Tampoco era necesario un desarrollo civilizatorio y arquitectónico porque no son climas fríos, sino subtropicales.

Los clanes se unían a efectos de las guerras, primero contra otros clanes indígenas y mucho después contra la invasión blanca.

El alimento y el reposo eran dados en la convivencia con la tierra y como parte de ella.

Este razonamiento es hoy una utopía.

Este caso mostró que la representación política no puede, no está dispuesta o no quiere a alterar matrices capitalistas.

El sistema político- en 1994- dio evidencias de su permeabilidad a la economía de mercado. El Chaco, por ser una provincia periférica, pudo avanzar en un reconocimiento de índole reparatorio.

Tal discusión en la Pampa húmeda, dudo posible. 
Los territorios del Norte argentino son los que tienen más población indígena porque el modo que el capitalismo llegó a esas tierras fue tomando las extensiones productivas.

Dejando para inicios del siglo XX, las entonces improductivas a las poblaciones indígenas e integrándolas al trabajo en la cosecha del algodón y la caña de azúcar. No se procedió al exterminio total por necesidad de mano de obra barata y poco calificada. Sin caciques, en una estructura clánica, los demás integrantes de ellos quedaban sin guía y sin posibilidad de reacción.

Al momento de finalizar esta investigación (2016), con la extensión de la frontera agrícola y la tecnificación de la agricultura, se verá qué ocurre.

En la discusión de la reforma de 1994 triunfó la burguesía y adaptó las formas jurídicas que velasen por la propiedad.

Concatenaciones metonímicas que pasaron desapercibidas por los periódicos estudiados, por naturalización de sus términos.

También para los convencionales, en tanto sujetos, por su constitución sociohistórica.

La debilidad de la representación política se evidenció en la reforma del 1994, con la fuerza del debate sobre la economía, que es la subsistencia.

En el caso de los derechos indígenas sobre las tierras que ocupan, fue un debate demagógico en términos aristotélicos y de refuerzo del régimen de verdad, en términos de Focault.

La Convención, en la discusión de los Derechos Indígenas, fue una falacia, no pudo garantizar promesa ni contrato. Como actividad institucionalizada no pudo determinar "quién, cuándo y cómo puede, o debe o no debe llevarse a cabo una promesa" (Yañez: 2008)

Radicalmente intervino el contexto por vía de clausura discursiva.

$\mathrm{Su}$ contexto de discusión estaba impregnado por "la ideología liberal contemporánea" que "oculta la realidad sociohistórica del régimen establecido. Oculta el agorá, una cuestión decisiva, la del fundamento y de la correspondencia antropológica de toda política y de todo régimen. (...) El contenido antropológico en el individuo contemporáneo no es otra cosa que la expresión o la realización concreta, en carne y hueso, del imaginario social central de la época, que moldea el régimen, su orientación, los valores, aquello por lo cual vale la pena vivir o morir, el empuje de la sociedad, incluso sus afectos" (Castoriadis: 2006). 
La convocatoria de la reforma del '94, tuvo claros propósitos: incorporar enmiendas que permitiesen "el juego del mercado", en términos de desregulación, de oligopolio liberal.

Cumplió su cometido. 


\section{3) Prensa gráfica chaqueña}

\section{Presentación de los diarios chaqueños}

\section{- NORTE}

Diario Norte fue fundado el 1 de julio de 1968. Su primer propietario fue Juan Carlos Rosselout, dirigente justicialista. En los inicios de la dictadura de 1976 el diario es expropiado y puesto a la venta.

Adquirió la propiedad del medio la familia Romero Feris, y el presidente de la SA es Raúl "Tato" Romero Feris, ex gobernador de la Provincia de Corrientes, entre otros cargos públicos, líder del Partido Autonomista, partido provincial, que después atravesó diversos cambios en su denominación. Al momento de finalizar esta investigación, cumple prisión domiciliaria, por delitos en contra del Estado, enriquecimiento ilícito y causas similares.

Norte comienza a discutir el liderazgo en las ventas a El Territorio a partir de los ' 80.

Desde fines de los años 80 hasta 2012 es el primer diario en número de lectores y también de referencia dominante en la prensa gráfica. Mantiene el manejo del Directorio la familia Romero Feris.

Su director desde hace más de 30 años es Miguel Angel Fernández.

\section{- $\quad$ EL DIARIO}

El Diario fue fundado en 1990. Su primer propietario fue Jorge Michilo, empresario de la construcción, con tratos con el Estado a través de la obra pública, durante la dictadura de 1976.

En 1992, vende el diario a un grupo de empresarios de la construcción de la provincia de Formosa. Este proceso dura unos pocos meses y se vuelve a vender el medio a un empresario vinculado a la administración de pooles de empresas vinculadas como proveedoras del Estado.

Bernardo Balbuena era el propietario y director del diario en 1994, al momento de discutirse la reforma constitucional. Mantuvo la conducción de la empresa hasta el 1 de octubre de 2002, cuando se decreta la quiebra, tras un proceso de vaciamiento que implicó su descapitalización y profundos conflictos con los trabajadores por retrasos de meses en el pago de salarios hasta llegar a la 
suspensión completa de pagos a los trabajadores y proveedores. Los trabajadores decidieron continuar con el diario y el 22 de octubre de 2002 nació la cooperativa de trabajo y consumo La Prensa Ltda., que un mes después, es decir el 22 de noviembre, ya explotaba elDIARIO de la Región, la primera y única empresa recuperada de la región nordeste que edita un diario.

La organización adoptó los pasos que siguieron las empresas recuperadas en todo el país: reclamar la expropiación de los bienes, que fue votada en mayo de 2005 por la Cámara de Diputados. En el camino, la cooperativa adopta un nuevo sistema de organización cooperativo para su principal producto: el diario.

\section{Producción periodística: Selección y jerarquización del acontecimiento.}

El tema "Derechos indígenas en la Convención Constituyente, no tuvo espacio redaccional en las tapas de ninguno de los dos diarios estudiados, en el período de discusión parlamentaria ni al momento de la sanción de la modificación del artículo 34.

Operó el principio de omisión/ inclusión. En este caso, omisión de las tapas de la prensa gráfica,

\section{Operaciones de simplificación}

Los periódicos estudiados, cumplieron su tarea de mediación vía operaciones de simplificación en el debate constitucional de 1994.

No dieron entidad al debate que involucró a los Derechos Indígenas y la entrega de tierras. El formato utilizado fue la crónica y no fue jerarquizado en las tapas. Los núcleos significativos noticiables fueron los siguientes: 


\begin{tabular}{|c|c|c|}
\hline $\begin{array}{l}\text { Núcleos } \\
\text { significativos }\end{array}$ & Diario Norte & El Diario \\
\hline $\begin{array}{l}\text { Cobertura } \\
\text { de inicio }\end{array}$ & $\begin{array}{l}\text { Nota } 1 \\
\text { Producción periodística: } \\
\text { Organización: mosaica. } \\
\text { Ubicación redaccional: Pag.13, } \\
\text { cabeza de página. } 8 \text { de } \\
\text { septiembre de } 1994 . \\
\text { Técnica periodística: } \\
\text { Jerarquización (dos primeros } \\
\text { párrafos, en orden de arriba } \\
\text { hacia abajo): } \\
\text { Discurso periodístico: } \\
\text { Volanta: “Acuerdo para el } \\
\text { artículo } 34 ” \\
\text { Título: “LOS ABORIGENES } \\
\text { TENDRÁN ACCESO } \\
\text { INMEDIATO A LA } \\
\text { PROPIEDAD COMUNITARIA } \\
\text { DE LA TIERRA QUE } \\
\text { OCUPAN” } \\
\text { "Los aborígenes de la provincia } \\
\text { del Chaco tendrán derecho al } \\
\text { acceso inmediato de las tierras } \\
\text { que ocupan, en propiedad } \\
\text { comunitaria a partir de la } \\
\text { aprobación de la redacción } \\
\text { acordada ayer del nuevo texto } \\
\text { del artículo } 38 \text { de la } \\
\text { Constitución Provincial. El } \\
\text { principio estará- incluido en la } \\
\text { prarta Magna de la } \\
\text { Puáz del acuerdo }\end{array}$ & $\begin{array}{l}\text { Producción periodística: } \\
\text { Organización: mosaica. } \\
\text { Ubicación redaccional: Pag.9, } \\
\text { recuadro, pie de página.13 de } \\
\text { septiembre de } 1994 . \\
\text { Técnica periodística: } \\
\text { Recuadro- información anexa, } \\
\text { complementaria a los demás } \\
\text { temas de discusión de la } \\
\text { Convención Constituyente } \\
\text { Discurso periodístico: } \\
\text { Título: “El reclamo aborigen” } \\
\text { “Gerónimo Alvarez, Andrés } \\
\text { Lencina y Pedro Gómez, } \\
\text { dirigentes de la etnia Toba, } \\
\text { integrantes de la Mesa de } \\
\text { Organizaciones e Instituciones } \\
\text { para la Reforma, en diálogo } \\
\text { con El Diario, y respecto al } \\
\text { principal punto de tratamiento } \\
\text { de la Convención } \\
\text { Constituyente hoy en General } \\
\text { San Martín señalaron que } \\
\text { “sabemos que desde la } \\
\text { comisión salieron dos } \\
\text { despachos; uno por mayoría } \\
\text { suscripto por Acción } \\
\text { Chaqueña y el radicalismo, y } \\
\text { el otro por minoría del } \\
\text { despachos, tienen principios }\end{array}$ \\
\hline
\end{tabular}




\begin{tabular}{|c|c|}
\hline 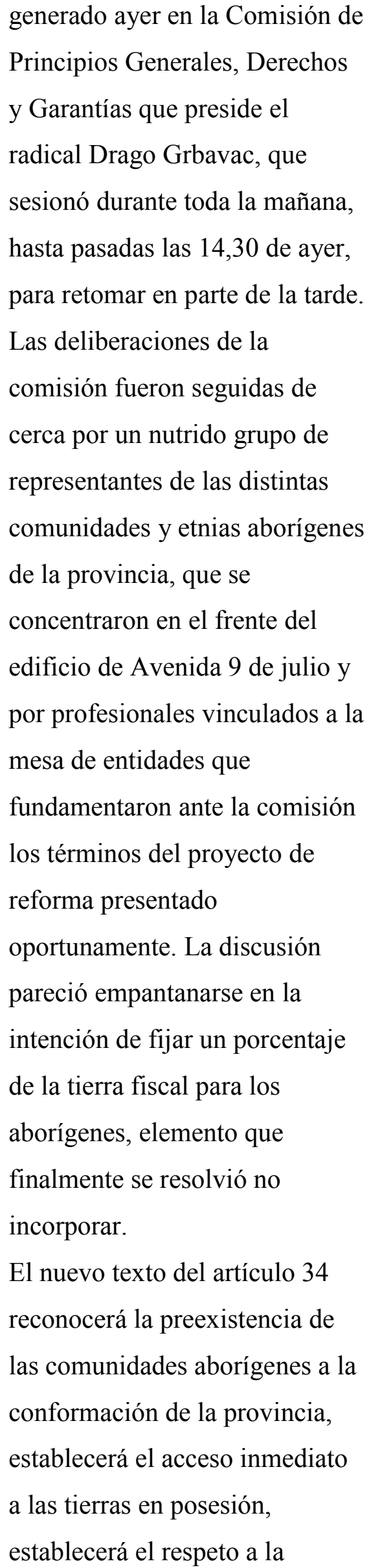 & 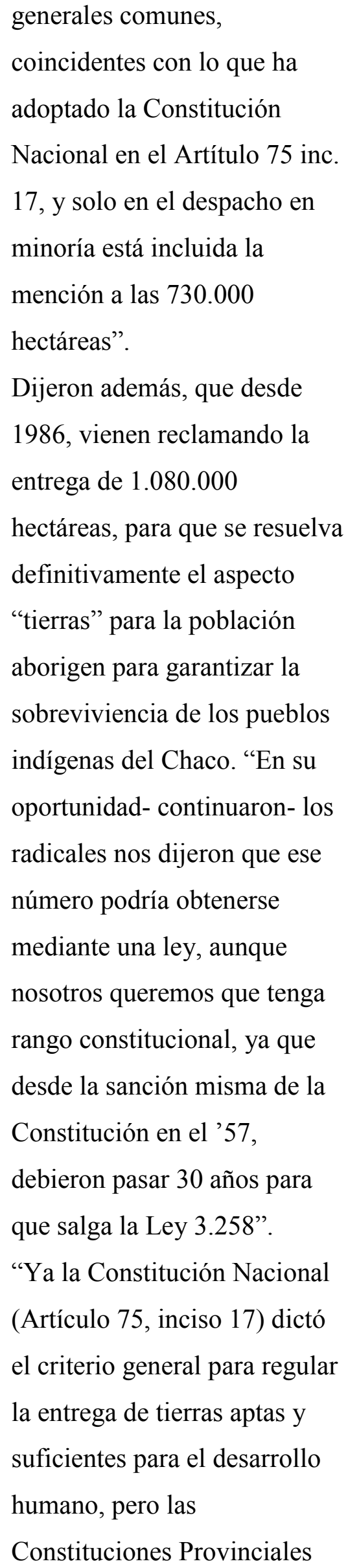 \\
\hline
\end{tabular}




\begin{tabular}{|c|c|c|}
\hline & $\begin{array}{l}\text { identidad cultural de las etnias, } \\
\text { establecerá la obligatoriedad de } \\
\text { la educación bilingüe y fijará la } \\
\text { responsabilidad del Estado en la } \\
\text { promoción de políticas que } \\
\text { aseguren el desarrollo de las } \\
\text { comunidades". } \\
\text { Games discursivos: metonimia: } \\
\text { asociación de significantes } \\
\text { etnias, aborígenes, comunidades. } \\
\text { Fuentes: Oficiosas, } \\
\text { convencionales constituyentes } \\
\text { justicialistas }\end{array}$ & $\begin{array}{l}\text { deben hoy aplicar este criterio } \\
\text { a su realidad" aclararon. } \\
\text { Por este motivo, y ante la } \\
\text { importancia del tema a abordar } \\
\text { hoy por la Convención, } \\
\text { concretaron una gran } \\
\text { convocatoria a los hermanos } \\
\text { aborígenes- de todas las } \\
\text { etnias- para que concurran hoy } \\
\text { a General San Martín, para } \\
\text { defender sus legítimos } \\
\text { derechos". } \\
\text { Games discursivos: } \\
\text { metonimia: etnias, aborígenes, } \\
\text { indígenas, tobas. } \\
\text { Fuente: Dirigentes indígenas }\end{array}$ \\
\hline $\begin{array}{c}\text { Núcleo } \\
\text { dramático }\end{array}$ & $\begin{array}{l}\text { Nota } 2 \\
\text { Producción periodística: } \\
\text { Organización: mosaica. } \\
\text { Ubicación redaccional: Pag.10, } \\
\text { subtítulo en nota. } 13 \text { de octubre } \\
\text { de } 1994 . \\
\text { Técnica periodística: Subtítulo } \\
\text { final de nota } \\
\text { Discurso periodístico: } \\
\text { Subtítulo: "Deciden en San } \\
\text { Martín los derechos aborígenes" } \\
\text { "La Convención Constituyente } \\
\text { provincial decidirá hoy cuando } \\
\text { se constituya en General San } \\
\text { Martín a partir de las } 17, \text { en qué }\end{array}$ & \\
\hline
\end{tabular}




\begin{tabular}{|c|}
\hline 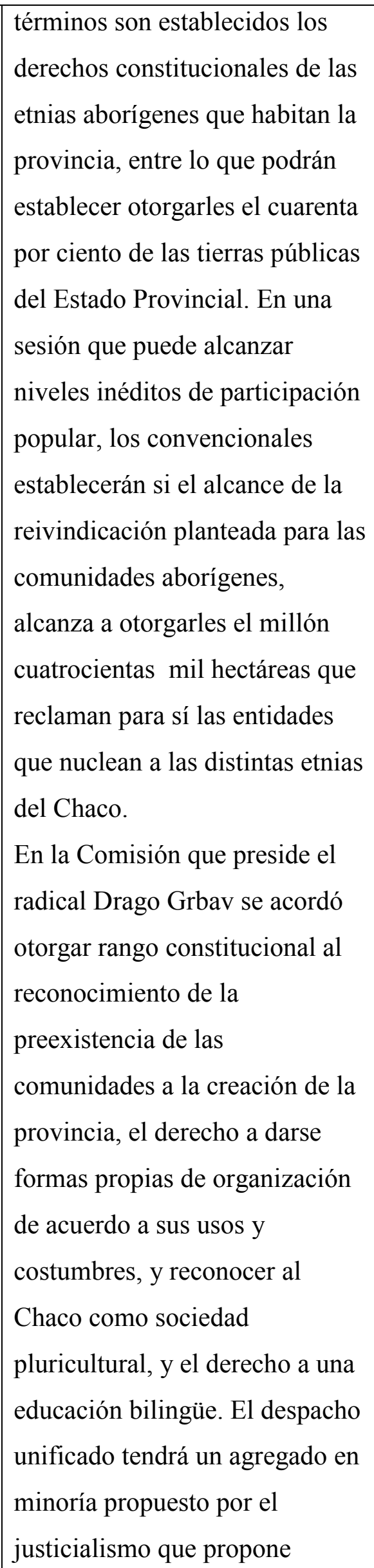 \\
\hline
\end{tabular}




\begin{tabular}{|c|c|c|}
\hline & $\begin{array}{l}\text { entregar a los aborígenes } \\
\text { chaqueños más de } 700.000 \\
\text { hectáreas de tierra pública, } \\
\text { aproximadamente la mitad de lo } \\
\text { reclamado por las entidades que } \\
\text { los nuclean" } \\
\text { Games discursivos: "podrán } \\
\text { establecer" la entrega del } 40 \% \\
\text { de la tierra pública o } 700.000 \text { ha. } \\
\text { Verbo en futuro, no potencial. } \\
\text { No se evaluó la suma de votos } \\
\text { para adelantar la posición en la } \\
\text { Convención. } \\
\text { Fuente: oficiosa, } \\
\text { convencionales constituyentes } \\
\text { justicialistas. }\end{array}$ & \\
\hline Epílogo & $\begin{array}{l}\text { Nota } 3 \\
\text { Producción periodística: } \\
\text { Organización: mosaica. } \\
\text { Ubicación redaccional: Falsa } \\
\text { central. Pag.2 y3, a título } \\
\text { desplegado. } 14 \text { de septiembre } \\
\text { de 1994, con fotos } \\
\text { (convencionales en cuarto } \\
\text { intermedio). } \\
\text { Técnica periodística: } \\
\text { Jerarquización principal, dos } \\
\text { primeras páginas del diario. } \\
\text { Título desplegado, con fotos. } \\
\text { Discurso periodístico: } \\
\text { Título: “Sin definición en } \\
\text { General San Martín sobre la }\end{array}$ & $\begin{array}{l}\text { Nota } 2 \text { : } \\
\text { Discurso periodístico } \\
\text { Producción periodística: } \\
\text { Organización: mosaica. } \\
\text { Ubicación redaccional: Pag.8, } \\
\text { cabeza de página. } 15 \text { de } \\
\text { octubre de } 1994 . \\
\text { Técnica periodística: falsa } \\
\text { central, desplegada, con } \\
\text { fotos (indígenas). } \\
\text { Volanta: “Insertaron una } \\
\text { cláusula transitoria” } \\
\text { Título: “La Convención } \\
\text { reconoció los derechos } \\
\text { indígenas pero no fijó la } \\
\text { cantidad de tierra a }\end{array}$ \\
\hline
\end{tabular}




\begin{tabular}{|c|c|}
\hline $\begin{array}{l}\text { tierra para aborígenes" } \\
\text { “Los convencionales } \\
\text { constituyentes no se ponían de } \\
\text { acuerdo, al cierre de esta } \\
\text { edición, sobre la forma en que se } \\
\text { debía indicar en el artículo } 34 \text { de } \\
\text { la Constitución Provincial, la } \\
\text { cantidad de tierra que } \\
\text { pertenecería a los aborígenes. En } \\
\text { la provincia existen } 2.400 .000 \\
\text { hectáreas fiscales y la propuesta } \\
\text { peronista intentaba incluir } \\
\text { 730.00 hectáreas, mientras que } \\
\text { los radicales y } \\
\text { accionchaqueñistas señalaban } \\
\text { que el artículo no debían tener } \\
\text { especificaciones precisas porque } \\
\text { esa misión le tocaba a la } \\
\text { Legislatura. } \\
\text { Después de más de cuatro horas } \\
\text { de deliberaciones, que por } \\
\text { momentos tuvieron un alto } \\
\text { cesión de tierras. Entre los } \\
\text { voltaje político, los } \\
\text { conventencionalades que los apoyan } \\
\text { cuarto intermedio para aflojar } \\
\text { tensiones y debatir con mayor } \\
\text { tranquilidad una posibilidad de } \\
\text { acuerdo. En el diálogo }\end{array}$ & $\begin{array}{l}\text { Copete: “Una clásula } \\
\text { transitoria determina que en } \\
\text { no más de un año una } \\
\text { comisión técnica deberá } \\
\text { concretar los estudios que } \\
\text { establezcan cuál es la real } \\
\text { cantidad de tierra pública } \\
\text { que se entregará a los } \\
\text { aborígenes. El nuevo artículo } \\
\text { 34 reconoce la preexistencia } \\
\text { de los pueblos indígenas y su } \\
\text { identidad étnica y cultural. } \\
\text { Áspero debate de neto tinte } \\
\text { político y cargado de } \\
\text { acusaciones. El texto fue } \\
\text { aprobado por el voto de } \\
\text { radicales, } \\
\text { accionchaqueñistas y los } \\
\text { justicialistas Pedrini, Bosch } \\
\text { y Abraham" } \\
\text { (...) subtítulo de Nota: Una } \\
\text { transitoriedad en marcha } \\
\text { Tras el cuarto intermedio el } \\
\text { titular del Bloque Radical, } \\
\text { Carlos Guido Leunda, } \\
\text { explicitó que si el justicialismo } \\
\text { se avenía a votar el despacho } \\
\text { de mayoría en general, hacia el } \\
\text { compromiso de insertar en el }\end{array}$ \\
\hline
\end{tabular}




\begin{tabular}{|c|c|}
\hline 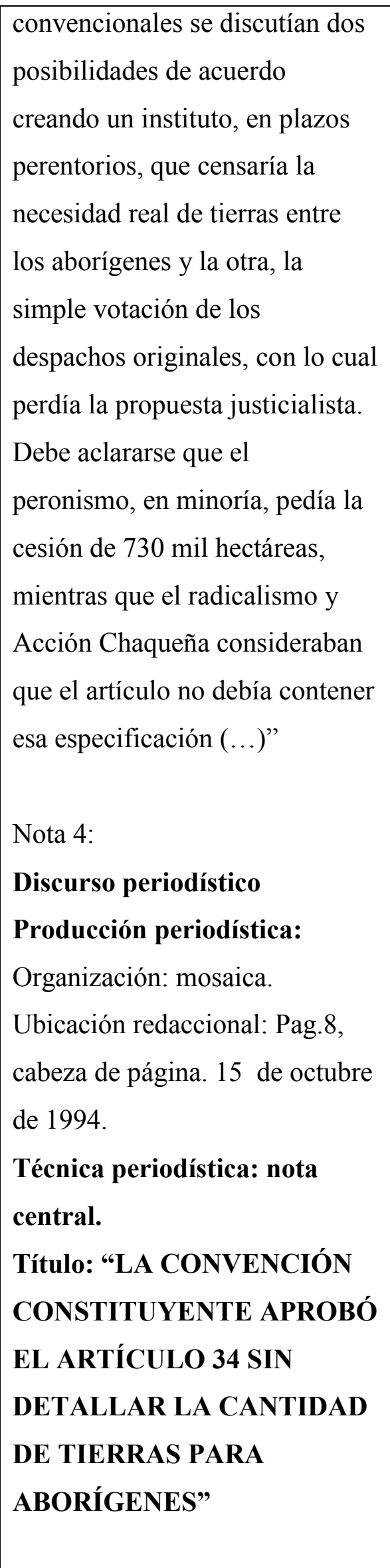 & 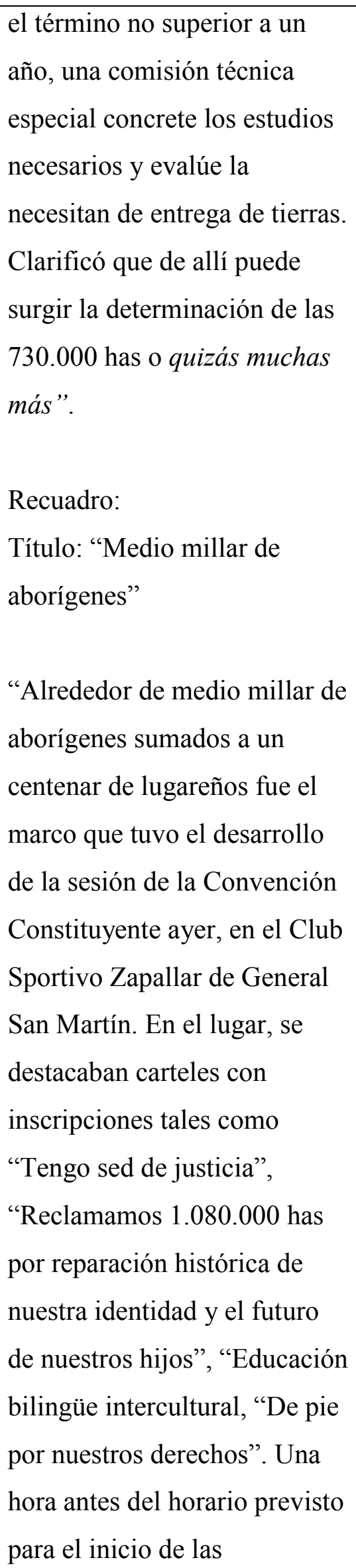 \\
\hline
\end{tabular}




\begin{tabular}{|c|c|}
\hline 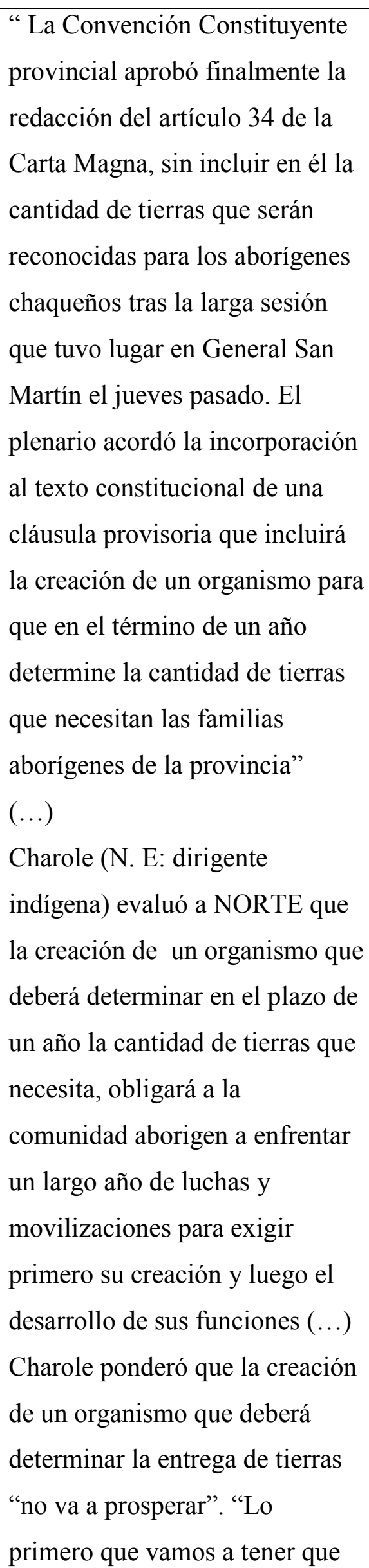 & $\begin{array}{l}\text { deliberaciones, un "blanco", } \\
\text { colocó carteles en lugares } \\
\text { sumamente visibles con las } \\
\text { siguientes inscripciones: } \\
\text { "Fuerza Chino (N de E: } \\
\text { Quiroga, convencional } \\
\text { peronista a favor de tierras } \\
\text { para indígenas), para apoyarlo } \\
\text { en defensa, recuperación y } \\
\text { reclamo de nuestras tierras". } \\
\text { Eran tres carteles similares, y } \\
\text { en cada uno supuestamente } \\
\text { firmaban tobas, wichís y } \\
\text { mocovíes. Obviamente a quien } \\
\text { hacían referencia era al Chino } \\
\text { Ireneo Quiroga”. }\end{array}$ \\
\hline
\end{tabular}




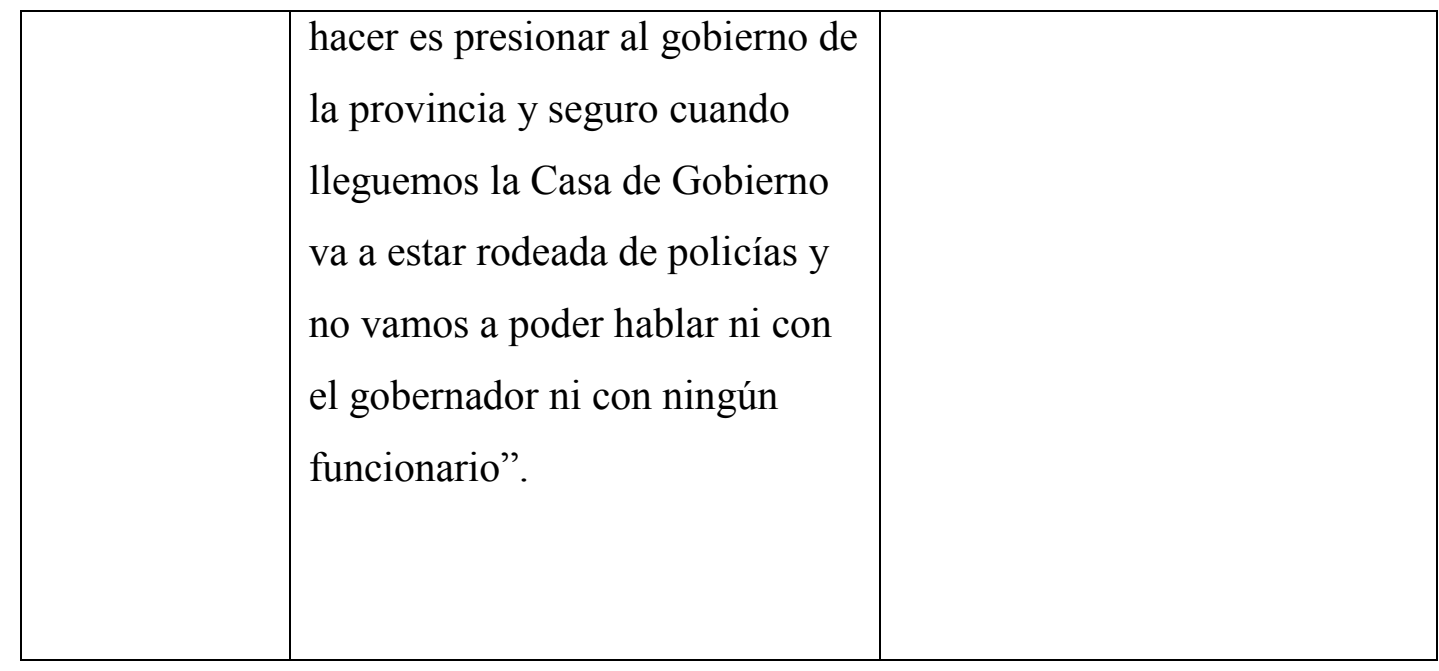

El nexo entre acontecimiento-fuente-noticia es central en la construcción del texto periodístico. Las fuentes son sujetos, documentos, de distinta índole de donde el periodista obtiene información $\mathrm{y}$ son utilizadas frecuentemente para recontextualizar los hechos, es decir situarlos en un determinado contexto, entendido el contexto como el conjunto de circunstancias que rodean o condicionan un hecho. Por ello hablamos de contexto social, político, cultural, económico, etc.

Las relaciones del periodista y de la organización informativa con las fuentes marcó el uso privilegiado de algunas fuentes sesga la información, es decir le impone un tipo de recorte según los intereses de la fuente.

Alsina menciona que el establecimiento de un acontecimiento público depende principalmente de tres factores: los promotores de noticias (las fuentes), los recolectores de noticias (los periodistas) y los consumidores de noticias (la audiencia).

Un promotor importante de noticias, una fuente privilegiada es el sistema político. En el caso estudiado, fue la única fuente consultada. Privilegiada porque los periodistas recurrieron a este tipo de fuente de manera permanente, sobre todo, para recontextualizar los acontecimientos.

El uso de este tipo de fuentes, en principio colmó una necesidad periodística que es la velocidad para la respuesta y la alta adaptación al contacto con la prensa.

Los representantes políticos respondieron a los requerimientos de la prensa de manera casi inmediata.

No ocurrió lo mismo con otros actores sociales. 
La opinión de una comunidad indígena sobre un tema, requiere de otra metodología de trabajo periodístico. Las notas publicadas fueron porque los dirigentes indígenas fueron a los medios.

Los medios y los periodistas, fueron fuentes legitimadas socialmente $\mathrm{y}$ representaron un status quo en el sistema capitalista y que a la vez refuerzó la legitimidad del trabajo periodístico.

Se mantiene el principio de autoridad y por otro lado, el principio de rol social, referido a que todo aquello que no tiene utilidad social queda excluido.

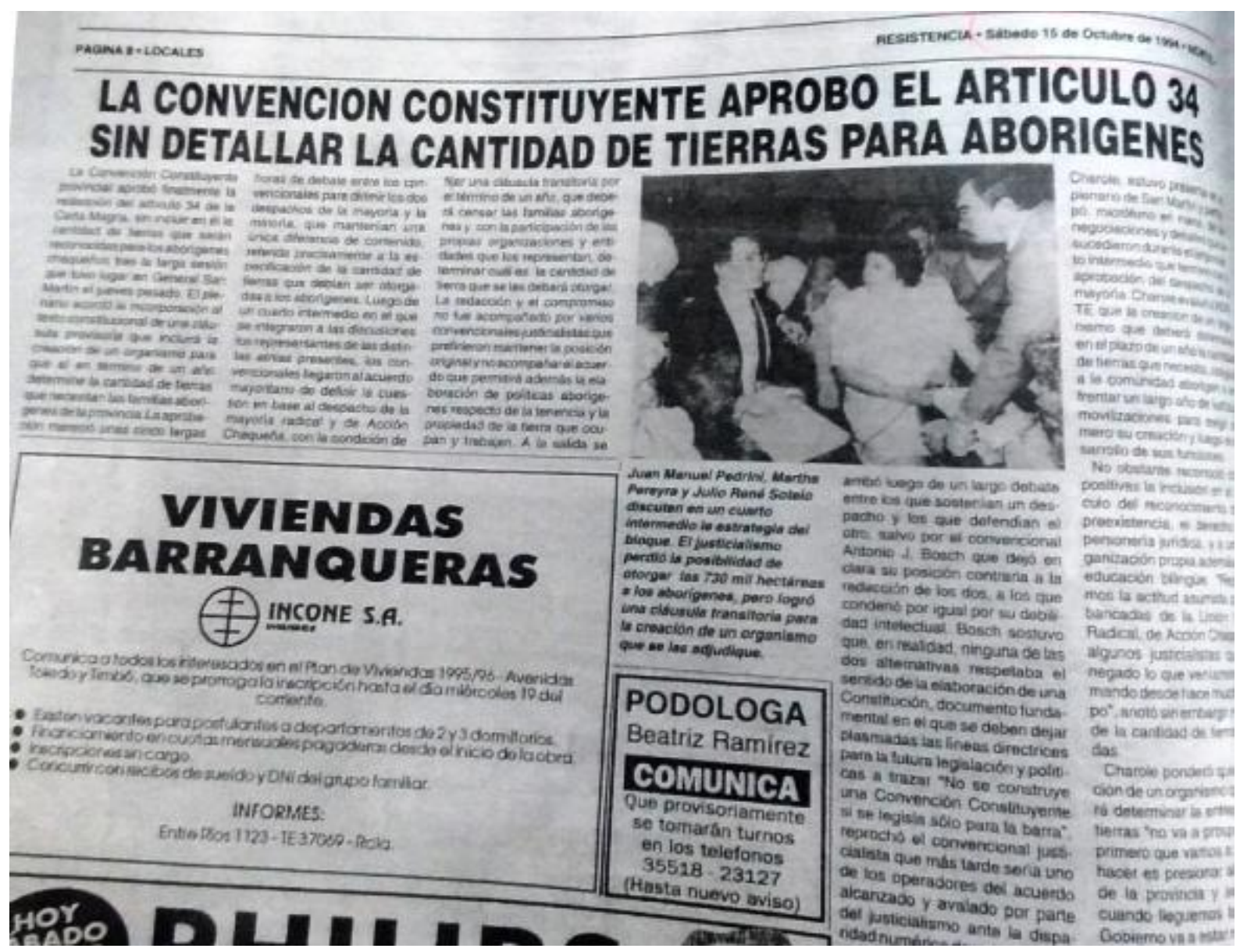




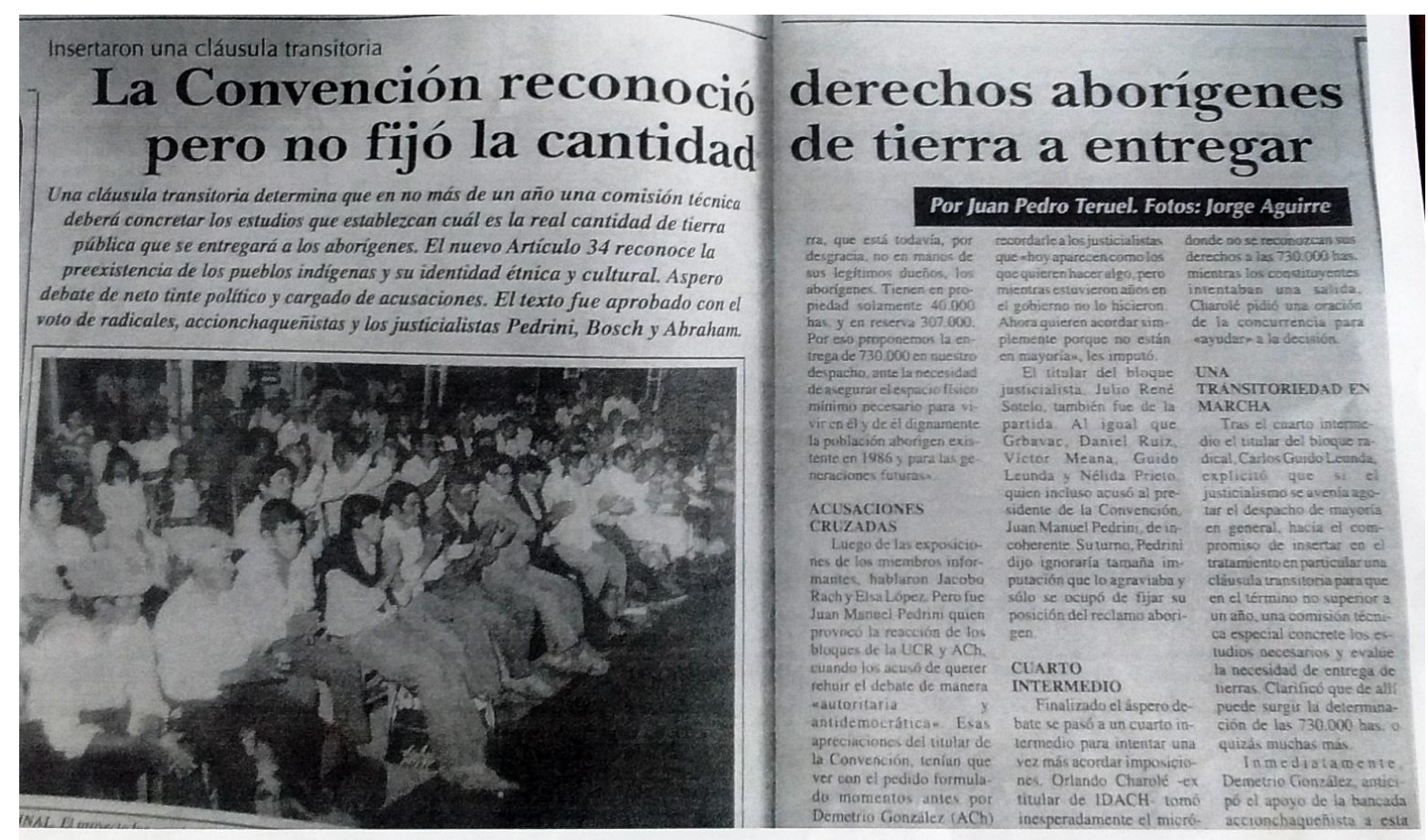




\section{j- Reflexiones analíticas originales a la que se arriba \\ La palabra fingida: Dis-curses parlamentario, periodístico, régimen de verdad y poder}

El discurso parlamentario constituye un entramado de relaciones de poder, plasmados en una normativa, producto de la relación de fuerza de una facción dominante.

Modelizado en la oratoria deliberativa, su forma jurídica sigue reglas orientadas a la administración del conflicto.

No es coercitivo, en el sentido de imponer un cuerpo sobre otro, ni es lucha, es un juego internalizado de reproducción del orden social dominante, donde los conflictos se interpretan en los escenarios dispuestos: Convención Constituyente, los actores tienen sus parlamentos asignados y la representación de la tragedia media, generando modos de conocer y comprender la realidad.

Los marcos cognitivos, siguiendo la definición de Serrano (2009), operan sobre el sentido del acontecer, para otorgar significado.

La categoría "Derechos indígenas" ingresó en la Constitución de 1957. Antes de ese momento histórico, el concepto "indígenas" existía en el Derecho Indiano como un recurso más de las Américas, por tanto sujeto a explotación y dominio del Conquistador.

La conceptualización de "Derechos indígenas" se generó ante el debate parlamentario sobre si se seguía sosteniendo el sistema de misiones y reducciones instaurado en la Conquista del Territorio Nacional del Chaco, en 1957.

Hasta ese momento, el sistema de creencias sociales sostenía que los indígenas debían contar con un gobierno (en el sentido de policity, de administración y dominio) por incapacidad de darse una forma organizativa ajustada a Derecho.

Por ello este trabajo de investigación distinguió una modelización discursiva sobre "Derechos indígenas". 
La modelización de 1957 terminó con los sistemas de reducción y misión, vigentes en la Provincia del Chaco desde la Conquista.

Sin embargo, sin recursos y sin territorio, no hay libertad, por tanto fue un ejercicio más de simulación. Así también, al iniciarse el cambio de estructura económica de la Provincia, abandonando el casi exclusivo cultivo del algodón, la necesidad de mano de obra barata y disponible también decaía.

Los pueblos indígenas tras la salida del sistema de reducciones y misiones, retomaron organizaciones clánicas, análogas a las previas a la Conquista y Colonización, pero sin autonomía económica por cambios profundos en el ecosistema de las grandes extensiones otrora boscosas del Chaco Gualamba.

Desde entonces, son refugiados en su propia tierra. El cambio operado desde la Conquista hasta la Colonización hacía imposible volver a una vida que ya no existía y donde el último recuerdo de las generaciones era la vida en las misiones o reducciones. No el pasado guerrero, que sigue operando en una capa profunda de la cultura, a través de mitos y leyendas.

La Convención de 1994, al reformar el artículo 34, montó otra tragedia vinculada a la idea de pluriculturalidad, entendida esta como una forma estética, a través de los pueblos indígenas como monumento histórico, como las figuras representadas en las artesanías, sin considerar la relación con el territorio.

Tierra es la representación moderna del territorio conquistado, en términos discusivos.

Por ello, en 1994, la discusión sobre la Tierra Pública (en manos del Estado Provincial) trataba de las relaciones de propiedad propias del capitalismo.

La asignación preferente, la discusión en particular sobre si era tierra que “ocupan” o "poseen”, evidenció una interpretación desde la forma jurídica. El movimiento fue: "Poseen en el sentido histórico que le dan los pueblos indígenas pero ocupan en el sentido legal”.

El ocupante debe "probar" que vive y explota determinado número de hectáreas para alcanzar el título de propiedad, según el Régimen de Tierras Públicas. No basta solo vivir, sino "explotar" la tierra, conforme a su inscripción en la epopeya 
colonizadora que originó el Estado Nación de 1853 y que se mantiene hasta el momento en que finaliza esta investigación en 2016.

El reconocimiento de "preexistencia de los pueblos indígenas", transcripto de igual modo que en la Reforma Constitucional Nacional de 1994, es un acto de demagogia en el sentido retórico, de simulación, de palabra fingida, recurriendo a Barthes.

Solo el contexto como recurso analítico posibilitó esta distinción entre la verdad proposicional y la pragmática de la mentira.

Las posiciones de las bancadas políticas, de los legisladores políticos siguieron ese game. Lo que caracteriza al poder en términos de Focault son sus complejos mecanismos inconscientes que operan como marcos cognitivos. No hubo alteración del régimen de verdad, sino clausura por vía de la oratoria deliberativa y reactualización del orden.

Estos juegos de táctica son los de los legisladores y los de estrategias los que corresponden al cuerpo social.

En tal sentido, el pueblo del Chaco, como cuerpo social, tendía al orden, no a un cambio revolucionario. Como sí lo hizo en 1951 y en 1957, puesto que fueron Convención que nombraron a la Provincia, primero como Presidente Perón, después como Provincia del Chaco. El ethos del pueblo que se constituye como colonizador del ancho territorio del Chaco Gualamba, lo divide en hectáreas, las distribuye "al que trabaja" y se legisla con un Régimen de Tierras, permite entender que la decisión de sus legisladores políticos no estaba fuera de la delegación otorgada por vía de democracia deliberativa.

En los discursos parlamentarios analizados, siempre los pueblos indígenas, fueron un "otro" frente a un "nosotros", no en sentido de alteridad sino como diferenciación simbólica propia de las formas del racismo, con operaciones discursivas más complejas, pero racismo al fin. En una de sus tantas conferencias sobre Racismo, Teun Van Dijk propone un ejercicio de análisis muy operativo: dice que si en cualquier texto encontramos un "ellos" y un "nosotros", el resto del contenido, así hable de "reconocimiento a "su" cultura, a "sus" formas organizativas" como el caso de la Convención de 1994, no deja de hablar de lo 
que no se oye: No hay igualdad jurídica, social, económica y política. No somos iguales a ellos.

Esta posición discursiva conserva plena actualidad en 2016, no solo en el Chaco, sino en las Américas, y en Europa, mientras se asiste al espectáculo de millones de refugiados, sin territorio.

El sentido de territorialidad de los pueblos indígenas no es considerado en la legislación porque no puede ser representado por la forma jurídica del derecho positivo.

La organización propuesta por los legisladores políticos para acceder a las tierras, por parte de los pueblos indígenas, fue la Asociación Civil. La "propiedad comunitaria" no existe en la legislación del derecho positivo. Existe la asociación de individuos que se organizan para acceder a la tierra, tanto en forma de cooperativas, que tiene tradición en la Provincia del Chaco, y la incorporada en 1994 para los grupos de indígenas organizados: la Asociación Civil. Creada para un fin determinado, como indica la ley de aplicación, por lo cual, si la tierra cambiase de uso, el Estado se reserva la potestad de recuperar la donación realizada.

La cadena metonímica donación- entrega de tierras, operó en la reproducción del discurso del orden.

Al finalizar esta investigación, en 2016, la aplicabilidad de la norma constitucional, operó por leyes y su aplicación mediante decretos fue lenta e incompleta.

El marco cognitivo de la epopeya colonizadora puso límites, no iba a entregarse el 40\% ni el 30\% de la tierra pública a los pueblos indígenas. ¿Qué sentido tendría entonces las largas y duras luchas para conquistarlas y después colonizarlas?

Por eso, la inclusión en el título de este trabajo de la esclarecedora definición de Barthes: la palabra fingida.

El motivo por el que se convocó a la Reforma Constitucional de 1994, en la Argentina fue la privatización de las empresas del Estado, como mandatarios del gobierno neoliberal. En la Provincia del Chaco, la voluntad del pueblo se 
manifestó en contra de esa privatización mediante un plebiscito previo a la Convención Constituyente. No fue un acto emancipatorio, sino un momento de discusión de facciones políticas, que involucraba también la discusión sobre el pase de la Caja Jubilatoria Provincial a la Nación, entonces, operó como parte de un mismo tema público.

No como posición en contra del gobierno neoliberal del presidente Carlos Menem, que tuvo un amplio apoyo en el Chaco, ni al gobierno de Acción Chaqueña, creado por el Coronel José David Ruiz Palacios, último gobernador de la dictadura de 1976. Fue un movimiento operado por el peronismo y el radicalismo en la Provincia, como alianza en vistas a desplazar del gobierno a la tercera fuerza política y retomar el escenario de polarización histórica entre el PJ y la UCR.

Una táctica de localía frente a un nuevo adversario político, con el que su concepción y reciente vida política, dificultaba acuerdos y consensos entre partidos políticos.

La prensa gráfica- en 1994, ante de la revolución tecnológica- tenía un poder en el orden de la designación de la agenda pública.

La relación entre sistema de prensa y sistema político constituyen una mediación social, en términos de Serrano. Operan sobre lo que se puede decir y lo que no, mediante la relación inclusión/exclusión de los temas en la agenda pública.

En ese sentido, se constató que la operación de exclusión y no tematización de la discusión sobre "Derechos indígenas", posibilito el mantenimiento del mito de la epopeya colonizadora.

No hubo cambios sobre la estructura del discurso social.

La denominada "sensibilización" sobre la situación de las "comunidades" indígenas, fue también palabra fingida.

Es interesante mencionar la justificación de Roberto Dromi: la privatización de las Empresas del Estado debía estar en la Constitución Nacional porque es el modo que no esté sujeta a los vaivenes políticos-electorales. Una Reforma Constitucional requiere de consenso, como el alcanzado con el Pacto de Olivos. La UCR y el PJ consensuaron la venta de las empresas estatales, más allá de los 
ejercicios retóricos demagógicos (en el estricto sentido aristotélico) escuchado y amplificado por el sistema de medios de comunicación.

Un argumento razonable.

El mismo fue utilizado por los pueblos indígenas: Si no se establece en la Constitución Provincial el número de hectáreas entregadas a las comunidades indígenas, no habrá leyes que garanticen su efectivo cumplimiento.

También un argumento razonable.

El primero fue aceptado, el segundo, no.

El sistema de medios de comunicación responde a una lógica capitalista, por tanto la sola exclusión del tema, fue suficiente.

\section{Aporte metodológico}

La tarea hermenéutica emprendida en este trabajo de investigación pudo realizarse considerando el Contexto como ámbito explicativo del discurso.

Interpretar el ambiente social, político y económico para entender el sentido del artículo 34 de la Constitución de 1957 y su Reforma en 1994.

Considero un recurso metodológico indispensable en el análisis crítico del discurso, como planeta Teun Van Dijk. Por lo cual, se recomienda su aplicación como herramienta metodológica, y a su vez, como constitutiva de un tipo de investigación: el análisis crítico del discurso.

Distintos estudios, entre los que se inscribe éste, mostraron que se sostiene como un tipo específico de investigación en la Comunicación.

Así también el análisis de dis-curses, los movimientos, games y estrategias, pudo realizarse con el método propuesto por Focault, la genealogía (o arqueología). Los pliegos del discurso remitían a pliegues anteriores y prospectivas que pudieron ser interpretadas con ese método. Por ello, el recorrido de los conceptos desde su generación, hasta su consolidación o emergencia, en un continumm. 


\section{La biopolítica}

Focault en sus últimos trabajos antes de su muerte, comienza a pensar el concepto de la biopolítica. El compromiso, el sentido ético de la vida del hombre en un mundo que avanza a su destrucción.

Hervé Fischer, en 2016, desde la ética retoma este concepto, asociado con el respeto a la alteridad, a las consecuencias del capitalismo en la humanidad y a la recuperación o reinvención de un sentido político asociado a la preservación de la vida.

El caso presentado forma parte de la historia de todos los pueblos vencidos del mundo occidental, a través de guerras y genocidios. Y también, por lo que se observa en 2016 del presente y el futuro.

El ejercicio de una intelectualidad crítica, formada y vital tiene un deber ético y es el sentido que encuentro al finalizar esta tesis.

La Comunicación, desde la transdisciplina, el estudio de las relaciones de poder y el reconocimiento de las formas constitutivas de los regímenes de verdad, se debe a sí misma una tarea que la implique con la vida social, en términos de preservación de la vida.

No son "otros" los refugiados, los sin tierra del mundo.

Alguna vez fueron un "nosotros".

En tanto no pensemos esta acción política, deber ético y propuesta emancipadora, la guerra seguirá siendo un capítulo de la historia, un segmento de los noticieros diarios, algo que no nos alcanzará nunca, protegidos por la certidumbre que las operaciones en los marcos cognitivos han sabido crear mediante las formas más sutiles de la complejidad del Poder, ejercido 


\section{Medios y mediación social, ciudadanía y democracia}

\section{Sobre la democracia de supervivencia}

Siguiendo a Nietzsche el problema de supervivencia no resuelto ha condicionado a la humanidad.

La democracia del siglo XXI no logra discutir más que los problemas de la supervivencia, que es la economía.

Siguiendo a Focault, en su concepto de biopolítica, se trata del poder del estado para hacer vivir de cualquier modo. Vida que se vive con más comodidad para compensar la falta de vida, fuera de la matriz de la supervivencia.

La esclavitud de la existencia no es percibida por los individuos y el valor moral de la vida es el trabajo. No se precisa Señor, lo hace la moral.

\section{El indio es vago porque no trabaja.}

Todo el tiempo este enunciado circuló en las argumentaciones.

No es trabajo cazar, no es trabajo pescar, hacer fuego, tolderías, recolectar frutos. Trabajo es un empleo (en el mejor de los casos), ser mano de obra productiva en la agricultura o las faenas del campo. O población incorporada a la asistencia social estatal.

En 2016, la violencia excede al Estado-Nación, cada vez más perdido en su deber de representación.

La acción de grupos de intereses en pugna busca la resolución por validación instrumental y no por vía ética, que en este sentido, es el camino colectivo.

Aquí los ideales de la modernidad, frustran o ya no existen. O hay que reiventarlos.

Todo nuestro continente está padeciendo esta fuerte agrupación de fuerzas y no encuentra vías colectivas de resolución.

Umberto Eco sostiene que "tener un enemigo es importante no solo para definir nuestra identidad, sino también para procurarnos un obstáculo con respecto al cual 
medir nuestro sistema de valores y mostrar; al encáralo, nuestro valor"( Eco: 2012)

La democracia es el metalenguaje de la retórica, y la génesis de la retórica es resolver la disputa de la propiedad y la posesión.

Otra vez subsistencia.

Presento la sospecha, que habrá que pensar una nueva praxis, agotados los intentos modernistas.

Los pueblos indígenas, sumidos por la democracia en muestras de "multiculturalidad, plurilinguismo, diversidad y expresión”, parece las máscaras de lo que fueron.

Y un objeto más de consumo.

Engranaje de la industria cultural. Insertados con violencia en la música étnica, el diseño étnico, y la producción que simula ser artesanal.

No quiero imaginar cuánto queda en su deseo y si queda, volver a montar a pelo un caballo, cazar y pescar los animales que no existen y dormir en su territorio.

Este es el preámbulo de la Constitución del Chaco y con él se clausuró y diseñó la concepción de la Provincia en 1994:

"Nos, los representantes del pueblo de la provincia del Chaco, reunidos en Convención Constituyentes reformadora, respetuosos de nuestra cultura fundante, con la finalidad de ratificar la exaltación de la dignidad de la persona humana, el pleno ejercicio de sus derechos; el respeto al pluralismo étnico, religioso e ideológico; reafirmar los valores de paz, libertada, justicia, igualdad y solidaridad; proteger la familia, la salud, el ambiente y los recursos naturales; asegurar el acceso y permanencia a la educación y a la cultura; establecer el derecho y el deber al trabajo; estimular la iniciativa privada y la producción, promoviendo una economía puesta al servicio del hombre con justicia social. Reorganizar los poderes del Estado y sus organismos de control a fin de garantizar su independencia, equidad y eficiencia; fortalecer un régimen municipal autónomo; afianzar la vigencia del orden constitucional; afirmar las instituciones republicanas y los derechos de la provincia en el concierto federal argentino, 
promoviendo su integración regional, nacional e internacional; para el definitivo establecimiento de una democracia pluralista y participativa y la consecución del bien común; invocando la protección de Dios, fuente de toda razón y justicia, sancionamos esta Constitución para todos los hombres que quieran habitar este suelo".

La democracia de supervivencia, no es una democracia de sentido social.

Es el pensamiento con el que cierro el presente trabajo, reflexionando sobre deber ético de la intelectualidad y el dominio de lo instrumental. 


\section{j- Bibliografía}

ALTSCHULL, J. y otros (1990) De Milton a Mac Luhan. Las ideas detrás del periodismo estadounidense. Publigrafics SA

BARRETO, Eduardo (2009). El sindicalismo en el Chaco en el período territorial 1884-1951. Resistencia, Chaco, Argentina. Grafic Center.

BARTHES, R. (2009) La aventura semiológica. España. Editorial Paidós.

BORRAT, Héctor y FONTCUBERTA. "Periódicos: sistemas complejos, narradores en interacción”. Mayo (2006). Buenos Aires, Argentina. La Crujía DÍAZ, E (2005) Posmodernidad. Buenos Aires. ArgentIna: Editoral Biblios.

DROMI, R, Carrió, E. y otros. (1995). Interpretando la Constitución. Madrid, España. Ediciones Ciudad Argentina

DWORKIN, R. (2014) Justicia para erizos. Buenos Aires, Argentina. Fondo de Cultura Económica

FOCAULT, Michel. (1980) La verdad y sus formas jurídicas. Barcelona, España. Editorial Gedisa. Obra completa

FOCAULT, Michel. (2002) Las palabras y las cosas. Buenos Aires, Argentina. Siglo XIX Editores.

FOUCAULT, M. (1992) Microfísica del Poder. Madrid. España. Ediciones La Pipeta

GALIANA, Enrique Eduardo (2007). Orden y Progreso. Provincias Fundadores y Nuevas Provincias. El modelo de crecimiento oligárquico. Corrientes, Argentina. Moglia Ediciones.

HABERMAS, J (1998) Facticidad y validez: sobre el derecho y el estado democrático de derecho en términos de teoría del discurso. España. Editorial Trotta

MURILLO, Susana. (1997). El discuso de Focault: Estado, locura y anormalidad en la construcción del individuo moderno. Buenos Aires, Argentina. Oficina de Publicaciones del CBC. Universidad de Buenos Aires 
O’ SUlliVAN, Tim, HARTLEY, John y otros. (1995) Conceptos claves en comunicación y estudios culturales. Buenos Aires, Argentina. Amorrortu editores RODRIGO ALSINA, Miquel. (1996)La construcción de la noticia. Barcelona.España. Paidós. $2^{\mathrm{a}}$ reimpresión

ROSSEAU, JJ. (2007). Discurso sobre el origen de la desigualdad entre los hombres. Barcelona, España. Ediciones Folio

ROTKER, Susana. (2005). La invención de la crónica. México. Fondo de Cultura Económica

SAN MARTINO DE DROMI, L. (1999) Pactos preconstitucionales. Madrid, España. Ciudad Argentina

SERRANO,Manuel M.(2008) Madrid, España. Ediciones Akal

TERÁN, O. (2008). Historia de las ideas en la Argentina. Bs As. Argentina. Editorial XXI

VAN DIJK, Teun.(1996) La noticia como discurso. Barcelona. España. Paidós Ibérica

VAN DIJK, Teun (2003) Racismo y discurso de las elites. Barcelona, España. Editorial Gedisa.

VAN DIJK, Teun (2013) Discurso y contexto. Un enfoque sociocognitivo. Barcelona, España. Editorial Gedisa.

VERSIONES TAQUIGRÁFICAS. Convención Constituyente de 1951 y 1957.

'VAN DIJK, Teun. Discurso y oralidad. www.discurses.org

ii DIARIO PÁGINA 12.(2016) ECONOMIA: MACRI FLEXIBILIZO POR DECRETO LOS CONTROLES PARA LA VENTA DE PROPIEDADES RURALES A EXTRANJEROS ${ }^{\text {ii }}$ 
Abren la tranquera para eludir la ley de tierras

La medida desarticuló una serie de exigencias que deben cumplir los inversores extranjeros para respetar la norma. Además, elimina controles que estaban a cargo de la UIF y la AFIP y facilita la venta de terrenos con espejos de agua.

Con la excusa de "facilitar y posibilitar las inversiones en el país" el gobierno de Mauricio Macri flexibilizó por decreto los controles dispuestos por la Ley de Tierras para la venta de propiedades rurales a extranjeros. La medida no modificó los límites para la extranjerización como el tope del 15 por ciento del territorio nacional y el máximo de 1000 hectáreas en zona núcleo o equivalente sino que desarticuló una serie de exigencias que deben cumplir los inversores extranjeros para adecuarse a la norma.

La nueva normativa les ofrece alternativas para eludir, a través de sencillas maniobras contables, las limitaciones y obligaciones dispuestas. El decreto que lleva la firma del presidente Mauricio Macri ofrece incluso recomendaciones/instrucciones para quienes están interesados en sortear los impedimentos. El texto eliminó también controles que estaban a cargo de la UIF y la AFIP, quitó sanciones para los intermediarios y pretende facilitar la venta de terrenos que incluyan espejos de agua. Las modificaciones, reconocen desde la Casa Rosada, constituyen la antesala para reemplazar el régimen de protección al dominio nacional sobre la propiedad, posesión y tenencia de la tierra en manos de extranjeros aprobado en diciembre de 2011 con una nueva y laxa legislación.

La ley vigente estableció el porcentaje del 15 por ciento como límite a la tenencia de tierras en manos de extranjeros. En la actualidad, el territorio controlado por inversores foráneos alcanza al 6 por ciento del total nacional, es decir unas 16 millones de hectáreas. La norma que hace cuatro años fue rechazada por los representantes de la alianza Cambiemos estableció además otras limitaciones y exigencias para los inversores extranjeros: impide que un mismo titular tenga a su nombre más de 1000 hectáreas equivalentes a la zona núcleo y bloquea la adquisición de terrenos que contengan cuerpos de agua de envergadura y permanentes. Asimismo exige que los interesados en comprar un terreno rural soliciten en el Registro Nacional de Tierras Rurales un certificado de habilitación que constate el cumplimiento de las distintas exigencias. Este es uno de los puntos que a partir de ahora podrán eludir. 
El subsecretario de Asuntos Registrales del Ministerio de Justicia de la Nación, Martín Borrelli, defendió ayer los cambios al sostener que la normativa "busca facilitar la llegada de inversiones productivas de capital extranjero en todo el país a través de la regulación de situaciones que no habían sido contempladas en la reglamentación de 2012". "Es mentira que se frenen las inversiones extranjeras con la ley. Desde su creación el Registro Nacional de Tierras Rurales otorgó los certificados de habilitación necesarios en el 93,6 por ciento de los casos solicitados pero parece que no era suficiente ya que frenaba la especulación inmobiliaria", indicó a Página/12 Florencia Gómez, ex titular del Registro. "Este decreto viola la Ley de Tierras. El gobierno de Macri desconoce las limitaciones de la ley para la venta de tierras", consideró la directora del Grupo de Apoyo Jurídico por el Acceso a la Tierra del Ceppas.

Una de las cuestionadas modificaciones a la ley que facilita el desembarco de extranjeros sorteando las restricciones es la exención de obtener la habilitación del Registro Nacional de Tierras Rurales en el caso de modificaciones accionarias que resulten en un control directo o indirecto por parte de personas jurídicas extranjeras. Los extranjeros que compren acciones deberán comunicarlo al Registro sin necesidad de requerir el certificado previo que controle el cumplimiento de las limitaciones legales. Pero, según advierte Gómez, brinda a quien supere los límites establecidos en la Ley 26.737, especialmente las 1000 hectáreas en zona núcleo o su equivalente, la posibilidad de "readecuarse" sin ningún tipo de sanción dentro de los 90 días, en caso de ser denunciado.

La "curiosidad" es que el nuevo decreto explica en su artículo 6 cómo deben hacer los inversores para sortear las restricciones vendiendo/transfiriendo a "personas jurídicas controladas o sujetas a control común con ellas, la titularidad del total o de aquella porción de tierras rurales que exceda el límite legal”. De este modo, podrían simular una adecuación a la ley a partir una transferencia a una empresa propia, lo que les garantiza mantener el control de las tierras.

El Decreto 820 fue publicado anteayer en el Boletín Oficial. La redacción de la normativa, según pudo saber este diario, contó con la activa colaboración de algunos de los estudios de abogados que protagonizan como intermediarios el desembarco de extranjeros en el mercado inmobiliario rural. Junto con el presidente, el texto lleva la firma del Jefe de Gabinete, Marcos Peña, el titular de 
Justicia, Germán Garavano, y el ministro de Interior y Obras Públicas, Rogelio Frigerio. Los cambios recibieron además el respaldo de la Cámara de Inmobiliarias Rurales (CAIR). Desde la entidad consideraron que facilitará la llegada de inversiones productivas de capital extranjero especialmente en la explotación de commodities como trigo, maíz, soja y girasol. "Era necesario que se flexibilizase", consideró el presidente de la CAIR, Javier Christensen, y consideró que "será necesario hacer más cambios". Por su parte, la Federación Agraria que históricamente impulsó la normativa cuestionó duramente al gobierno

iii VAN DIJK, Teun. LA CONTEXTUALIZACIÓN DEL DISCURSO PARLAMENTARIO: AZNAR, IRAQ Y LA PRAGMÁTICA DEL MENTIR'. www.discurses.org

iv Compendio de citas: PANELLA, Claudio (editor) La Prensa y peronismo. De la Revolución Libertadora a Carlos Menem. (Marzo 2005). EPC Medios, (2006).Sanucci, María Elena /editora "Prensa escrita: procesos, transformaciones y configuraciones. EPC Medios. 2004. Revista Trampas de la comunicación y la cultura "Historia y medios. La prensa escrita y la política en la Argentina del siglo XX". Editora Florencia Saintout.

`BRUNELLI, A; en PANELLA, Claudio (editor) La Prensa y peronismo. "El propósito de este trabajo es determinar la relación entre el ritual y los modos de construcción de la identidad en esas dos etapas del Diario Clarín (1946/49-1996-99) y determinar su relación con los modelos de Estado emergentes en cada período".

${ }^{v i}$ FONTCUBERTA, M. y BORRAT,H. Periódicos: sistemas complejos, narradores en interacción. (2006). Bs As, Argentina. La Crujía Ediciones.

${ }^{\text {vii }}$ VALDETTARO, Sandra y otros. Docentes-Investigadores del Departamento de Cs. de la Comunicación.(2006) Artículo publicado en "La Trama de la Comunicación", Anuario del Departamento de Ciencias de la Comunicación, Facultad de Ciencia Política y RR. II., Universidad Nacional de Rosario. Informe de Investigación. Proyecto: ESTRATEGIAS DE DELIMITACIÓN DE ESPACIOS DISCURSIVOS ESPECÍFICOS EN LA PRENSA ARGENTINA DE CIRCULACIÓN DIARIA viii DE LA FUENTE GARCÍA, Mario: La argumentación en el discurso periodístico sobre la inmigración. (2009) Tesis de doctorado, Universidad de León, www.dissoc.org/recursos/tesis/Tesis Garcia.pdf.

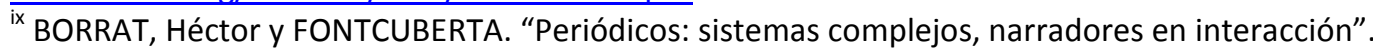
Mayo (2006). Buenos Aires, Argentina. La Crujía. Pág. 20

${ }^{x}$ ROTKER, Susana. (2005). La invención de la crónica. México. Fondo de Cultura Económica. Pág. 225.

${ }^{x i}$ VAN DIJK.La contextualización del discurso parlamentario 157 de las Cortes españolas". www.discurso y sociedad.org

xii RODRIGO ALSINA, Miquel. (1996)La construcción de la noticia. Barcelona.España. Paidós. 2ạ reimpresión Pp. 14.

xiii O' SULLIVAN, Tim, HARTLEY, John y otros. (1995) Conceptos claves en comunicación y estudios culturales. Buenos Aires, Argentina. Amorrortu editores.Pp 223-224.

${ }^{\text {xiv }}$ RODRIGO ALSINA, Miquel. (1996) La construcción de la noticia. Barcelona.España Paidós.. 2a a reimpresión 1996.P 91-92.

${ }^{x v}$ RODRIGO ALSINA, Miquel. (1996) La construcción de la noticia. Barcelona.España Paidós.. 2aa reimpresión 1996.P 95.

xvi VAN DIJK, Teun.(1996) La noticia como discurso. Barcelona. España. Paidós Ibérica.. P 70-71

xvii FOCUCAULT, Michel.(2002) Las palabras y las cosas. Buenos Aires, Argentina. Siglo XIX Editores. Pág. 87-88. 
xviii ALTSCHULL, J. y otros (1990) De Milton a Mac Luhan. Las ideas detrás del periodismo estadounidense. Publigrafics SA. Pp. 76.

${ }^{x i x}$ FOCAULT, Michel. (1980) La verdad y sus formas jurídicas. Barcelona, España. Editorial Gedisa. Obra completa.

${ }^{x x}$ ROSSEAU, JJ. (2007). Discurso sobre el origen de la desigualdad entre los hombres. Barcelona, España. Ediciones Folio. Obra completa

${ }^{x \times i}$ HABERMAS, J (1998) Facticidad y validez: sobre el derecho y el estado democrático de derecho en términos de teoría del discurso. España. Editorial Trotta

xxii DWORKIN, R. (2014) Justicia para erizos. Buenos Aires, Argentina. Fondo de Cultura

Económica. 460-463

xxiii MURILLO, Susana. (1997). El discuso de Focault: Estado, locura y anormalidad en la

construcción del individuo moderno. Buenos Aires, Argentina. Oficina de Publicaciones del CBC.

Universidad de Buenos Aires. Pp 68-82

${ }_{\text {xxiv }}$ FOUCAULT, M. (1992) Microfísica del Poder. Madrid. España. Ediciones La Pipeta. Pp 168-169

${ }^{x \times V}$ VAN DIJK, T.

http://www.discursos.org/oldarticles/Contextualizacion\%20de\%20discurso\%20parlamentario.pd

f.

$\bar{x} \times$ VEi SERRANO,Manuel M.(2008) Madrid, España. Ediciones Akal.Pp 75

xxvii FOUCAULT, M. (1992) Microfísica del Poder. Madrid. España. Ediciones La Pipeta. Pp 189

xxviii

xxix DROMI, R, Carrió, E. y otros. (1995). Interpretando la Constitución. Madrid, España. Ediciones Ciudad Argentina. Pp 62

${ }^{x \times x}$ DROMI, R y otros. (1995). Interpretando la Constitución. Madrid, España. Ediciones Ciudad

Argentina

${ }^{x \times x i}$ DROMI, R y otros. (1995). Interpretando la Constitución. Madrid, España. Ediciones Ciudad

Argentina. Pp 24-25

xxxii DROMI, R y otros. (1995). Interpretando la Constitución. Madrid, España. Ediciones Ciudad

Argentina. Pp 25

xxxiii. Interpretando la Constitución

http://catalogosuba.sisbi.uba.ar/vufind/Author/Home?author=Quiroga+Lavi\%C3\%A9\%2C+Humb erto

xxxiv SAN MARTINO DE DROMI, L. (1999) Pactos preconstitucionales. Madrid, España. Ciudad Argentina. Pp 15-22.

${ }^{x \times x v}$ DíAZ, E (2005) Posmodernidad. Buenos Aires. ArgentIna: Editoral Biblios. Obra completa.

xxxvi http://www.biblioteca.org.ar/libros/10068.pdf. Lucio V. Mansilla. Una excursión a los indios

ranqueles.

xxxvii BARTHES, R. (2009) La aventura semiológica. España. Editorial Paidós. Pp 119-120

xxviii GALIANA, Enrique Eduardo (2007). Orden y Progreso. Provincias Fundadores y Nuevas

Provincias. El modelo de crecimiento oligárquico. Corrientes, Argentina. Moglia Ediciones. Pp 19.

xxxix IBID. Pp 22.

X'́́BID. Pp 24.

xi íBID. Pp 27-28

xlii íBID Pp 31

xliii í́BID. Pp 32

xliv íBID Pp 34

${ }^{x \mid v}$ íBID. Pp 34

xlvi BARRETO, Eduardo (2009). El sindicalismo en el Chaco en el período territorial 1884-1951. Resistencia, Chaco, Argentina. Grafic Center Pp 87-89.

xlvii BARRETO, Eduardo (2009). El sindicalismo en el Chaco en el período territorial 1884-1951.

Resistencia, Chaco, Argentina. Grafic Center Pp 197-198.

xlviii http://www.idcp.jursoc.unlp.edu.ar/index.php/doctrina/103-el-desarrollo-delconstitucionalismo-en-america-del-norte. NUÑEZ, Roberto. Instituto de Derecho Constitucional y Político. Facultad de Ciencias Jurídicas y Sociales. Universidad Nacional de la Plata (2016)

${ }^{x i l i x}$ www.usoderazón.com. DAMBORENEA, RICARDO GARCÍA. DICCIONARIO DE FALACIAS. Pp 2

' www.usoderazón.com. DAMBORENEA, RICARDO GARCÍA. DICCIONARIO DE FALACIAS. Pp 10-11 
li TERÁN, O. (2008). Historia de las ideas en la Argentina. Bs As. Argentina. Editorial XXI. Pp 61-72

lii SAN MARTINO DE DROMI, L. (1999) Pactos preconstitucionales. Madrid, España. Ciudad Argentina. PP 363-366

liii SAN MARTINO DE DROMI, L. (1999) Pactos preconstitucionales. Madrid, España. Ciudad Argentina. PP 371-373.

liv Honorable Convención Constituyente. Provincia del Chaco. Diario de Sesiones. (1957). Pp 381382.

${ }^{\text {Iv }}$ Honorable Convención Constituyente. Provincia del Chaco. Diario de Sesiones. (1957). Pp 382383

Ivi SANTIBÁÑEZ Y. y MARAFIOTI, R. (Editores). (2008). Buenos Aires. Argentina. Biblios. Pp 73. 